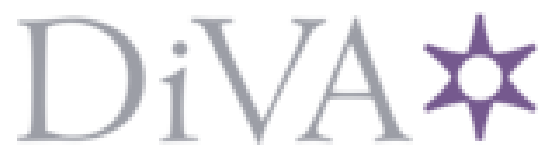

http://www.diva-portal.org

This is the published version of a paper published in Cochrane Database of Systematic Reviews.

Citation for the original published paper (version of record):

Gaitonde, R., Oxman, A D., Okebukola, P O., Rada, G. (2016)

Interventions to reduce corruption in the health sector.

Cochrane Database of Systematic Reviews, (8): CD008856

https://doi.org/10.1002/14651858.CD008856.pub2

Access to the published version may require subscription.

N.B. When citing this work, cite the original published paper.

Permanent link to this version:

http://urn.kb.se/resolve?urn=urn:nbn:se:umu:diva-129770 


\section{(E) Cochrane Library}

Cochrane Database of Systematic Reviews

\section{Interventions to reduce corruption in the health sector (Review)}

Gaitonde R, Oxman AD, Okebukola PO, Rada G

Gaitonde R, Oxman AD, Okebukola PO, Rada G.

Interventions to reduce corruption in the health sector.

Cochrane Database of Systematic Reviews 2016, Issue 8. Art. No.: CD008856.

DOI: 10.1002/14651858.CD008856.pub2.

www.cochranelibrary.com 
TABLE OF CONTENTS

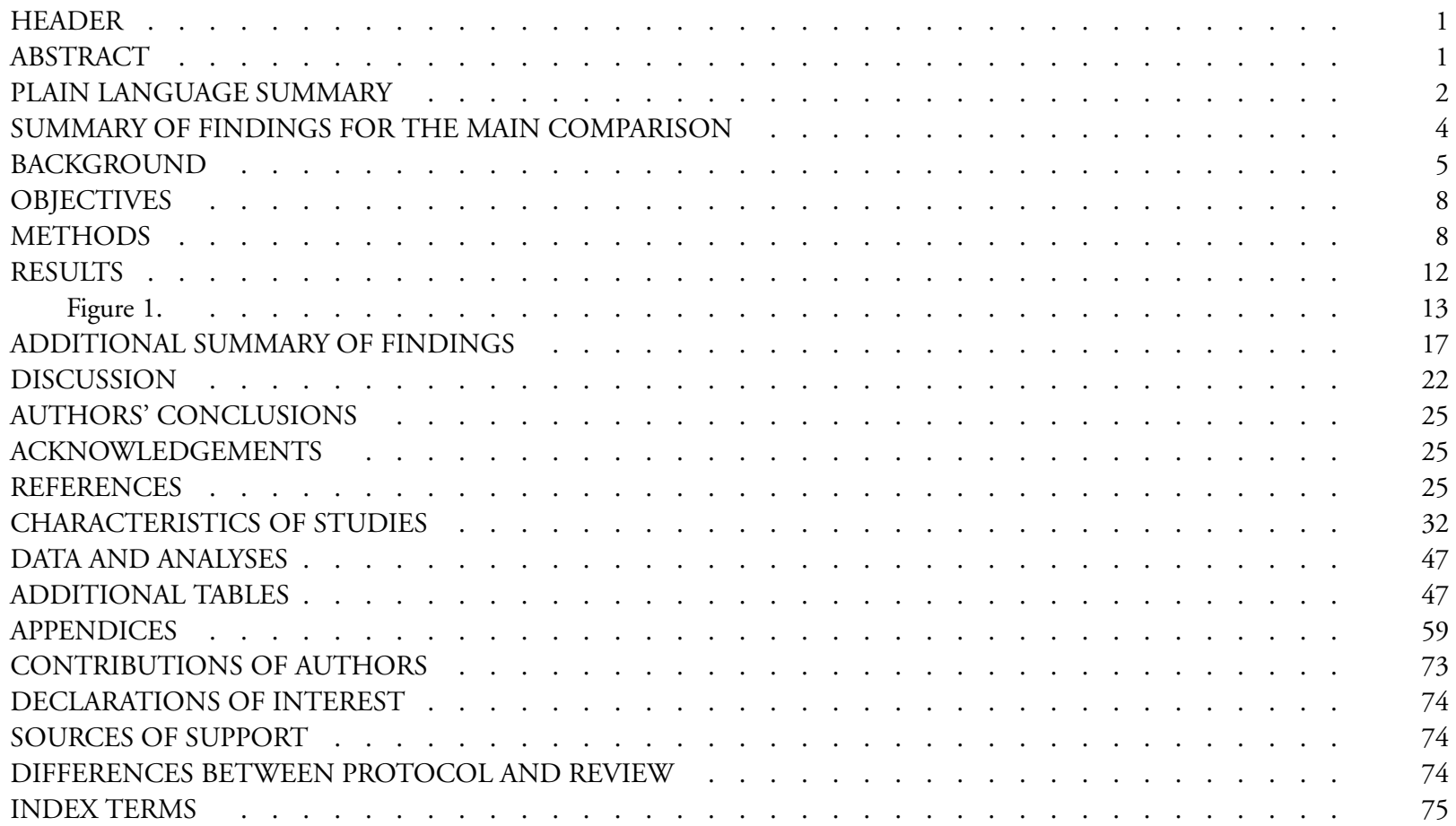

Interventions to reduce corruption in the health sector (Review)

Copyright (c) 2016 The Authors. Cochrane Database of Systematic Reviews published by John Wiley \& Sons, Ltd. on behalf of The

Cochran Collaboration. 


\title{
[Intervention Review] \\ Interventions to reduce corruption in the health sector
}

\author{
Rakhal Gaitonde ${ }^{1,2}$, Andrew D Oxman ${ }^{3}$, Peter O Okebukola ${ }^{4}$, Gabriel Rada ${ }^{5}$ \\ ${ }^{1}$ Department of Public Health and Clinical Medicine, Umeå University, Umeå, Sweden. ${ }^{2}$ Centre of Technology and Policy, Indian \\ Institute of Technology - Madras, Chennai, India. ${ }^{3}$ Norwegian Institute of Public Health, Oslo, Norway. ${ }^{4}$ Department of Health Policy \\ and Management, Johns Hopkins Bloomberg School of Public Health, Baltimore, Maryland, USA. ${ }^{5}$ Department of Internal Medicine \\ and Evidence-Based Healthcare Program, Faculty of Medicine, Pontificia Universidad Católica de Chile, Santiago, Chile \\ Contact address: Rakhal Gaitonde, Department of Public Health and Clinical Medicine, Umeå University, Umeå, Sweden. \\ rakhal.gaitonde@gmail.com.
}

Editorial group: Cochrane Effective Practice and Organisation of Care Group.

Publication status and date: New, published in Issue 8, 2016.

Review content assessed as up-to-date: 6 June 2016.

Citation: Gaitonde R, Oxman AD, Okebukola PO, Rada G. Interventions to reduce corruption in the health sector. Cochrane Database of Systematic Reviews 2016, Issue 8. Art. No.: CD008856. DOI: 10.1002/14651858.CD008856.pub2.

Copyright (C) 2016 The Authors. Cochrane Database of Systematic Reviews published by John Wiley \& Sons, Ltd. on behalf of The Cochrane Collaboration. This is an open access article under the terms of the Creative Commons Attribution-Non-Commercial Licence, which permits use, distribution and reproduction in any medium, provided the original work is properly cited and is not used for commercial purposes.

\section{A B S T R A C T}

\section{Background}

Corruption is the abuse or complicity in abuse, of public or private position, power or authority to benefit oneself, a group, an organisation or others close to oneself; where the benefits may be financial, material or non-material. It is wide-spread in the health sector and represents a major problem.

\section{Objectives}

Our primary objective was to systematically summarise empirical evidence of the effects of strategies to reduce corruption in the health sector. Our secondary objective was to describe the range of strategies that have been tried and to guide future evaluations of promising strategies for which there is insufficient evidence.

\section{Search methods}

We searched 14 electronic databases up to January 2014, including: CENTRAL; MEDLINE; EMBASE; sociological, economic, political and other health databases; Human Resources Abstracts up to November 2010; Euroethics up to August 2015; and PubMed alerts from January 2014 to June 2016. We searched another 23 websites and online databases for grey literature up to August 2015, including the World Bank, the International Monetary Fund, the U4 Anti-Corruption Resource Centre, Transparency International, healthcare anti-fraud association websites and trial registries. We conducted citation searches in Science Citation Index and Google Scholar, and searched PubMed for related articles up to August 2015. We contacted corruption researchers in December 2015, and screened reference lists of articles up to May 2016.

\section{Selection criteria}

For the primary analysis, we included randomised trials, non-randomised trials, interrupted time series studies and controlled beforeafter studies that evaluated the effects of an intervention to reduce corruption in the health sector. For the secondary analysis, we included case studies that clearly described an intervention to reduce corruption in the health sector, addressed either our primary or secondary objective, and stated the methods that the study authors used to collect and analyse data.

Interventions to reduce corruption in the health sector (Review)

Copyright ( 2016 The Authors. Cochrane Database of Systematic Reviews published by John Wiley \& Sons, Ltd. on behalf of The

Cochrane Collaboration. 


\section{Data collection and analysis}

One review author extracted data from the included studies and a second review author checked the extracted data against the reports of the included studies. We undertook a structured synthesis of the findings. We constructed a results table and 'Summaries of findings' tables. We used the Grading of Recommendations Assessment, Development and Evaluation (GRADE) approach to assess the certainty of the evidence.

\section{Main results}

No studies met the inclusion criteria of the primary analysis. We included nine studies that met the inclusion criteria for the secondary analysis.

One study found that a package of interventions coordinated by the US Department of Health and Human Services and Department of Justice recovered a large amount of money and resulted in hundreds of new cases and convictions each year (high certainty of the evidence). Another study from the USA found that establishment of an independent agency to investigate and enforce efforts against overbilling might lead to a small reduction in overbilling, but the certainty of this evidence was very low. A third study from India suggested that the impacts of coordinated efforts to reduce corruption through increased detection and enforcement are dependent on continued political support and that they can be limited by a dysfunctional judicial system (very low certainty of the evidence).

One study in South Korea and two in the USA evaluated increased efforts to investigate and punish corruption in clinics and hospitals without establishing an independent agency to coordinate these efforts. It is unclear whether these were effective because the evidence is of very low certainty.

One study from Kyrgyzstan suggested that increased transparency and accountability for co-payments together with reduction of incentives for demanding informal payments may reduce informal payments (low certainty of the evidence).

One study from Germany suggested that guidelines that prohibit hospital doctors from accepting any form of benefits from the pharmaceutical industry may improve doctors' attitudes about the influence of pharmaceutical companies on their choice of medicines (low certainty of the evidence).

A study in the USA, evaluated the effects of introducing a law that required pharmaceutical companies to report the gifts they gave to healthcare workers. Another study in the USA evaluated the effects of a variety of internal control mechanisms used by community health centres to stop corruption. The effects of these strategies is unclear because the evidence was of very low certainty.

\section{Authors' conclusions}

There is a paucity of evidence regarding how best to reduce corruption. Promising interventions include improvements in the detection and punishment of corruption, especially efforts that are coordinated by an independent agency. Other promising interventions include guidelines that prohibit doctors from accepting benefits from the pharmaceutical industry, internal control practices in community health centres, and increased transparency and accountability for co-payments combined with reduced incentives for informal payments. The extent to which increased transparency alone reduces corruption is uncertain. There is a need to monitor and evaluate the impacts of all interventions to reduce corruption, including their potential adverse effects.

\section{PLAIN LANGUAGE SUMMARY}

\section{Interventions to reduce corruption in the health sector}

\section{What is the aim of this review?}

The aim of this Cochrane review is to assess the effectiveness of strategies to reduce corruption in the health sector. Cochrane researchers searched for all potentially relevant studies, and found nine studies that met their criteria.

\section{Key messages}

The review suggests that some strategies to fight corruption in the health sector can have an effect on corruption. These strategies include the use of independent agencies to investigate and punish corruption, telling healthcare workers that they are not allowed to accept payments from pharmaceutical companies, ensuring that information about healthcare prices is clear and accessible to the public together with increasing healthcare worker salaries. However, the certainty of this evidence varies. We need more high-quality studies that assess the effects of these and other strategies.

Interventions to reduce corruption in the health sector (Review) 


\section{What was studied in the review?}

Corruption can occur in any area of the health sector, and happens when people abuse their own position to benefit themselves, their organisation, or other people close to them. It can take many forms, including bribes, theft, or giving incorrect or inaccurate information deliberately.

Healthcare officials, for instance, may steal healthcare funds, hospital administrators may change patient records to increase hospital payments, doctors may accept bribes from pharmaceutical companies in exchange for using their products, and patients may try to bribe hospital staff to avoid treatment queues.

Corruption affects the health sector in many ways. It can take money away from healthcare, lead to poorer quality care and make access to healthcare unfair, and often affects poor people the hardest.

\section{What are the main results of the review?}

The review authors included nine relevant studies that used different strategies to stop corruption.

- In a study from the USA, efforts to investigate and punish corruption in the health sector were also increased. An independent agency at the national level coordinated these efforts, which led to convictions and the recovery of large amounts of money (high certainty evidence). These efforts may also have led to substantial savings to the government (low certainty evidence). In another study from the USA establishment of an independent agency to investigate and enforce efforts against overbilling was established, but the effects of these efforts are unclear because the evidence was of very low certainty. In India, there were efforts to stop corruption through the appointment of an ombudsman in one state. However, the effect of this strategy is unclear because the evidence was of very low certainty.

- In one study in South Korea and two in the USA, efforts to investigate and punish corruption in clinics and hospitals were increased, without establishing an independent agency. However, it is unclear whether these were effective because the evidence is of very low certainty.

- In a study in Kyrgyzstan, the government carried out a number of strategies, including giving patients and the public information about how much they should be paying, and increasing healthcare workers' salaries. This study shows that these strategies may have led to fewer patients giving their doctors informal payments (low certainty evidence).

- In a study in Germany, hospital doctors were given guidelines telling them that they were not allowed to accept money or gifts from pharmaceutical companies. The study suggests that this may have changed doctors' attitudes about the influence of pharmaceutical companies on their choice of medicines (low certainty evidence).

- In one study in the USA, the authorities introduced a law that required pharmaceutical companies to report the gifts they gave to healthcare workers. In another USA-based study, community health centres attempted to stop corruption using a variety of internal control mechanisms. However, the effect of these strategies is unclear because the evidence was of very low certainty.

We don't know what the effects of these strategies have on healthcare or people's health, or if these strategies had any harmful effects. This is because the studies only assessed the effects of the strategies on corruption and the use of resources, or because the evidence was of very low certainty.

\section{How up to date is this review?}

The review authors searched for studies that had been published up to 06 June 2016.

Interventions to reduce corruption in the health sector (Review) 
SUMMARY OF FINDINGS FOR THE MAIN COMPARISON [Explanation]

\begin{tabular}{|c|c|c|c|c|}
\hline \multirow{2}{*}{$\begin{array}{l}\text { Types of interven- } \\
\text { tions }{ }^{*}\end{array}$} & \multicolumn{4}{|l|}{ Impacts } \\
\hline & Corruption & Adverse effects & Resource use & $\begin{array}{l}\text { Healthcare and health out- } \\
\text { comes }\end{array}$ \\
\hline $\begin{array}{l}\text { Disseminate informa- } \\
\text { tion } \\
\text { Information campaigns } \\
\text { aimed at changing } \\
\text { knowledge, attitudes or } \\
\text { beliefs about corrup- } \\
\text { tion; or developing } \\
\text { skills to address cor- } \\
\text { ruption }\end{array}$ & $\begin{array}{l}\oplus \oplus \ominus \ominus \\
\text { (attitudes) }^{1}\end{array}$ & 0 & [2] & 0 \\
\hline $\begin{array}{l}\text { Improve detection and } \\
\text { enforcement } \\
\text { Improve detection and } \\
\text { punishment of corrup- } \\
\text { tion }\end{array}$ & $\begin{array}{l}\oplus \ominus \theta \ominus \\
\text { (overbilling })^{3} \\
{[2,4,5,6]}\end{array}$ & 0 & $\begin{array}{l}\bigoplus_{\ominus \ominus \ominus} \\
\text { (healthcare expenditures) }{ }^{7} \\
{[2]}\end{array}$ & $\begin{array}{l}? \oplus \ominus \ominus \ominus \\
\text { (utilisation and health out- } \\
\text { comes) })^{8}\end{array}$ \\
\hline $\begin{array}{l}\text { Establish an indepen- } \\
\text { dent agency* } \\
\text { Establish an anti-cor- } \\
\text { ruption agency to coor- } \\
\text { dinate anti-corruption } \\
\text { activities }\end{array}$ & $\begin{array}{l}\oplus \oplus \oplus \oplus \\
\text { (convictions) }^{2} \\
\oplus \ominus \ominus \ominus \\
\text { (convictions) }^{4} \\
\oplus \ominus \ominus \ominus \\
\text { (complaints) }^{4} \\
\oplus \ominus \ominus \ominus \\
\text { (overbilling) }^{5}\end{array}$ & 0 & $\begin{array}{l}\oplus \oplus \oplus \oplus \\
\text { (recovered funds) }^{2} \\
\oplus \oplus \ominus \ominus \\
\text { (savings) }^{2}\end{array}$ & 0 \\
\hline $\begin{array}{l}\text { Increase transparency } \\
\text { and accountability } \\
\text { Increase transparency } \\
\text { and accountability in } \\
\text { decision-making pro- } \\
\text { cesses; e.g. by increas- } \\
\text { ing stakeholder partic- } \\
\text { ipation or mandatory } \\
\text { documentation of deci- } \\
\text { sions that is open to ac- } \\
\text { cess }\end{array}$ & $\begin{array}{l}\oplus \ominus \theta \ominus \\
\text { (internal control prac- } \text { tices) } \\
\oplus_{\ominus \ominus \ominus} \\
\text { (informal payments) }^{8} \\
\oplus \ominus \ominus \ominus \\
\text { (pharmaceutical com- }_{\text {pany gifts) }}{ }^{9}\end{array}$ & 0 & 0 & 0 \\
\hline $\begin{array}{l}\text { Decrease discretion } \\
\text { Decrease discretion of } \\
\text { those who have power }\end{array}$ & [6] & 0 & 0 & 0 \\
\hline
\end{tabular}

Interventions to reduce corruption in the health sector (Review)

Copyright $\odot 2016$ The Authors. Cochrane Database of Systematic Reviews published by John Wiley \& Sons, Ltd. on behalf of The 


\begin{tabular}{llll}
\hline $\begin{array}{l}\text { Reduce incentives } \\
\text { Remove or reduce in- }\end{array}$ & 0 & 0 & 0 \\
$\begin{array}{l}\text { centives or factors that } \\
\text { motivate corrupt be- } \\
\text { haviours }\end{array}$ & 0 & 0 & 0 \\
\hline $\begin{array}{l}\text { Reduce monopolies } \\
\text { Increase the range of } \\
\text { choice of alternative } \\
\text { suppliers or providers } \\
\text { of specific services }\end{array}$ & & \\
\hline
\end{tabular}

* Some studies evaluated combinations of more than 1 type of intervention. The effect estimates for these interventions are shown in what we considered to be the main type of intervention and a footnote in square brackets is shown for other types of interventions that were combined with that intervention. Establishment of an independent agency was combined with improvement of detection and enforcement in all studies that evaluated an intervention that entailed establishment of an independent agency. Improvement of detection and enforcement was also combined with improvement of detection and enforcement in 2 of the 3 studies that evaluated increased transparency and accountability

Key: = a desirable effect; = little or no effect; ? = an uncertain effect; $0=$ no included studies

$\oplus \oplus \oplus \oplus=$ high certainty of the evidence (because of a very strong association). The research provides a very good indication of the likely effect. The likelihood that the effect will be substantially different ${ }^{\dagger}$ is low.

$\oplus \oplus \oplus_{\ominus}=$ moderate certainty of the evidence. The research provides a good indication of the likely effect. The likelihood that the effect will be substantially different ${ }^{\dagger}$ is moderate.

$\oplus \oplus_{\ominus} \ominus$ = low certainty of the evidence. The research provides some indication of the likely effect. However, the likelihood that it will be substantially different ${ }^{\dagger}$ is high.

$\oplus_{\ominus \theta \theta}=$ very low certainty of the evidence. The research does not provide a reliable indication of the likely effect. The likelihood that the effect will be substantially different ${ }^{\dagger}$ is very high.

†Substantially different: a large enough difference that it might affect a decision

${ }^{1}$ Guidelines prohibiting doctors from accepting benefits from the pharmaceutical industry (Germany 2008).

${ }^{2} \mathrm{~A}$ coordinated package of interventions (USA 2005-2014).

${ }^{3}$ Onsite investigation for false and fraudulent claims and penalties for wrong doers (South Korea 2007).

${ }^{4}$ Appointment of an ombudsman and a vigilance director (India 2001-2005).

${ }^{5}$ Coordination of federal, state and local enforcement efforts against healthcare fraud (USA 1993-2001).

${ }^{6}$ Internal control practices in community health centres (USA 2006).

${ }^{7}$ Increased expenditure on fraud enforcement efforts by (USA 1994-1998).

${ }^{8}$ Increased transparency and accountability for co-payments and reduced incentives for informal payments (Kyrgyzstan 2001-2010).

${ }^{9}$ Restrictions on pharmaceutical company gifts (USA 2002-2006).

B A C K G R O U N D

\section{Description of the condition}

\section{Defining corruption}

There is no one comprehensive and universally agreed upon definition of corruption. Some organisations, such as the United $\mathrm{Na}$ tions, do not even try to define corruption, but simply list a set of practices that may be deemed corrupt. In Table 1 we summarise some of the key definitions in the literature. Although this is not a

Interventions to reduce corruption in the health sector (Review) 
comprehensive list, we believe it captures the key elements of most of the commonly used definitions. The following key dimensions can be identified across these definitions of corruption.

- The person who abuses power may directly commit the abuse or may be complicit in its abuse.

- It can be by people who are either in private or public positions of power.

- A position of power or authority may be either entrusted by the formal systems of governance or by social/cultural systems.

- The abuse may be for the benefit of oneself, a group, an organisation, a party, or others close to those who abuse their power.

- Benefits can be financial, material or non-material (such as furtherance of political or professional ambition).

- The abuse violates the rights of other individuals or groups.

Based on these dimensions we have developed the following definition: "The abuse or complicity in abuse, of public or private position, power or authority to benefit oneself, a group, an organisation or others close to oneself; where the benefits may be financial, material or non-material." Corruption always violates the rights of other individuals or groups, but this may be indirectly rather than directly, and those rights might not be formally established. Factors like greed, unchecked decision-making power, financial arrangements within the health system, or the general state of governance in a society have been shown to contribute to the extent of corruption (Ensor 2002; Rose-Ackerman 2004; Vian 2002; Vian 2008). In some situations, for example in settings where salaries are inadequate to pay for basic necessities, corruption has been considered a 'coping mechanism' and has been described as 'survival corruption' (U4 2006). While not attempting to go into the moral dimensions of these nuances, it is important to realise that corruption in such differing situations will have very different incentive structures and rationalisations, and thus interventions will have different outcomes in both the short term and the long term in these differing settings.

Other terms that are closely related to corruption are fraud ("intentional deception or misrepresentation made by a person or an entity, with the knowledge that the deception could result in some kinds of unauthorised benefits to that person or entity") and abuse (which may be used to describe problematic behavior which is not necessarily fraudulent or corrupt) (Rashidian 2012). In general, corruption is defined more broadly than fraud, since some types of corruption are not fraud (e.g. bribes). Informal payments are commonly considered to be a form of corruption, but not consistently (Chereche 2013), and they may not be fraud or corruption (e.g. gifts given out of gratitude or financial support for the benefit of the health facility and other patients).

\section{Corruption in the health sector}

The health sector is characterised by the fact that a large amount of public funds, including donor funds in low- and middle-in- come countries (LMICs) are used and an increasingly significant proportion of these funds are transferred to private parties. The health sector also plays a vital role in the overall well-being of a community. Moreover, people who use the health system are in a vulnerable state (as patients) and often are not fully aware of their rights. There is a wide variety of actors engaged in the health sector, including policymakers, healthcare providers, health professionals and suppliers. All these factors make the health sector highly vulnerable to corruption (Savedoff 2006).

While it is very difficult to quantify corruption in the health sector due to the number of causes, cases and grey areas, estimates from around the world point to a large amount of corruption. For example in the USA, the Federal Bureau of Investigation (FBI) estimates that $3 \%$ to $10 \%$ of the Medicaid and Medicare budgets is lost to overpayment, or an estimated USD 35 to 117 billion yearly (CMS 2015; FBI 2011). In the USA, the Attorney General declared healthcare fraud the "number two crime problem in America” after violent crime (Sparrow 2008). Similarly, research from Cambodia in 2005 estimated that $5 \%$ to $10 \%$ of the health budget disappears before it is paid from the Ministry of Finance to the Ministry of Health (Hussmann 2011). Similarly, in one estimate $56 \%$ of health expenditure in the Russian Federation consisted of informal payments (Dyer 2006). Gee and colleagues estimate that $7.29 \%$ of global healthcare expenditures is lost to fraud (and error) yearly, or an estimated USD 415 billion, based on the World Health Organization's (WHO) 2008 estimate of annual global healthcare expenditures (Gee 2011).

Corruption affects the performance of the health system adversely and increases inequities. It is crucial to study ways of reducing corruption, not only to reduce the loss of resources, but also to address the adverse effects of corruption on the health system and society. As noted by the Global Corruption Report in 2006, although money lost directly to corruption is the most obvious and immediate cost, the negative effects of corruption in terms of quality of government and the well-being of a population are longer term. The potential gains from fighting corruption - such as more and better healthcare, stronger judiciaries and legitimate politics - are immense (TI 2006). Multivariable analyses of the association between measures of corruption and measures of health across countries have consistently found that more corruption is associated with worse health outcomes (Factor 2015; Hanf 2011; Lewis 2006; Lio 2015; Muldoon 2011; Nadpara 2015; Pinzón-Flórez 2015). For example, Hanf and colleagues estimated that approximately 140,000 annual children deaths could be directly attributed to corruption, based on the association that they found (Hanf 2011). Similarly, Lio 2015 found that a lower level of corruption or a better control of corruption in a country can lead to longer life expectancy, a lower infant mortality rate and a lower under-five mortality rate for citizens. They did not find an association between corruption and individual diseases, including human immunodeficiency virus (HIV) prevalence and tuberculosis incidence. Factor 2015 found that higher corruption is associated with lower levels

Interventions to reduce corruption in the health sector (Review) 
of health expenditure as a percentage of gross domestic product (GDP) per capita, as well as with poorer health outcomes, which provides a conceptual link between corruption and health outcomes.

Different types of corruption in the health sector can be classified in a number of different ways. For example, Ensor 2002 divides corrupt practices into bribes, theft, bureaucratic corruption and misinformation. Vian 2008 has identified the following areas where corruption may occur.

- Construction and rehabilitation of health facilities.

- Purchase of equipment and supplies, including drugs.

- Distribution of drugs and supplies in service delivery.

- Regulation of quality in products, services, facilities and professionals.

- Education of health professionals.

- Medical research.

- Provision of services by medical personnel and other health workers.

Corruption in the health sector can also be categorised based on different types of interaction, such as interactions between patients and health professionals, between payers and hospitals, and between hospitals and suppliers. Based on these and other ways of categorising different types of corruption, we have developed the matrix shown in Table 2, using the types of behaviour and the types of interactions as the two axes for the matrix.

\section{Types of corruption excluded from this review}

The focus of this Cochrane review is on interventions to reduce corruption committed by people engaged in overseeing, managing or providing healthcare services. Other groups of people not directly involved in the provision of services can adversely affect the use of healthcare resources and health outcomes, and may provide indirect evidence of the impacts of interventions to reduce corruption among the key actors in healthcare systems. However, we excluded these other types of corruption for pragmatic reasons (the implications for identifying and synthesising relevant studies) and conceptual reasons (corrupt behaviours and the impacts of interventions to reduce them may differ substantially for other actors). We also excluded interventions to reduce corruption of some forms by people within the health system for the same reasons; these include abuse in medical and health policy research and abuses in medical training and placements. We excluded the diversion of patients from public to private practice, which is addressed in another Cochrane Effective Practice and Organisation of Care (EPOC) review (Kiwanuka 2014).

\section{Effects of corruption in the health sector}

The effects of corruption in the health sector have been described in a number of different ways and at different levels. These include general effects, effects on the healthcare system and effects on health outcomes.

\section{General systemic effects}

Corruption might produce more unequal distribution of income (Li 2000). Corruption also might inhibit the improvement of services and the ability of reform to improve a range of services (Ensor 2004). Corruption increases the cost of key public services and might limit the access for those least able to pay (Falkingham 2004; Rose-Ackerman 2004; Szende 2006).

\section{Health system effects}

Within the health sector, corruption might favour the construction of hospitals and purchase of expensive, high technology equipment over primary healthcare programmes, such as immunisation and family planning (U4 2006). As resources are drained from health budgets through embezzlement and procurement fraud, less funding is available to pay salaries and fund operations and maintenance, which might lead to demotivated staff, lower quality of care and reduced service availability and use (Lindelow 2006). Corruption in the form of informal payments for care might reduce access to services, especially for the poor, and cause delays in care-seeking behavior (Lewis 2000).

\section{Health outcomes}

Corruption has been associated with lower immunisation rates, delays in vaccination and failure to treat patients, lower use of public health clinics, reduced satisfaction with care and increased waiting times (Azfar 2005a; Azfar 2005b). Corruption is negatively associated with health indicators such as infant and child mortality (estimated to be almost twice as high in countries with high corruption than in countries with low corruption), after adjusting for income, female education, health spending and level of urbanisation (Gupta 2002). These effects are based on associations found in studies using regression analyses on cross-sectional data sets. Given possible confounding and the fact that causation cannot be confidently attributed, the effects of corruption and the magnitude of these effects are uncertain. However, it is likely that large-scale corruption has important impacts on access to and the quality of health services, and that these in turn affect health outcomes.

\section{Description of the intervention}

Anti-corruption interventions can be categorised in different ways (Batory 2012; Graycar 2012; Johnsøn 2012; Lewis 2006; Rose-Ackerman 2012; Vian 2008). In Table 3 we have summarised different types of interventions that could be used to reduce corruption, examples of specific interventions and how these interventions might work. Interventions are listed roughly in order 
from least restrictive or intense (dissemination of information) to most (establishment of an independent agency to coordinate and lead anti-corruption activities). Potential interventions to reduce corruption include the following.

- Information campaigns aimed at changing knowledge, attitudes or beliefs about corruption; or developing skills to address corruption.

- Reduction of monopolies (increasing competition) so as to increase the ability to choose from different providers of a service or product.

- Removal or reduction of incentives or factors that motivate corrupt behaviours.

- Increase in transparency and accountability in decisionmaking processes.

- Decrease in discretion of those who have power.

- Improvement of detection and punishment of corruption.

- Establishment of an anti-corruption agency to coordinate anti-corruption activities.

\section{Why it is important to do this review}

Corruption in the health sector is pervasive. This reduces the effectiveness, efficiency and equity of health services, which in turn has adverse effects on health outcomes and development. A wide range of strategies to reduce corruption has been described in the literature, but these have uncertain impacts, may have adverse effects and may require substantial investments of resources (Batory 2012; Graycar 2012; Johnsøn 2012; Lewis 2006; Rose-Ackerman 2012; Vian 2008).

\section{O B JECT IVES}

\section{Primary objective}

To systematically summarise empirical evidence of the effects of strategies to reduce corruption in the health sector.

\section{Secondary objective}

To describe the range of strategies that have been tried and to guide future evaluations of promising strategies for which there is insufficient evidence.

\section{Criteria for considering studies for this review}

\section{Types of studies}

Although randomised studies provide the best possible evidence of the effects of interventions to reduce corruption, there are practical hindrances to the use of randomisation (Johnsøn 2013; Peisakhin 2011). For our primary objective, we searched for interrupted time series (ITS) studies with at least three time points before and after the start of the intervention, and controlled before-and-after (CBA) studies with at least two sites in each comparison group, as well as for randomised and non-randomised trials (Cochrane EPOC 2013a).

In addition we included both descriptive and evaluative case studies as part of our secondary objective with the aim of identifying the following.

- The range of strategies that have been tried and described.

- Potentially promising strategies that have been used and warrant further evaluation.

- Strategies that have been used and appear unlikely to warrant further evaluation (e.g. because they were found not to be feasible or acceptable).

- Potential adverse consequences of strategies.

For a case study to be included, the intervention must have been described clearly, the questions that the case study addressed had to be stated explicitly and be relevant to at least one of the objectives of the secondary analysis, and the methods used to collect and analyse data had to be stated. We included case studies that used qualitative as well as quantitative methods of analysis.

We planned to systematically review this broad range of study designs, including studies that provide little or no reliable evidence regarding effects, in the first version of this review, but not in updates of the review, which will focus only on impact evaluations.

\section{Types of participants}

Anyone working in or with influence on the health sector, including government regulators, payers, suppliers, providers and patients.

\section{Types of interventions}

Any intervention that might reduce corruption in the health sector (see Table 3), including the following.

- Dissemination of information: information campaigns aimed at changing knowledge, attitudes or beliefs about corruption; or skills to address corruption.

- Reduced monopolies: increase the ability to choose from different providers of a service or product.

- Reduced incentives: remove or reduce incentives or factors that motivate corrupt behaviours.

\section{METHODS}

Interventions to reduce corruption in the health sector (Review) 
- Increased transparency and accountability: increase transparency and accountability in decision-making processes; e.g. by increasing stakeholder participation or mandatory documentation of decisions that is open to access.

- Decreased discretion: decrease the discretion of those who have power.

- Improved detection and enforcement: improve the detection and punishment of corruption.

- Establishment of an independent agency: establish an anticorruption agency to coordinate anti-corruption activity.

We excluded studies of interventions targeted at absenteeism, which were the focus of another Cochrane review (Kiwanuka 2014).

\section{Types of outcome measures}

\section{Main outcomes}

To be included in the primary analysis a study had to report at least one measure of corruption; for example, using household and public expenditure surveys, control systems, perception surveys or qualitative data (e.g. in depth interviews), adverse consequences of an anti-corruption intervention, or resource use.

\section{Other outcomes}

We included other outcomes that focused on potential consequences of corruption, including the following.

- Health and health inequities.

- Appropriateness or quality of care.

- Distribution of care and inequity in access to care.

- Utilisation of health care.

- Financial consequences for patients.

- Individual rights.

- Patient satisfaction.

- Patient measures of quality of care.

- Attitudes towards government.

\section{Search methods for identification of studies}

\section{Electronic searches}

We searched the following databases without time or language restrictions.

- Cochrane Central Register of Controlled Trials (CENTRAL), 2014, Issue 1, part of The Cochrane Library. www.cochranelibrary.com (including the Cochrane Effective Practice and Organisation of Care (EPOC) Group Specialised Register) (searched 29 January 2014).
- MEDLINE In-Process \& Other Non-Indexed Citations and MEDLINE 1946 to Present, Ovid (searched 29 January 2014) and PubMed alerts (between January 2014 and 6 June 2016).

- EMBASE 1980 to 2014 Week 4, Ovid (searched 30 January 2014).

- Global Health 1973 to present, CABDirect (searched 31 January 2014).

- Sociological Abstract 1952 to current, ProQuest (searched 31 January 2014).

- Social Services Abstracts 1979 to current, ProQuest (searched 31 January 2014).

- Worldwide Political Science Abstracts 1975 to current, ProQuest (searched 31 January 2014).

- EconLit 1969 to current, ProQuest (searched 31 January 2014).

- ABI/Inform Global 1923 to current, ProQuest (searched 31 January 2014).

- International Political Science Abstracts (IPSA) 1951 to present, EbscoHost (searched 03 February 2014).

- LILACS, VHL (searched 03 February 2014).

- WHOLIS, Global Health Library (searched 3 February 2014).

- Human Resources Abstracts 2001 to 2005, CSA (searched 25 November 2010).

- Euroethics: http://www.ethicsweb.eu/ (searched 27 August 2015).

- International Bibliography of the Social Sciences, ProQuest (searched 1 March 14).

We have reported all search strategies we used in Appendix 1.

\section{Searching other resources}

\section{Grey literature}

We searched the following sources.

- Open Grey: http://www.opengrey.eu/ (searched 7 February 2014).

- New York Academy of Medicine Library: http:// nyam.waldo.kohalibrary.com/cgi-bin/koha/opac-search.pl (searched 6 February 2014).

- World Bank Documents \& Reports: http:// documents.worldbank.org/curated/en/docadvancesearch (searched 24 August 2015).

- World Bank e-library: http://elibrary.worldbank.org/ (searched 7 February 2014).

- World Bank Governance \& Anti-Corruption: http:// web.worldbank.org/WBSITE/EXTERNAL/WBI/ EXTWBIGOVANTCOR/ 0, contentMDK:20673872 menuPK:1740557 -pagePK:64168445 piPK:64168 (searched 7 February 2014).

Interventions to reduce corruption in the health sector (Review) 
- IMF publications: http://www.imf.org/external/ publications/pubindadv.htm (searched 27 August 2015).

- IMF eLibrary: http://www.elibrary.imf.org/ (searched 27 August 2015).

- EU Cordis: http://cordis.europa.eu/ (searched 24 August 2015).

- U4 Anti-corruption Resource Centre: http://www.u4.no/ (searched 24 August 2015).

- Transparency International: http://www.transparency.org/ (searched 24 August 2015).

- UNDP Oslo Governance Centre: http://www.undp.org/ content/undp/en/home/ourwork/democraticgovernance/ oslo_governance_centre/ (searched 24.08.2015).

- Poverty Action Lab: http://www.povertyactionlab.org/ (searched 10 February 2014).

- International Initiative for Impact Evaluation (3iE) http:// www.3ieimpact.org/ (searched 10 February 2014).

- International Political Science Abstracts (IPSA) 1951 to

present (EBSCO) (searched 3 February 2014).

- SSRN (Social Science Research Network eLibrary

Database): http://papers.ssrn.com/sol3/

DisplayAbstractSearch.cfm (searched 24 August 2015).

- CHR. Michelsen Institute: http://www.cmi.no/ (searched 26 August 2015).

- The National Health Care Anti-Fraud Association: http:// www.nhcaa.org/ (searched 26 August 2015).

- The Canadian Health Care Anti-Fraud Association: http:// www.chcaa.org/ (searched 26 August 2015).

- New study on corruption in the healthcare sector

(European Commision - 10 December 2013): http:// ec.europa.eu/dgs/home-affairs/what-is-new/news/news/2013/

20131219_01_en.htm (searched 26 August 2015).

- The Health Insurance Counter Fraud Group: http:// www.hicfg.com/ (searched 26 August 2015).

- European Healthcare Fraud \& Corruption Network: http:/ /www.ehfcn.org/ (searched 26 August 2015).

\section{Trials registries}

- World Health Organization (WHO) International Clinical Trials Registry Platform (ICTRP): http://www.who.int/ictrp/en/ (searched 10 February 2014).

- ClinicalTrials.gov: http://clinicaltrials.gov/ (searched 10 February 2014).

\section{Other sources}

We also performed the following.

- We searched the Cochrane Database of Systematic Reviews (CDSR) (part of the Cochrane Library www.thecochranelibrary.com) the Database of Abstracts of Reviews of Effects (DARE www.crd.york.ac.uk/CRDWeb/) and
PDQ-Evidence (http://www.pdq-evidence.org) for related systematic reviews.

- We screened the reference lists of key background documents and relevant studies.

- We contacted corruption researchers, including the authors of key background documents and included studies.

- We conducted a cited reference searches for all included studies in:

- Science Citation Index Expanded (SCI-EXPANDED), ISI Web of Knowledge: (searched 25 August 2015);

- Google Scholar: https://scholar.google.com/ (searched 24 August 2015).

- We conducted a search of PubMed related articles (searched 24 August 2015).

The Cochrane Effective Practice and Organisation of Care (EPOC) Information Specialist, Marit Johansen, in consultation with the authors, developed the search strategies.

We have reported all search strategies that we used in Appendix 1.

\section{Data collection and analysis}

\section{Selection of studies}

The review authors divided the responsibility for screening the search results and assessment of the full-text articles of retrieved studies between the review author team. Two review authors independently read the titles and abstracts that resulted from the initial database searches (in January 2014) and eliminated any obviously irrelevant studies. One review author screened the subsequent titles and abstracts that resulted from subsequent searches. We retrieved the full-text articles of potentially relevant studies. Two review authors assessed each retrieved study using the selection criteria described above. We included studies that met the inclusion criteria. We resolved disagreements by consensus among all the review authors.

\section{Data extraction and management}

We extracted the following data from each included study.

\section{Settings and targeted populations}

We extracted information on the characteristics of the people at whom the intervention was targeted and characteristics of the settings in which the intervention was implemented, including: the location of the study, classification of countries based on World Bank classifications (http://web.worldbank.org/WBSITE/ EXTERNAL/DATASTATISTICS/

0, contentMDK:20420458 - menuPK:64133156 pagePK:64133150 piPK:6413 the Corruption

Interventions to reduce corruption in the health sector (Review) 
Perceptions Index for the countries (http://www.transparency.org/ policy_research/surveys_indices/cpi), types of provider organisations, types of individual providers, types of health service users, and key characteristics of the setting and targeted population reported by the investigators.

\section{Interventions}

We extracted data on the characteristics of the interventions, including: categorisation of the type of intervention (Table 3), the type of corruption at which the intervention was targeted (Table 2), who initiated the intervention, who implemented or enforced the intervention and how, who monitored implementation or enforcement of the intervention and how, what funding was needed to implement or enforce and monitor the intervention and the source of funding, the timing of the intervention in relationship to when outcomes were measured, and an assessment of whether sufficient details are provided that it would be possible to replicate the intervention in another setting.

\section{Outcome measures}

We recorded the primary outcome measures reported by the investigators, which of the main and other outcomes specified under the 'Types of outcome measures' section were measured, and any other outcomes that the included study measured.

\section{Results}

We recorded the adjusted and unadjusted changes in each included outcome measure in each comparison group as reported by the investigators, measures of effect reported by the investigators and the analytic method used, measures of precision (confidence intervals, $\mathrm{P}$ values, standard deviations, etc.) as reported by the investigators, whether and if so how adjustment was made for clustering in estimates of precision.

\section{Process or qualitative evaluations}

When an included study reported process or qualitative evaluations, we recorded the design and data collection methods used, the main findings and the interpretation of the findings by the study investigators.

\section{Case studies}

For included case studies we collected the following information: the design and data collection methods used, the main findings and the interpretation of the findings by the study investigators.

\section{Risk of bias}

Two review authors extracted data independently from each included study using a standard data-extraction form. We resolved discrepancies by checking against the study report and, if needed, discussion with the other review authors.

\section{Assessment of risk of bias in included studies}

For case studies that met the inclusion criteria we described in the 'Types of studies' section, we used the following criteria to assess the risk of bias. For each criterion we judged whether it was met, was unclear or was not met, and included the basis for our judgements in a 'Risk of bias' table.

- The basis for case selection was appropriate.

- The time span of the study was long enough to address the core issues fairly.

- The methods for data collection were appropriate for the purpose of the study.

- The sources of information were appropriate for the purpose of the study.

- The methods used to analyse the data were appropriate for the purpose of the study.

- The methods used to identify explanatory factors were appropriate for the purpose of the study.

- The linkages are transparent between the data that were reported and inferences.

In addition we assessed whether the study authors provided adequate information to allow us to judge the applicability of the findings to other settings.

\section{Measures of treatment effect}

We recorded and reported measures of effect in the same way that the study investigators reported them. We did not standardise measures of effect to allow for comparisons across studies, since between-study comparisons were irrelevant; i.e. although the included studies targeted some interventions at the same types of corruption (listed under the 'Data extraction and management' section), the populations, settings, interventions, comparisons, outcomes and study designs were so heterogeneous that comparisons between studies were irrelevant.

\section{Data synthesis}

We describe the methods we intended to use for our primary analysis in the 'Differences between protocol and review' section, since we did not find any studies that met our inclusion criteria for the primary analysis.

For the secondary analysis we undertook a structured synthesis (Cochrane EPOC 2013b), and we used an approach that we did not describe in the protocol (Gaitonde 2010). We first prepared a results table (Table 4) with the following information: the type 
of intervention, reported effects, the type of study and our interpretation of the study findings. We extracted one included study, (USA 2005-2014, from annual reports for the past 10 years. We summarised the key findings from these reports in a separate table (Table 5),

In the results table (Table 4), we categorised the interventions using the categories we specified in the protocol (Table 3). We then grouped the results into four categories that emerged from our analysis of the results: dissemination of information, improvement of detection and enforcement, establishment of an independent agency and improvement of detection and enforcement, and increased transparency and accountability. For each category of interventions, we assessed the certainty of the evidence for each reported outcome (Appendix 2) and prepared 'Summary of findings' tables (Summary of findings 2; Summary of findings 3; Summary of findings 4; Summary of findings 5). We used the Cochrane EPOC worksheets to prepare the 'Summary of findings' tables using the Grading of Recommendations Assessment, Development and Evaluation (GRADE) approach (Cochrane EPOC 2013c). Finally, we placed the findings of the studies included in our secondary analysis in a framework based on the categories of interventions described in the results table (Table 4) and the categories of outcomes listed under the 'Types of outcome measures' section. This table, Summary of findings for the main comparison, includes the direction of effect, the certainty of the evidence and the outcome that was measured for each effect estimate that we found, as well as indicated categories of interventions and outcomes for which the included studies did not provide any evidence. In this table, we included some effect estimates in more than one cell, since some interventions combined more than one strategy to reduce corruption.

\section{RE S U L T S}

\section{Description of studies}

\section{Results of the search}

The searches retrieved 10,157 references, which we subsequently screened by title and abstract. We assessed 66 full-text papers for inclusion in this review. We excluded 45 of those articles for the reasons we have described in the 'Characteristics of excluded studies' table. We found no studies that fulfilled our criteria for the primary analysis. We included nine case studies described in 21 papers that fulfilled our criteria for secondary analysis (see the 'Characteristics of included studies' table). Four studies identified by a corruption researcher or a PubMed update after the review was submitted are awaiting classification (Di Tella 2003; Dowd 2016; Randall 2005; Samuel 2015).

We have summarised the study selection process in Figure 1. 
Figure I. Study flow diagram.

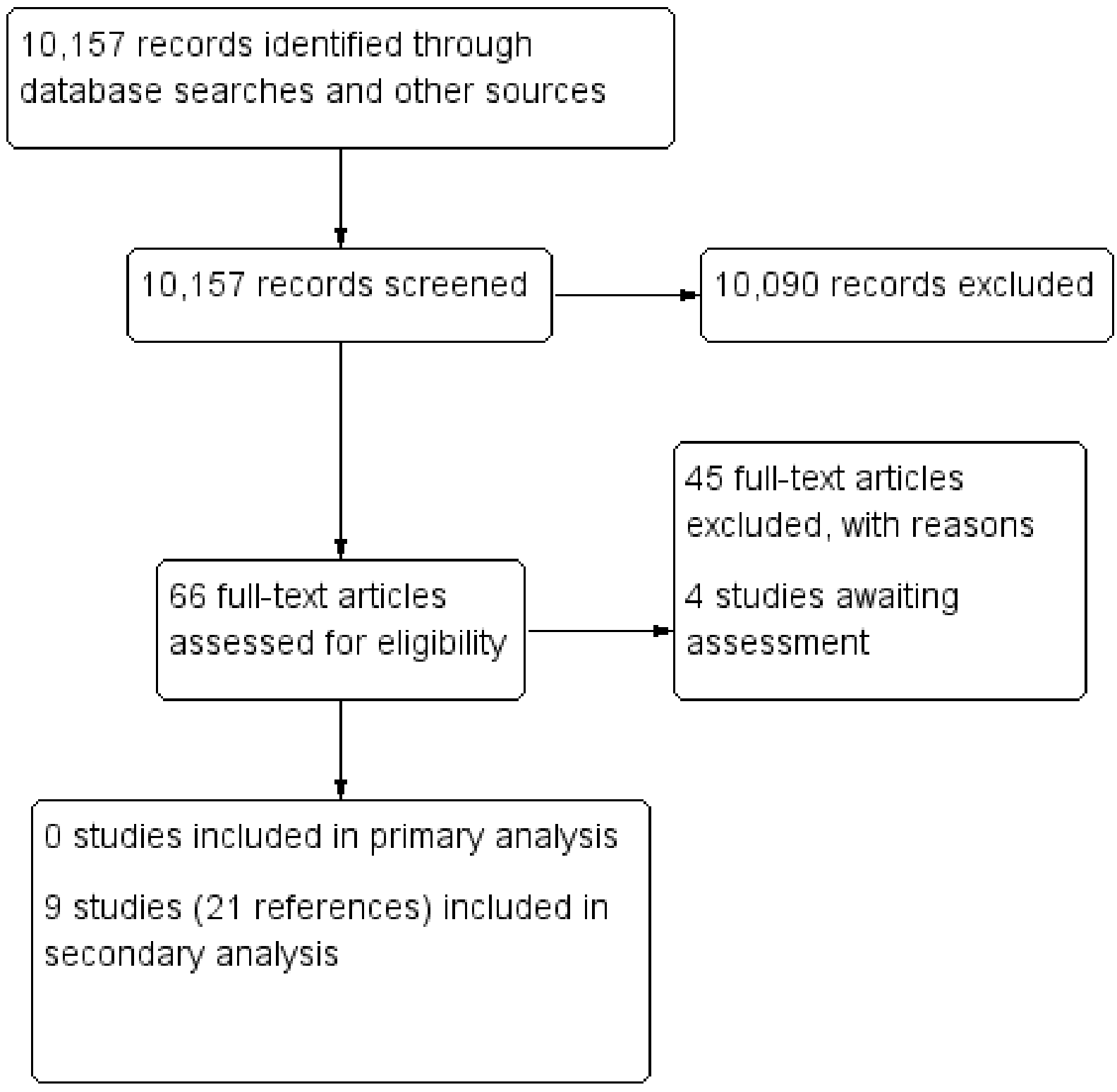




\section{Included studies}

Five included studies were conducted in the USA (USA 19932001; USA 1994-1998; USA 2002-2006; USA 2005-2014; USA 2006). The other four were from Germany, India, Kyrgyzstan and South Korea (Germany 2008; India 2001-2005; Kyrgyzstan 2001-2010; South Korea 2007).

The included studies considered the following types of interventions: dissemination of information (Germany 2008); improved detection and enforcement (South Korea 2007; USA 1994-1998); establishment of an independent agency and improved detection and enforcement (India 2001-2005; USA 1993-2001; USA 20052014); and increased transparency and accountability (Kyrgyzstan 2001-2010; USA 2002-2006; USA 2006).

The studies reported outcomes that included: physicians' attitudes (Germany 2008); number of complaints received and convictions (India 2001-2005); informal payments (Kyrgyzstan 2001-2010); overbilling (false or fraudulent claims) (South Korea 2007; USA 1993-2001); hospital utilisation, health outcomes and healthcare expenditures (USA 1994-1998); pharmaceutical company spending on gifts (USA 2002-2006); reports of fraud (USA 2006); money recovered from false or fraudulent claims, return on investment, new cases investigated, convictions, individuals and entities excluded from billing, and estimated programme savings (USA 2005-2014).

\section{Excluded studies}

We excluded 10 articles after full-text assessment because they did not meet our criteria for study design, nine because corruption was not an outcome, eight because the intervention was targeted at absenteeism, seven articles because the study did not describe an intervention, six because the focus was not on health care, three articles because they did not report a primary study, and two because they were methodology papers (see the 'Characteristics of excluded studies' table).

\section{Risk of bias in included studies}

One study had a comparison group (Germany 2008), two studies had before-and-after data (Kyrgyzstan 2001-2010; USA 1993-2001), one study compared varying expenditures on enforcement (as a measure of enforcement efforts) in a regression analysis (USA 1994-1998), one cross-sectional study examined the association between awareness of onsite investigations and overbilling (South Korea 2007), and another cross-sectional study examined associations between various internal control practices and reported fraud (USA 2006). The other three studies lacked both a comparison group and data from before the intervention (India 2001-2005; USA 2002-2006; USA 2005-2014).
One study, USA 2005-2014, provided high certainty evidence for the effect of a coordinated package of interventions on three outcomes. However, the extent to which those outcomes could be attributed to any specific intervention was uncertain. All other included studies provided low or very low certainty evidence.

\section{Effects of interventions}

See: Summary of findings for the main comparison Overview of evidence of the effects of interventions to reduce corruption; Summary of findings 2 Dissemination of information; Summary of findings 3 Improvement of detection and enforcement to reduce corruption; Summary of findings 4 Establishment of an independent agency with improvement of detection and enforcement; Summary of findings 5 Increased transparency and accountability

We have summarised the main findings of the nine included studies in Table 4. We grouped the interventions into four categories and prepared a 'Summary of findings table' for each category: dissemination of information (Summary of findings 2); improved detection and enforcement (Summary of findings 3); establishment of an independent agency with improved detection and enforcement (Summary of findings 4); and increased transparency and accountability (Summary of findings 5). We also prepared an overview of the evidence for all four categories (Summary of findings for the main comparison). We summarised our detailed judgements regarding the certainty of the evidence for the reported effects in Appendix 2, where we indicate the reasons for downgrading the certainty of the evidence. We have also included this information in footnotes in Table 4.

\section{Dissemination of information}

Gundermann and colleagues compared doctors' attitudes towards the pharmaceutical industry in one hospital with explicit guidelines that prohibited hospital doctors from accepting any form of benefits from the pharmaceutical industry compared to one hospital without guidelines (Germany 2008). The study found that $41 \%$ of doctors in the hospital with guidelines responded that it is acceptable to receive gifts from the pharmaceutical industry compared to $81 \%$ in the comparison hospital (RR 0.65, 95\% CI 0.48 to 0.91 ); and $9 \%$ of doctors in the hospital with guidelines responded that the pharmaceutical industry influences their prescribing compared to $31 \%$ in the comparison hospital (RR 3.6; 95\% CI 1.36 to 9.52). This low certainty evidence suggests that guidelines that prohibit hospital doctors from accepting any form of benefits from the pharmaceutical industry may change doctor's attitudes and their perceptions of the influence of the pharmaceutical industry on their prescribing behaviours (Summary of

Interventions to reduce corruption in the health sector (Review) 
findings 2). This study did not report adverse effects, resource use, impacts on healthcare or health outcomes.

One other study explicitly included dissemination of information as part of a coordinated package of interventions (USA 20052014). We have reported the results of this study below under the 'Establishment of an independent agency with improved detection and enforcement' section.

\section{Improved detection and enforcement}

Two studies evaluated improvements in the detection and punishment of corruption (South Korea 2007; USA 1994-1998).

Kang and colleagues examined associations between onsite investigation for false and fraudulent claims with penalties for wrong doers and a Costliness Index (CI), which is the ratio of observed to expected costs after controlling for case-mix (South Korea 2007). The study measured perceived deterrence regarding false and fraudulent claims via face-to-face interviews with the chief doctor of each clinic. They found a correlation between perceived deterrence (high versus low) and the CI of $-0.03(\mathrm{P}=0.03)$, and a correlation between knowledge about onsite investigations (high versus low) of $-0.03(\mathrm{P}<0.01)$. This suggests that clinics with perceived deterrence or fear of penalty attributable to a potential onsite investigation that is high might have a lower probability of presenting excessive claims than clinics that have low perceived deterrence, but the certainty of this evidence is very low (Summary of findings 3).

Becker and colleagues used variation in state-level Medicaid enforcement to identify the responsiveness of Medicare abuse to enforcement (USA 1994-1998). They used state Medicaid Fraud Control Units' expenditures as a proxy for overall anti-fraud enforcement efforts, because of extensive administrative overlap between the agencies responsible for policing Medicaid and Medicare. In regression analyses, they used state expenditures on enforcement as a measure of enforcement efforts, and examined correlations with utilisation, health outcomes and healthcare expenditures. They found that increased enforcement expenditures were associated with decreased expenditures on younger (age $<80$ years) Medicare patients. Increased enforcement expenditures were associated with greater declines in acute expenditures for patients who were initially admitted to a for-profit hospital compared to patients initially admitted to a non-profit hospital, and for patients admitted to a non-profit hospital compared to a public hospital. The effects of increased enforcement expenditures on hospital utilisation and health outcomes were inconclusive. For example, a $1 \%$ increase in expenditures was associated with a $0.4 \%$ increase in acute care hospital expenditures with a wide confidence interval. This evidence suggests that greater enforcement might lead to a reduction in healthcare expenditures in patient populations for whom additional treatment would be of marginal benefit, and the effects might be larger in for-profit hospitals than in non-profit hospitals, and larger in non-profit hospitals than in public hospi- tals, but the certainty of this evidence is very low (Summary of findings 3). The effects of increased enforcement expenditures on hospital utilisation and health outcomes are uncertain. Neither of these studies reported adverse effects.

Three other studies evaluated improved detection and enforcement as part of the mandate of an independent agency (India 2001-2005; USA 1993-2001; USA 2005-2014), and one study evaluated improved detection and enforcement together with increased transparency and accountability and decreased discretion (USA 2006). We have reported the results of these studies below.

\section{Establishment of an independent agency with improved detection and enforcement}

Three studies evaluated establishment of an independent agency with improved detection and punishment of corruption (India 2001-2005; USA 1993-2001; USA 2005-2014).

Huss and colleagues reported on the appointment of a well-known, retired judge to head an ombudsman's (Lokayukta) office and his newly appointed 'Vigilance Director for Health, Education and Family Welfare', a newly-created post in the state of Karnataka in India (India 2001-2005). The ombudsman and the Vigilance Director made the offices more accessible, visited every district and sub-district in the state where they investigated between 100 and 200 complaints every visit, extensively used the media, and attempted legal and administrative changes at the state and the national level. The paper reported annual data from a document review for four years after the appointments. The study did not present data from before the appointments. The number of complaints received increased from 1958 in the first year to between 7096 and 7732 in the following three years. The number of convictions increased from between 10 and 19 in the first 3 years to 41 in the last year. There was only one conviction in the health sector in the first year and one in the last year. This evidence suggests that an independent agency with strong leadership and political support, which is responsible for detecting corruption and enforcement, might increase the number of complaints received, but might have little or no impact on the number of convictions in the health sector (Summary of findings 4). However, the certainty of this evidence is very low. The lack of convictions might be due to a complex judicial system with its own integrity issues.

Enforcement of the US Health Insurance Portability and Accountability Act of 1996 (HIPAA), which went into effect 1 January 1997, gave the Office of the Inspector General coordination of federal, state and local enforcement efforts against healthcare fraud, including improper coding and billing of Medicare payments and the power to investigate and prosecute offenders. It also raised penalties for healthcare fraud. Harrington and colleagues examined changes in overbilling from before to after the HIPAA went into effect (USA 1993-2001). They controlled for the following hospital characteristics: the proportion of Medicare patients, size, income and teaching versus non-teaching. The study used up-cod- 
ing (the percent of a hospital's total charges that are coded as any of 17 "at-risk" diagnosis-related groups (DRGs)) as a measure of overbilling for services. Examples are upgrading transient ischaemic attacks to specific cerebrovascular disorders, simple pneumonia to respiratory infections with complications or pulmonary oedema and respiratory failure, and circulatory disorders without cardiovascular complication to circulatory disorder with complications. They found that up-coding increased steadily from 1993 to 1997 (by 13\%), levelled off in 1997 and then declined steadily until 2000 and was only slightly lower in 2001. Up-coding changed from $13.12 \%$ before to $12.10 \%$ after enforcement of the HIPAA (mean decrease 1.02\% (SD 3.03\%); median decrease 0.66\%). The greater the level of up-coding was in a hospital prior to HIPAA, the greater the up-coding was reduced after the HIPAA. This evidence suggests that establishment of an independent agency to investigate and enforce efforts against overbilling might lead to a small reduction in up-coding, but the certainty of this evidence is very low (Summary of findings 4). The lack of decline in upcoding in 1997 and the steady decline from 1998 to 2001 suggests that the Office of the Inspector General's enforcement actions were necessary to implement the HIPAA.

The US Department of Health and Human Services (DHHS) and Department of Justice (DOJ) report annually to the US Congress on the Health Care Fraud and Abuse Control Program (USA 2005-2014). Anti-fraud efforts by the DHHS, the DoJ and other agencies were consolidated and strengthened by the HIPAA in 1996. Subsequent legislation and executive action included the Senior Medicare Patrol (Older Americans Act) in 1997, the Healthcare Fraud Prevention and Enforcement Action Team (HEAT) in 2009, the Affordable Care Act in 2010, and the Public-Private Partnership to Prevent Health Care Fraud in 2012. Activities undertaken by the DHHS, DoJ and other agencies include: obtaining more sophisticated computer analytic capacity to review payment trends and spot improper billing, stricter healthcare fraud and abuse control laws, prepayment claim checking, manual reviews, educating providers, provider enrolment screening and restructuring programmes. There were between 836 and 1131 new healthcare fraud cases per year, and between 523 and 826 convictions per year from 2005 to 2014 (Table 5). Between 2662 and 4017 individuals and entities were excluded from participation in Medicare, Medicaid and other federal healthcare programmes per year. The Federal government has collected between USD 1 and 3 billion annually from fraud judgements and settlements. This represents a return of between USD 6.8 and USD 8.1 per USD 1 spent. The estimated Medicare savings were from USD 5.5 to 29.8 billion per year, and the estimated Medicaid savings were from USD 0.5 to 12.3 billion per year.

The package of interventions coordinated by the DHHS and the DoJ recovered a large amount of money and resulted in hundreds of new cases and convictions each year, and the amount recovered by the Federal government exceeds the amount spent on enforcement efforts (high certainty of the evidence) (Summary of findings
4). The package of interventions coordinated by the DHHS and the DoJ may result in substantial savings to the Medicare and Medicaid programmes (low certainty of the evidence). The estimated amount recovered and saved is between 15\% and 55\% of the estimated total amount of fraudulent billings in the USA for 2014 (CMS 2015; FBI 2011).

None of these studies reported adverse effects, healthcare or health outcomes.

\section{Increased transparency and accountability}

Three studies evaluated interventions to increase transparency and accountability (Kyrgyzstan 2001-2010; USA 2002-2006; USA 2006).

Aleshkina and colleagues examined the impacts of a reform in Kyrgyzstan using before-and-after data from national surveys (Kyrgyzstan 2001-2010). By increasing the transparency of the copayment system and by improving the flow of resources to healthcare providers, it was hoped that health financing reforms would reduce or eliminate informal payments, particularly in hospitals. By changing the structure of funding (to case-based payment for inpatient care and capitation payment for primary care in 1997) and by introducing a split between the purchasers and providers, as well as better payment to the providers, it was also hoped that there would be less incentive to demand informal payments. The new financial arrangements included pooling of all local budget funds for health, payment of providers from these funds, de-linking the amount of budget revenues received by a facility from the number of beds that it had, and establishment of an explicit, formal and differentiated co-payment for inpatient care (20012004). The proportion of people who reported they made other payments in connection with a consultation decreased from 55\% in 1994 to $20 \%$ in 2007 . There should have been no other charges after 2004 when the reform was expanded from two provinces to the whole country. The proportion of people who reported making any payment at a family general practitioner decreased from $17 \%$ in 2004 to $13 \%$ in 2007 , and the proportion of patients that paid at a polyclinic/family medical centre decreased from $45 \%$ in 2004 to $23 \%$ in 2007 (and no one in 2007 reported making a payment for maternity care). This low certainty evidence suggests that a reform that increases transparency and accountability for co-payments and reduces incentives for demanding informal payments may reduce informal payments.

Chimonas and colleagues, USA 2002-2006, evaluated legislation in Vermont, a state in the USA, that required pharmaceutical companies to report "the value, nature, and purpose" of gifts to healthcare providers in excess of USD 25. Companies that failed to file disclosures faced USD 10,000 fines and legal action by the state's Attorney General. The Attorney General's office posted annual reports on the aggregate data on its website. Postintervention trends using company disclosure data collected by the Attorney General's office showed that over four years, total pharmaceutical 
company spending on gifts was not reduced, and some items increased; e.g. speakers' fees quadrupled and gifts of food increased by $51 \%$. Companies increasingly used loopholes in the law (a trade secret provision) to avoid public scrutiny. The proportion of companies using this provision nearly doubled, from $24 \%$ to $42 \%$. The percentage of payments categorised as trade secret increased by one third, from $54 \%$ to $72 \%$. This evidence suggests that restrictions on pharmaceutical company gifts, disclosure and penalties for non-disclosure might not reduce spending on gifts, but the certainty of this evidence is very low.

In a cross-sectional study, Dietz and Snyder examined associations between a variety of internal control practices in community health centres (CHCs) in the USA and fraud (reported by the CHCs) (USA 2006). Frequencies were measured on a scale from 1 to 7 . The following internal control practices that increase transparency and accountability or that reduce discretion were reported to be used more frequently in $\mathrm{CHCs}$ that did not report fraud: board training in financial management (2.49 mean difference; $\mathrm{P}<0.001)$, vacation policies enforced (2.819; $\mathrm{P}<0.001)$, use of stamps for signatures $(0.515 ; \mathrm{P}<0.048)$, bonding employees (purchasing an insurance policy to protect the $\mathrm{CHC}$ against losses caused by fraud or dishonesty by employees) (3.102; $\mathrm{P}<0.001)$, physical security reviews $(1.599 ; \mathrm{P}<0.001)$, issuing receipts for fees $(0.840 ; \mathrm{P}=0.032)$, review of specification for insurance quotes (0.881; $\mathrm{P}=0.030)$, entry of financial data $(0.476 ; \mathrm{P}<0.009)$, and receiving and checking purchases $(0.487 ; \mathrm{P}<0.048)$. This evidence suggests that the following internal control practices might reduce fraud: board training in financial management, enforcement of vacation policies, using stamps for signatures, bonding employees, physical security reviews, issuing receipts for fees, reviewing specification for insurance quotes, entering financial data into records, and receiving and checking purchases. However, the certainty of the evidence of the effects of these and other practices examined in this study is very low. 


\section{ADDITIONALSUMMARY OF F INDINGS [Explanation]}

\begin{tabular}{|c|c|c|c|}
\hline \multicolumn{4}{|c|}{$\begin{array}{l}\text { Patients or population: doctors } \\
\text { Settings: two hospitals in Germany } \\
\text { Intervention: guidelines that prohibited doctors from accepting benefits from the pharmaceutical industry } \\
\text { Comparison: no guidelines }\end{array}$} \\
\hline Outcomes & Impacts & Studies & $\begin{array}{l}\text { Certainty of the evidence } \\
\text { (GRADE) }\end{array}$ \\
\hline $\begin{array}{l}\text { Corruption } \\
\text { Attitudies }\end{array}$ & $\begin{array}{l}\text { Guidelines that prohibit hos- } \\
\text { pital doctors from accepting } \\
\text { any form of benefits from the } \\
\text { pharmaceutical industry may } \\
\text { change doctor's attitudes and } \\
\text { their perceptions of the influ- } \\
\text { ence of the pharmaceutical in- } \\
\text { dustry on their prescribing be- } \\
\text { haviours }\end{array}$ & Germany 2008 & $\begin{array}{l}\oplus \oplus \ominus \ominus \\
\text { LoW }\end{array}$ \\
\hline Adverse effects & Not reported & - & - \\
\hline Resource use & Not reported & - & - \\
\hline $\begin{array}{l}\text { Healthcare and health out- } \\
\text { comes }\end{array}$ & Not reported & - & - \\
\hline
\end{tabular}

* GRADE Working Group grades of evidence

High: this research provides a very good indication of the likely effect. The likelihood that the effect will be substantially different ${ }^{\dagger}$ is low.

Moderate: this research provides a good indication of the likely effect. The likelihood that the effect will be substantially different $^{\dagger}$ is moderate.

Low: this research provides some indication of the likely effect. However, the likelihood that it will be substantially different $\dagger$ is high.

Very low: this research does not provide a reliable indication of the likely effect. The likelihood that the effect will be substantially different ${ }^{\dagger}$ is very high.

† Substantially different: a large enough difference that it might affect a decision

Improvement of detection and enforcement to reduce corruption

Participants or population: health professionals

Settings: a) clinics in South Korea, and b) hospitals in the USA

Intervention: a) onsite investigation for false and fraudulent claims and penalty for wrong doers, b) increased expenditure on fraud enforcement efforts

Comparison: a) no onsite investigation for false and fraudulent claims, b) less expenditure on fraud enforcement efforts

$\begin{array}{lll}\text { Outcomes } & \text { Impacts } & \text { Studies }\end{array}$

Interventions to reduce corruption in the health sector (Review)

Copyright (C) 2016 The Authors. Cochrane Database of Systematic Reviews published by John Wiley \& Sons, Ltd. on behalf of The

Cochrane Collaboration. 


\begin{tabular}{|c|c|c|c|}
\hline $\begin{array}{l}\text { Corruption } \\
\text { Overbilling (false or fraudu- } \\
\text { lent claims) }\end{array}$ & $\begin{array}{l}\text { Clinics whose perceived de- } \\
\text { terrence or fear of penalty at- } \\
\text { tributable to a potential onsite } \\
\text { investigation is high might } \\
\text { have a lower probability of } \\
\text { presenting excessive claims } \\
\text { than those whose perceived } \\
\text { deterrence is low, but the cer- } \\
\text { tainty of this evidence is very } \\
\text { low }\end{array}$ & South Korea 2007 & $\begin{array}{l}\bigoplus \ominus \ominus \ominus \\
\text { Very low }\end{array}$ \\
\hline Adverse effects & Not reported & - & - \\
\hline $\begin{array}{l}\text { Resource use } \\
\text { Healthcare expenditures }\end{array}$ & $\begin{array}{l}\text { Greater enforcement might } \\
\text { lead to a reduction in health- } \\
\text { care expenditures in patient } \\
\text { populations for whom addi- } \\
\text { tional treatment would be of } \\
\text { marginal benefit, and the ef- } \\
\text { fects might be larger in for- } \\
\text { profit hospitals than in non- } \\
\text { profit hospitals, and larger in } \\
\text { non-profit hospitals than in } \\
\text { public hospitals, but the cer- } \\
\text { tainty of this evidence is very } \\
\text { low }\end{array}$ & USA 1994-1998 & $\begin{array}{l}\oplus \ominus \ominus \ominus \\
\text { Very low }\end{array}$ \\
\hline $\begin{array}{l}\text { Healthcare and health out- } \\
\text { comes } \\
\text { Utilisation and health out- } \\
\text { comes }\end{array}$ & $\begin{array}{l}\text { The effects of increased en- } \\
\text { forcement expenditures on } \\
\text { hospital utilisation and health } \\
\text { outcomes are uncertain }\end{array}$ & USA 1994-1998 & $\begin{array}{l}\oplus \ominus \ominus \ominus \\
\text { Very low }\end{array}$ \\
\hline
\end{tabular}

* GRADE Working Group grades of evidence

High: this research provides a very good indication of the likely effect. The likelihood that the effect will be substantially different ${ }^{\dagger}$ is low.

Moderate: this research provides a good indication of the likely effect. The likelihood that the effect will be substantially different $^{\dagger}$ is moderate.

Low: this research provides some indication of the likely effect. However, the likelihood that it will be substantially different $\dagger$ is high.

Very low: this research does not provide a reliable indication of the likely effect. The likelihood that the effect will be substantially different ${ }^{\dagger}$ is very high.

†Substantially different $=$ a large enough difference that it might affect a decision

Establishment of an independent agency and improvement of detection and enforcement to reduce corruption

Interventions to reduce corruption in the health sector (Review) 
Participants or population: a) hospitals, b) hospitalised Medicare patients, c) Medicaid and Medicare patients Settings: a) India, b) USA, c) USA

Intervention: a) appointment of ombudsman and vigilance director, b) coordination of federal, state and local enforcement efforts against healthcare fraud, c) a coordinated package of interventions ${ }^{1}$

Comparison: a) none ${ }^{2}$ b) less expenditures on enforcement efforts, c) none ${ }^{2}$

\begin{tabular}{|c|c|c|c|}
\hline Outcomes & Impacts & Studies & Certainty of the evidence (GRADE) \\
\hline $\begin{array}{l}\text { Corruption } \\
\text { Complaints and convictions }\end{array}$ & $\begin{array}{l}\text { An independent agency with } \\
\text { strong leadership and politi- } \\
\text { cal support, which is respon- } \\
\text { sible for detecting corruption } \\
\text { and enforcement might in- } \\
\text { crease the number of com- } \\
\text { plaints received, but might } \\
\text { have little or no impact on the } \\
\text { number of convictions in the } \\
\text { health sector (possibly due } \\
\text { to a complex judicial system } \\
\text { with its own integrity issues). } \\
\text { However, the certainty of this } \\
\text { evidence is very low }\end{array}$ & India 2001-2005 & $\begin{array}{l}\bigoplus \ominus \ominus \ominus \\
\text { Very low }\end{array}$ \\
\hline $\begin{array}{l}\text { Corruption } \\
\text { Overbilling }\end{array}$ & $\begin{array}{l}\text { Establishment of an indepen- } \\
\text { dent agency to investigate } \\
\text { and enforce efforts against } \\
\text { overbilling might lead to a } \\
\text { small reduction in up-coding, } \\
\text { but the certainty of this evi- } \\
\text { dence is very low }\end{array}$ & USA 1993-2001 & $\begin{array}{l}\oplus \ominus \ominus \ominus \\
\text { Very low }\end{array}$ \\
\hline $\begin{array}{l}\text { Corruption } \\
\text { Enforcement actions }\end{array}$ & $\begin{array}{l}\text { A coordinated package of in- } \\
\text { terventions }{ }^{1} \text { results in many } \\
\text { new healthcare fraud cases } \\
\text { and convictions each year }\end{array}$ & USA 2005-2014 & $\begin{array}{l}\oplus \oplus \oplus \oplus \\
\text { High }\end{array}$ \\
\hline Adverse effects & Not reported & - & - \\
\hline $\begin{array}{l}\text { Resource use } \\
\text { Amount collected and return } \\
\text { on investment }\end{array}$ & $\begin{array}{l}\text { A coordinated package of } \\
\text { interventions }{ }^{1} \text { recovers a } \\
\text { large amount of money The } \\
\text { amount recovered exceeds } \\
\text { the amount spent on enforce- } \\
\text { ment efforts }\end{array}$ & USA 2005-2014 & $\begin{array}{l}\oplus \oplus \oplus \oplus \\
\text { High }\end{array}$ \\
\hline $\begin{array}{l}\text { Resource use } \\
\text { Estimated programme sav- } \\
\text { ings }\end{array}$ & $\begin{array}{l}\text { A coordinated package of in- } \\
\text { terventions }{ }^{1} \text { may result in sub- } \\
\text { stantial savings to the govern- } \\
\text { ment (payer) }\end{array}$ & USA 2005-2014 & $\begin{array}{l}\oplus \oplus \ominus \ominus \\
\text { Low }\end{array}$ \\
\hline
\end{tabular}

Interventions to reduce corruption in the health sector (Review) 
Healthcare and health out- Not reported comes

* GRADE Working Group grades of evidence

High: this research provides a very good indication of the likely effect (because of a very strong association). The likelihood that the effect will be substantially different ${ }^{\dagger}$ is low.

Moderate: this research provides a good indication of the likely effect. The likelihood that the effect will be substantially different $^{\dagger}$ is moderate.

Low: this research provides some indication of the likely effect. However, the likelihood that it will be substantially different ${ }^{\dagger}$ is high.

Very low: this research does not provide a reliable indication of the likely effect. The likelihood that the effect will be substantially different ${ }^{\dagger}$ is very high.

$\dagger$ Substantially different: a large enough difference that it might affect a decision

${ }^{1}$ Activities undertaken by the Department of Health and Human Services, the Department of Justice, and other agencies included: obtaining more sophisticated computer analytic capacity to review payment trends and spot improper billing, stricter healthcare fraud and abuse control laws, prepayment claim checking, manual reviews, educating providers, provider enrolment screening, and restructuring programmes.

${ }^{2}$ Post-intervention data only.

Increased transparency and accountability to reduce corruption

Participants or population: a) pharmaceutical companies, b) community health centre staff, c) health service users Settings: a) USA, b) USA, c) Kyrgyzstan

Intervention: a) restrictions on pharmaceutical company gifts, b) internal control practices, c) increased transparency and accountability for co-payments and reduced incentives for informal payments

Comparison: a) none ${ }^{1}$, b) absence of specific control practices, c) status quo prior to reform

\begin{tabular}{|c|c|c|c|c|}
\hline Outcomes & & Impacts & Studies & Certainty of the evidence (GRADE)* \\
\hline $\begin{array}{l}\text { Corruption } \\
\text { Pharmaceutical } \\
\text { spending on gifts }\end{array}$ & company & $\begin{array}{l}\text { Restrictions on pharmaceuti- } \\
\text { cal company gifts, disclosure, } \\
\text { and penalties for non-disclo- } \\
\text { sure might not reduce spend- } \\
\text { ing on gifts, but the certainty } \\
\text { of this evidence is very low }\end{array}$ & USA 2002-2006 & $\begin{array}{l}\oplus \ominus \ominus \ominus \\
\text { Very low }\end{array}$ \\
\hline $\begin{array}{l}\text { Corruption } \\
\text { Fraud }\end{array}$ & & $\begin{array}{l}\text { The effects of internal control } \\
\text { practices on reducing fraud } \\
\text { in community health centres } \\
\text { is uncertain. The following } \\
\text { might reduce fraud: board } \\
\text { training in financial manage- } \\
\text { ment, enforcement of vaca- } \\
\text { tion policies, using stamps } \\
\text { for signatures, bonding em- } \\
\text { ployees, physical security re- }\end{array}$ & USA 2006 & $\begin{array}{l}\oplus \ominus \ominus \ominus \\
\text { Very low }\end{array}$ \\
\hline
\end{tabular}

Interventions to reduce corruption in the health sector (Review)

Copyright ( 2016 The Authors. Cochrane Database of Systematic Reviews published by John Wiley \& Sons, Ltd. on behalf of The

Cochrane Collaboration. 


\begin{tabular}{lll} 
& $\begin{array}{l}\text { views, issuing receipts for } \\
\text { fees, reviewing specification } \\
\text { for insurance quotes, enter- } \\
\text { ing financial data into records, } \\
\text { and receiving and checking } \\
\text { purchases. However, the cer- } \\
\text { tainty of this evidence is very } \\
\text { low }\end{array}$ & A \\
\hline $\begin{array}{l}\text { Corruption } \\
\text { Informal payments }\end{array}$ & $\begin{array}{l}\text { parency and accountability } \\
\text { for co-payments and reduces } \\
\text { incentives for demanding in- } \\
\text { formal payments may reduce } \\
\text { informal payments }\end{array}$ & Low \\
\hline Adverse effects & Not reported & - \\
\hline Resource use & Not reported & - \\
\hline comealthcare and health out- & Not reported & - \\
\hline
\end{tabular}

* GRADE Working Group grades of evidence

High: this research provides a very good indication of the likely effect. The likelihood that the effect will be substantially different ${ }^{\dagger}$ is low.

Moderate: this research provides a good indication of the likely effect. The likelihood that the effect will be substantially different $^{\dagger}$ is moderate.

Low: this research provides some indication of the likely effect. However, the likelihood that it will be substantially different $\dagger$ is high.

Very low: this research does not provide a reliable indication of the likely effect. The likelihood that the effect will be substantially different ${ }^{\dagger}$ is very high.

†ubstantially different: a large enough difference that it might affect a decision

${ }^{1}$ Postintervention data only.

\section{DISCUSSION}

\section{Summary of main results}

Although we did not find any studies that met the criteria for our primary analysis, one of the included case studies, USA 2005-2014, provided high certainty evidence that a package of interventions coordinated by the US Department of Health and $\mathrm{Hu}-$ man Services and Department of Justice recovers a large amount of money and results in hundreds of new cases and convictions each year (Summary of findings 4). The amount recovered by the Federal government through this package of interventions is seven or eight times the amount spent on enforcement efforts. The interventions include obtaining more sophisticated computer analytic capacity to review payment trends and spot improper billing, stricter healthcare fraud and abuse control laws, prepayment claim checking, manual reviews, educating providers, provider enrolment screening and restructuring programmes. The extent to which each of these components contributed to the impacts of the legislation and its implementation is uncertain. The extent to which the evidence is transferable to other healthcare systems is 
also uncertain. The included case study from India suggests that the impacts of coordinated efforts to reduce corruption through increased detection and enforcement are dependent on continued political support and that they can be limited by a dysfunctional judicial system (India 2001-2005).

Other promising interventions for which there is low certainty evidence that they may reduce corruption include guidelines that prohibit hospital doctors from accepting any form of benefits from the pharmaceutical industry (Summary of findings 2), and increasing transparency and accountability for co-payments together with reducing incentives for demanding informal payments (Summary of findings 5). The following interventions might reduce corruption, but the certainty of the evidence of their effects is very low: onsite investigation for false and fraudulent claims, increasing expenditure on fraud enforcement for claims alone (i.e. not as part of a package of interventions) (Summary of findings 3), and internal control practices in community health centres (CHCs) (Summary of findings 5).

\section{Overall completeness and applicability of evidence}

There is a paucity of evidence of the effects of interventions to reduce corruption (Summary of findings for the main comparison). None of the papers that we included examined potential adverse effects or impacts on equity, and there were no reliable data for impacts on healthcare or health. We did not find any studies that met our selection criteria for interventions that increased the range of choice of alternative suppliers or providers of services. Only one included study assessed interventions that decrease discretion (USA 2006), and only one included study assessed an intervention that reduced incentives for corruption (Kyrgyzstan 2001-2010). Five of the nine included studies were from the USA (USA 19932001; USA 1994-1998; USA 2002-2006; USA 2005-2014; USA 2006). Three of those focused on interventions where the primary aim was detection and punishment of fraudulent Medicaid and Medicare billing (USA 1993-2001; USA 1994-1998; USA 20052014). Although there is little question that coordinated efforts to detect and punish fraudulent billing in the USA lead to convictions and recovered funds, it is unlikely that similar efforts in countries with fewer resources and more dysfunctional legal systems would have similar impacts. Moreover, components of those efforts might not be feasible in some low-income settings, such as sophisticated computer analytic capacity to review payment trends and spot improper billing.

Four included studies assessed the impacts of interventions to detect and punish fraudulent billing (misinformation) (South Korea 2007; USA 1993-2001; USA 1994-1998; USA 2005-2014). Two included studies assessed the impacts of interventions targeted at illegal charges to patients (India 2001-2005; Kyrgyzstan 2001-2010). Two included studies assessed the impacts of interventions to reduce pharmaceutical company gifts to doctors (bribes) (Germany 2008; USA 2002-2006), and one other study assessed an intervention to reduce other bribes (as well as illegal charges to patients and absenteeism) (India 2001-2005). Only one study assessed interventions targeted at fraud in CHCs (theft or misinformation) (USA 2006). None of the included studies assessed the impacts of interventions targeted at embezzlement, private use of public facilities, or bribes to government regulators or payers (Table 2).

Possible reasons for the paucity of evidence on the effects of interventions to reduce corruption include a lack of funding for evaluations of interventions to reduce corruption, a tendency for research to focus on documenting the extent of corruption rather than on interventions to reduce corruption, and a failure to use rigorous methods when the effects of interventions to reduce corruption are evaluated (see the 'Excluded studies' section). On the other hand, the one evaluation that provided compelling evidence of the effects of an intervention to reduce corruption suggests that it is possible to document at least some of the effects of interventions to reduce corruption using routinely-collected data as part of anticorruption efforts (USA 2005-2014). Moreover, it is feasible to undertake rigorous evaluations of the effects of interventions to reduce corruption (Björkman 2007; Björkman 2009; Blais 2007; Ferraz 2005), and others have recognised the need for rigorous evaluations (Johnsøn 2013; Peisakhin 2011). However, it seems likely that this need is not widely recognised, given how few rigorous evaluations we found.

\section{Certainty of the evidence}

With one exception (USA 2005-2014), all of the included studies were at high risk of bias and the certainty of the evidence was either low or very low. Moreover, apart from the three studies that evaluated efforts to detect and punish fraudulent Medicaid and Medicare billing in the USA (USA 1993-2001; USA 1994-1998; USA 2005-2014), there was only one study for each of the other interventions, so that the applicability of the evidence to other settings is uncertain.

Although the US Department of Health and Human Services and Department of Justice annual reports only provided postintervention data without a comparison, we judged the evidence for new cases, convictions and recovery of funds to be high certainty, because of the magnitude of the effects which could not have occurred without efforts to detect and punish fraudulent billing.

\section{Potential biases in the review process}

We used a broad search strategy, which included efforts to find grey literature. Nonetheless, it is possible that we did not find all case studies that meet the inclusion criteria for our secondary analysis, especially studies that suggest little or no effect of the evaluated interventions. It is also possible that our selection criteria excluded 
reports that might describe strategies that were found not to be feasible or acceptable, and that some studies we excluded on the basis of title and abstract could have provided information about the feasibility and acceptability of interventions. Consequently, and based on the case studies that we included, it is difficult to draw conclusions about strategies that are unlikely to warrant further evaluation. It is also likely that we excluded descriptions of strategies that have been tried and described when we screened by titles and abstracts, so that we cannot draw conclusions about this beyond describing the strategies that are described in the case studies that we selected for inclusion in our secondary analysis. As we stated in our protocol, Gaitonde 2010, we do not intend to systematically review the same broad range of study designs in updates of this Cochrane review, thus this will eliminate any risk of bias in how we searched for and selected case studies.

\section{Agreements and disagreements with other studies or reviews}

Rashidian 2012 reviewed interventional studies with or without a concurrent control group that evaluated the effectiveness of interventions to combat healthcare fraud and abuse. They conducted their searches on healthcare databases from 1975 to 2008. Four studies met their inclusion criteria and they concluded that there is a lack of evidence of the effect of interventions to combat healthcare fraud. We included one of those studies (USA 1994-1998), and excluded the other three (Liou 2008; Rivers 2005; Yang 2006). We included eight other studies that they did not include, including one that provided high certainty evidence of the effects of the coordination of federal, state and local enforcement efforts against Medicaid and Medicare fraud in the USA (USA 2005-2014). Our main conclusion, that there is a paucity of evidence, nonetheless agrees with their conclusion.

Kiwanuka 2014 reviewed studies on the effects of interventions for managing absenteeism among health workers. They searched up to 2011 and found 16 studies that met their inclusion criteria (unpublished data). Two of these studies evaluated the effect of monetary incentives on absenteeism (Curran 1987; Stephens 1978), and one study evaluated the effect of feedback on absenteeism (Gaudine 2001). The rest evaluated the effects of health promotion and prevention interventions on absenteeism, such as influenza vaccination, exercise, stress management and workplace support. None directly assessed the effects of interventions to address fraud (spending less time than contracted to deliver care for illegitimate reasons). We did not include studies of the effects of interventions for managing absenteeism in this review, and it appears unlikely that any of the studies that met their inclusion criteria addressed corruption. Although monetary incentives might reduce absenteeism, it is not possible to determine the extent to which monetary incentives or feedback reduced corruption rather than legitimate absenteeism in the three studies that met the in- clusion criteria of Kiwanuka 2014, all of which reported effects on absenteeism, not illegitimate absenteeism.

The case study we included that assessed the effects of restrictions on and disclosure of pharmaceutical company gifts to physicians suggested that disclosure and penalties for non-disclosure might not reduce spending on gifts (USA 2002-2006). This is consistent with other experiences in the USA, including the release of the Open Payment Program (OPP) database by the Centers for Medicare \& Medicaid Services (Santhakumar 2015), and state and industry disclosure websites used to inform the development of a federal website, required by the Physician Payment Sunshine Act (Hwong 2014). The OPP database includes payments made to physicians and teaching hospitals by manufacturers of federallycovered drugs, devices, biologics or medical supplies. It also includes physician ownership or investment interest in manufacturers or in group purchasing organisations. The effects of releasing these data and other data remains uncertain (Santhakumar 2015); legislation that requires the disclosure of payments to physicians may not provide easy access to payment information for the public and the data may be of limited quality once accessed (Ross 2007). A systematic review of legislative, educational, policy and other interventions that targeted physicians' interactions with pharmaceutical companies included one randomised trial and three nonrandomised studies (Alkhaled 2014). It concluded that the available evidence suggests a potential impact of policies aimed at reduction of interactions between physicians and drug representatives on physicians' prescription behaviour. It found no evidence concerning interventions that affected other types of interaction with pharmaceutical companies. This is consistent with our finding based on one study (Germany 2008), which Alkhaled 2014 did not include. Gunderman and colleagues found that guidelines that prohibit hospital doctors from accepting any form of benefits from the pharmaceutical industry may change doctor's attitudes and their perceptions of the influence of the pharmaceutical industry on their prescribing behaviours (low certainty of the evidence) (Germany 2008).

A review of the literature on using data mining to detect healthcare fraud and abuse found that most of the identified literature focused on the technical methods used and paid little attention to the practical implications of their findings for healthcare managers and decision makers (Joudaki 2014). This is consistent with our findings.

A Campbell review of community monitoring to curb corruption (Molina 2013), and another Campbell review on the impacts of administrative and bureaucratic reforms in the public sector on corruption are in progress (Killias 2016). Hanna 2011 reviewed the effectiveness of micro-level anti-corruption strategies implemented in developing countries. Of the 14 studies that met their inclusion criteria, only one was in the health sector (Banerjee 2007), and that study did not meet our inclusion criteria. Lynch 2013 reviewed studies on the effects of community accountability mechanisms and processes in developing countries. They found

Interventions to reduce corruption in the health sector (Review) 
only two studies that focused explicitly on the prevention of corruption (Casey 2011; Reinikka 2011), neither of which met our inclusion criteria. We have not found any other systematic reviews of the effects of interventions to reduce corruption or of case studies of efforts to reduce corruption.

\section{AUTHORS, CONCLUSIONS}

\section{Implications for practice}

There is a large amount of corruption in the health sector and, consequently, wasted resources, worse health care and worse health outcomes. There is a paucity of evidence regarding how best to reduce corruption. Nonetheless, policymakers and other stakeholders who are concerned about corruption must make decisions about what to do. Promising interventions include improvements in the detection and punishment of corruption, especially efforts that are coordinated by an independent agency. Such efforts can have a large return on investment. However, it might not be possible to achieve similar effects in settings with a dysfunctional judicial system.

Other promising interventions include guidelines that prohibit doctors from accepting benefits from the pharmaceutical industry, internal control practices in community health centres (CHCs), and increased transparency and accountability for co-payments combined with reduced incentives for informal payments. The extent to which increased transparency alone reduces corruption is uncertain. Nonetheless, there are logical arguments for considering increased transparency, as well as other interventions for which we did not find any studies that met our inclusion criteria.

Given the size of the problem and the paucity of evidence of the effects of interventions to reduce corruption, there is a need to monitor the impacts of all interventions that are implemented, including potential adverse effects.

\section{Implications for research}

All interventions to reduce corruption are in need of evaluation. Randomised trials can be used to evaluate the effects of interventions to reduce corruption (Björkman 2007; Björkman 2009; Blais 2007; Ferraz 2005), and should be used whenever possible, to reduce the risk of bias in non-randomised evaluations (Johnsøn 2013; Peisakhin 2011). When randomised trials are not possible, ITS studies should be used when possible; and even when randomised trials are possible, controlled ITS analyses should be used when possible (Fretheim 2015). Potential adverse effects, impacts on equity and resource use should be evaluated, as well effects on corruption.

\section{ACKNOWLEDGEMENTS}

Arild Bjørndal and Pierre Ongolo-Zogo contributed to drafting and revising the protocol (Gaitonde 2010), article screening and data collection, but were not involved in the later stages or in the completion of this review. We are grateful for their contributions. We thank Marit Johansen, who developed and conducted most of the search strategies we used. We thank William D. Savedoff, Taryn Vian and Lucy Koechlin for helpful comments on the protocol for this review, and Taryn Vian and Maureen Lewis for their helpful comments on the full review.

The Norwegian Satellite of the Effective Practice and Organisation of Care (EPOC) Group receives funding from the Norwegian Agency for Development Cooperation (Norad), via the Norwegian Institute of Public Health to support review authors in the production of their reviews. This review is a product of the Effective Health Care Research Consortium, which provided funding to make this review open access. The Consortium is funded by UK aid from the UK Government for the benefit of developing countries (Grant: 5242). The views expressed in this review do not necessarily reflect UK government policy.

\section{R E F E R E N C E S}

\section{References to studies included in this review}

Germany 2008 \{published data only\}

Gundermann C, Meier-Hellmann A, Bauer M, Hartmann

M. [Effects of a mandatory guideline that prohibit hospital doctors from accepting any form of benefits in any form from the pharmaceutical industry] [Der Einfluss einer krankenhausinternen Richtlinieauf die Einstellung von Ärzten zur pharmazeutischenIndustrie]. Deutsche Medizinische Wochenschrift 2010;135(3):67-70.

India 2001-2005 \{published data only\}

Huss R, Green A, Sudarshan H, Karpagam SS, Ramani $\mathrm{KV}$, Tomson G, et al. Good governance and corruption in the health sector: lessons from the Karnataka experience. Health Policy and Planning 2010;26(6):471-84. [DOI: 10.1093/heapol/czq080]

Kyrgyzstan 2001-2010 \{published data only\} Aleshkina J, Akkazieva B, Jakab M. Access to healthcare services and out-of-pocket payments in Kyrgyzstan: Household survey from 2001 to 2010. Policy research paper

№ 76. Health Policy Analysis Center, Bishkek, Kyrgyzstan. WHO Barcelona Office for Health Systems Strengthening. WHO Regional Office for Europe. http://metakg.org/wpcontent/uploads/2014/04/4 Access-to-healthcare-services- 
and-out-of-pocket-payments.pdf (accessed 28 July 2016). Baschieri A, Falkingham J. Formalizing informal payments: the progress of health reform in Kyrgyzstan. 2006 Central Asian Survey;25(4):441-460.

Falkingham J, Akkazieva B, Baschieri A. Trends in out-ofpocket payments for health care in Kyrgyzstan, 2001-2007. Health Policy and Planning 2010;25(5):427-36.

Kutzin J, Ibraimova AS, Meimanaliev TS, Kadyrova $\mathrm{N}$, Schüth T. Addressing informal payments in Kyrgyz hospitals: a preliminary assessment. Eurohealth 2001;7(3): 90-6.

South Korea 2007 \{published data only\}

Kang H, Hong J, Lee K, Kim S. The effects of the fraud and abuse enforcement program under the National Health Insurance program in Korea. Health Policy 2010;95(1): 41-9.

USA 1993-2001 \{published data only\} Harrington K, Allen A, Ruchala L. Restraining Medicare abuse: the case of upcoding. Research in Healthcare Financial Management 2007;11(1):1-25.

USA 1994-1998 \{published data only\} Becker D, Kessler D, McClellan M. Detecting Medicare abuse. Journal of Health Economics 2005;24(1):189-210.

USA 2002-2006 \{published data only\}

Chimonas S, Rozario NM, Rothman DJ. Show us the money: lessons in transparency from state pharmaceutical marketing disclosure laws. Health Services Research 2010;45 (1):98-114.

USA 2005-2014 \{published data only\}

Department of Health and Human Services and Department of Justice. Health Care Fraud and Abuse Control Program Annual Report for Fiscal Year 2005. http: //oig.hhs.gov/reports-and-publications/hcfac/ (accessed 28 July 2016).

Department of Health and Human Services and Department of Justice. Health Care Fraud and Abuse Control Program Annual Report for Fiscal Year 2006. http: //oig.hhs.gov/reports-and-publications/hcfac/ (accessed 28 July 2016).

Department of Health and Human Services and Department of Justice. Health Care Fraud and Abuse Control Program Annual Report for Fiscal Year 2007. http: //oig.hhs.gov/reports-and-publications/hcfac/ (accessed 28 July 2016).

Department of Health and Human Services and Department of Justice. Health Care Fraud and Abuse Control Program Annual Report for Fiscal Year 2008. http: //oig.hhs.gov/reports-and-publications/hcfac/ (accessed 28 July 2016).

Department of Health and Human Services and Department of Justice. Health Care Fraud and Abuse Control Program Annual Report for Fiscal Year 2009. http: //oig.hhs.gov/reports-and-publications/hcfac/ (accessed 28 July 2016).

Department of Health and Human Services and Department of Justice. Health Care Fraud and Abuse Control Program Annual Report for Fiscal Year 2010. http: //oig.hhs.gov/reports-and-publications/hcfac/ (accessed 28 July 2016),

Department of Health and Human Services and Department of Justice. Health Care Fraud and Abuse Control Program Annual Report for Fiscal Year 2011. http: //oig.hhs.gov/reports-and-publications/hcfac/ (accessed 28 July 2016).

Department of Health and Human Services and Department of Justice. Health Care Fraud and Abuse Control Program Annual Report for Fiscal Year 2012. http: //oig.hhs.gov/reports-and-publications/hcfac/ (accessed 28 July 2016).

Department of Health and Human Services and Department of Justice. Health Care Fraud and Abuse Control Program Annual Report for Fiscal Year 2013. http: //oig.hhs.gov/reports-and-publications/hcfac/ (accessed 28 July 2016).

Department of Health and Human Services and Department of Justice. Health Care Fraud and Abuse Control Program Annual Report for Fiscal Year 2014. http: //oig.hhs.gov/reports-and-publications/hcfac/ (accessed 28 July 2016).

USA 2006 \{published data only\}

Dietz DK, Snyder H. Internal control differences between community health centers that did or did not experience fraud. January 1 2007. http://www.thefreelibrary.com/Internal+control+differences+between+community+health+centers+that...a0177055785 (accessed 28 July 2016).

\section{References to studies excluded from this review}

\section{3ie 2011 \{published data only\}}

Impact Initiative for Impact Evaluation (3ie). How to turn the tide on corruption? Number 17. June 2011. http://www.3ieimpact.org/media/filer public/2012/05/07/ Corruption brief.pdf (accessed 28 July 2016).

Aelvoet 2009 \{published data only\}

Aelvoet WH, Terryn N, Windey F, Redivo M, van Sprundel M, Faes C, Cell Audit. Miscoding: a threat to the hospital care system. How to detect it?. Revue d'Epidémiologie et de Santé Publique 2009;57(3):169-77.

\section{Alcázar 2001 \{published data only\}}

Alcázar L, Andrade R. Chapter 5: Induced demand an absenteeism in Peruvian Hospitals. In: Di Tella R, Savedoff WD editor(s). Diagnosis Corruption: Fraud in Latin America's Public Hospitals. Washington DC: Inter-American Development Bank, 2001.

Banerjee 2007 \{published data only\} Banerjee AV, Glennerster R, Duflo E. Putting a band-aid on a corpse: incentives for nurses in the Indian public health care system. Journal of the European Economic Association 2007;6(2-3):487-500.

Barber 2004 \{published data only\}

Barber S, Bonnet F, Bekedam H. Formalizing underthe-table payments to control out-of-pocket hospital 
expenditures in Cambodia. Health Policy and Planning 2004;19(4):199-208.

Barr 2009 \{published data only\}

Barr A, Lindelow M, Serneels P. Corruption in public service delivery: An experimental analysis. Journal of Economic Behavior \& Organization 2009;72(1):225-39.

Berge 2012 \{published data only\}

Berge KH, Dillon KR, Sikkink KM, Taylor TK, Lanier WL. Diversion of drugs within health care facilities, a multiplevictim crime: patterns of diversion, scope, consequences, detection, and prevention. Mayo Clinic Proceedings 2012;87 (7):674-82.

Björkman 2007 \{published data only\}

Björkman M, Svensson J. Power to the people: evidence from a randomized field experiment of a communitybased monitoring project in Uganda. http://cepr.org/ active/publications/discussion papers/dp.php?dpno $=6344$ (accessed 28 July 2016).

Björkman 2009 \{published data only\}

Björkman M, Svensson J. Power to the people: evidence from a randomized field experiment on community-based monitoring in Uganda. The Quarterly Journal of Economics 2009;124(2):735-69.

\section{Blais 2007 \{published data only\}}

Blais E, Bacher JL. Situational deterrence and claim padding: results from a randomized field experiment. Journal of Experimental Criminology 2007;3(4):337-52.

Brown 2015 \{published data only\}

Brown J, Mackay D, Demou E, Craig J, Frank J, Macdonald EB. The EASY (Early Access to Support for You) sickness absence service: a four-year evaluation of the impact on absenteeism. Scandinavian Journal of Work, Environment \& Health 2015;41(2):204-15.

Casey 2011 \{published data only\}

Casey K, Glennerster R, Miguel E. Reshaping institutions: evidence on aidimpacts using a pre-analysis plan. Working paper 17012. http://www.nber.org/papers/w17012.pdf. Cambridge, MA: Bureau of Economic Research, (accessed 28 July 2016).

Ching 2007 \{published data only\} Ching PL. Evaluating accountability in the Vaccines for Children program: protecting a federal investment. Public Health Reports 2007;122(6):718-24.

Cohen 2001 \{published data only\}

Cohen JC, Carikeo Montoya J. Using technology to fight corruption in pharmaceutical purchasing: lessons learned from the Chilean experience. February 20, 2001. http://citeseerx.ist.psu.edu/viewdoc/download;jsessionid= 83E7D5D39DDCF377F17FB6D8CAE58AD5?doi= 10.1.1.196.2132\&rep=rep1\&type=pdf. World Bank Institute, Washington, DC, (accessed 28 July 2016).

De Jaegere 2009 \{published data only\}

De Jaegere S, Finley S. Mapping accountability in the health sector and developing a sectoral assessment framework. UNDP mission report 2009.

\section{EHFCN 2013 \{published data only\}}

European Commission, Directorate-General Home Affairs. Study on corruption in the healthcare sector. HOME/2011/ ISEC/PR/047-A2 October 2013. http://ec.europa.eu/ dgs/home-affairs/what-is-new/news/news/docs/ 20131219 ' study' on ' corruption 'in ' the healthcare' sector' en.pdf (accessed 28 July 2016).

Ferraz 2005 \{published data only\}

Ferraz C, Finan F. Exposing corrupt politicians: the effects of Brazil's publicly released audits on electoral outcomes. IZA Discussion Papers, No. 2836. http://ftp.iza.org/ dp2836.pdf (accessed 28 July 2016).

Ferraz 2009 \{published data only\}

Ferraz C, Finan F. Electoral Accountability and Corruption: Evidence from the Audits of Local Governments. NBER Working Paper No. 14937. http://www.nber.org/papers/ w14937.pdf (accessed 28 July 2016).

García-Prado 2006 \{published data only\} García-Prado A, Chawla M. The impact of hospital management reforms on absenteeism in Costa Rica. Health Policy and Planning 2006;21(2):91-100.

Gatti 2002 \{published data only\}

Gatti R, Gray-Molina G, Klugman J. Determinants of corruption in local health care provision: Evidence from 108 municipalities in Bolivia. http://www.siepweb.it/siep/ oldDoc/wp/166.pdf. World Bank. Processed, (accessed 28 July 2016).

Gee 2011 \{published data only\}

Gee J, Button M, Brooks G. The financial cost of healthcare fraud. 2011 report. http://www.cfps.hscni.net/wp-content/ uploads/2012/11/PKF-Fraud FINAL.pdf. PKF (UK) LLP and University of Portsmouth, (accessed 28 July 2016).

Gellar 2008 \{published data only\}

Gellar S, Salam Fall A, Kimonyo JP, Friday B. Corruption assessment of Rwandan health sector. Washington, D.C.: United States Agency for International Development, 2008.

Giedion 2001 \{published data only\} Giedion U, Morales LG, Acosta OL. Chapter 6: The impact of health reforms on irregularities in Bogota hospitals. In: Di Tella R, Savedoff WD editor(s). Diagnosis Corruption: Fraud in Latin America's Public Hospitals. Washington DC: Inter-American Development Bank, 2001.

Gray-Molina 2001 \{published data only\} Gray-Molina G, Pérez de Rada E, Yañez E. Chapter 2: Does voice matter? Participation and controlling corruption in Bolivian hospitals. In: Di Tella R, Savedoff WD editor (s). Diagnosis Corruption: Fraud in Latin America's Public Hospitals. Washington DC: Inter-American Development Bank, 2001.

Greving 2007 \{published data only\} Greving JP, Denig P, de Zeeuw D, Haaijer-Ruskamp FM. Claims in advertisements for antihypertensive drugs in a Dutch medical journal. Journal of Hypertension 2007;25(3): $713-22$.

Interventions to reduce corruption in the health sector (Review) 
Jaén 2001 \{published data only\}

Jaén ME, Paravisini D. Chapter 3: Wages, capture and penalties in Venezuela's public hospitals. In: Di Tella R, Savedoff WD editor(s). Diagnosis Corruption: Fraud in Latin America's Public Hospitals. Washington DC: InterAmerican Development Bank, 2001.

Klitgaard 2006 \{published data only\}

Klitgaard R. Introduction: Subverting corruption. Global Crime 2006;7(3-4):299-307.

Lee 1990 \{published data only\}

Lee JB, Eriksen LR. The effects of a policy change on three types of absence. Journal of Nursing Administration 1990;20 $(7-8): 37-40$.

Leidalen 2011 \{published data only\}

Leidalen E, Skarpnord R, Omre SE. Monitoring provider fraud in Norway. Eurohealth 2011;17(4):25-26.

Liou 2008 \{published data only\}

Liou FM, Tang YC, Chen JY. Detecting hospital fraud and claim abuse through diabetic outpatient services. Health

Care Management Science 2008;11(4):353-8.

Luiselli 2008 \{published data only\}

Luiselli JK, DiGennaro Reed FD, Christian WP, Markowski A, Rue HC, St Amand C, et al. Effects of an informational brochure, lottery-based financial incentive, and public posting on absenteeism of direct-care human services employees. Behavior Modification 2009;33(2):175-81.

Markowich 1989 \{published data only\}

Markowich MM, Silver CA. How to reduce absenteeism: a comparative analysis. Hospital \& Health Services Administration 1989;34(2):213-29.

Olken 2007 \{published data only\}

Olken BA. Monitoring corruption: evidence from a field experiment in Indonesia. Journal of Political Economy 2007; 115(2):200-49.

Reinikka 2011 \{published data only\}

Reinikka R, Svensson J. Fighting corruption to improve schooling: evidencefrom a newspaper campaign in Uganda. Journal of the European Economic Association 2005;3(2-3): 259-67.

* Reinikka R, Svensson J. The power of information in public services: evidence from education in Uganda. Journal of Public Economics 2011;95(7-8):956-66.

Rivers 2005 \{published data only\}

Rivers PA, Dobalian A, Germinario FA. A review and analysis of the clinical laboratory improvement amendment of 1988: compliance plans and enforcement policy. Health Care Management Review 2005;30(2):93-102.

Schargrodsky 2001 \{published data only\}

Schargrodsky E, Mera J, Weinschelbaum F. Chapter 4: Transparency and accountability in Argentina's hospitals. In: Di Tella R, Savedoff WD editor(s). Diagnosis Corruption: Fraud in Latin America's Public Hospitals. Washington DC: Inter-American Development Bank, 2001.
Simoens 2009 \{published data only\}

Simoens S. Analysis of drug authentication at the point of dispensing in Belgian and Greek community pharmacies. Annals of Pharmacotherapy 2009;43(10):1701-6.

Soeters 2003 \{published data only\}

Soeters R, Griffiths F. Improving government health services through contract management: a case from Cambodia. Health Policy and Planning 2003;18(1):74-83.

Stephens 1978 \{published data only\} Stephens TA, Burroughs WA. An application of operant conditioning to absenteeism in a hospital setting. Journal of Applied Psychology 1978;63(4):518-21.

Stover 2001 \{published data only\}

Stover CC. Health financing and reform in Kenya: lessons from the field. A summary and assessment of the major accomplishments of the APHIA Financing and Sustainability (AFS) Project December 1996-June 2001. http://pdf.usaid.gov/pdf docs/Pnade338.pdf. Nairobi, Kenya, (accessed 28 July 2016).

UNDP 2011 \{published data only\} United Nations Development Programme. Fighting corruption in the health sector: methods, tools and good practices. 31 October 2011. http://www.undp.org/content/ undp/en/home/librarypage/democratic-governance/anticorruption/fighting corruptioninthehealthsector.html. United Nations Development Programme, (accessed dd Month yyyy).

\section{Vardi 1996 \{published data only\}}

Vardi A, Modan B, Blumstein Z, Lusky A, Schiff E, Barzilay $Z$. A controlled intervention in reduction of redundant hospital days. International Journal of Epidemiology 1996;25 (3):604-8.

Vian 2003 \{published data only\}

Vian T. Corruption in the health sector in Albania. 2003. Corruption in the health sector in Albania. USAID Corruption Reduction Project in Albania. Washington D.C.: Management Systems International, 2003.

Vian 2005 \{published data only\}

Vian T. Analytical paper on corruption in the health sector. Azerbaijan anti-corruption strategy study. December 2005. http://pdf.usaid.gov/pdf docs/Pnadp872.pdf (accessed 28 July 2016).

Yang 2006 \{published data only\} Yang WS, Hwang SY. A process-mining framework for the detection of healthcare fraud and abuse. Expert Systems with Applications 2006;31(1):56-68.

\section{References to studies awaiting assessment}

Di Tella 2003 \{published data only\} Di Tella R, Schargrodsky E. The role of wages and auditing during a crackdown on corruption in the city of Buenos Aires. Journal of Law and Economics 2003;46(1):269-92.

Dowd 2016 \{published data only\}

Dowd BE, Swenson T, Parashuram S, Coulam R, Kane R. PQRS participation, inappropriate utilization of health care

Interventions to reduce corruption in the health sector (Review) 
services, and Medicare expenditures. Medical Care Research and Review 2016;73(1):106-23.

\section{Randall 2005 \{published data only\}}

Randall ML, Rosenbaum JR, Rohrbaugh RM, Rosenheck RA. Attitudes and behaviors of psychiatry residents toward pharmaceutical representatives before and after an educational intervention. Academic Psychiatry 2005;29(1): 33-9.

Samuel 2015 \{published data only\}

Samuel J, Frisancho A. Rights-based citizen monitoring in Peru: Evidence of impact from the field. Health and Human Rights 2015;17(2):123-34.

\section{Additional references}

\section{Alkhaled 2014}

Alkhaled L, Kahale L, Nass H, Brax H, Fadlallah R, Badr K, et al. Legislative, educational, policy and other interventions targeting physicians' interaction with pharmaceutical companies: a systematic review. BMJ Open 2014;4(7): e004880.

Azfar 2005a

Azfar O, Gurgur T. Does corruption affect health and education outcomes in the Philippines?. The IRIS Discussion Papers on Institutions and Development 2005 May;4(7):1-48.

\section{Azfar 2005b}

Azfar O. Corruption and the delivery of health and educational services. In: Spector BI editor(s). Fighting Corruption in Developing Countries: Strategies and Analysis. Bloomfield, CT: Kumarian Press, 2005:181-212.

\section{Batory 2012}

Batory A. Why do anti-corruption laws fail in Central Eastern Europe? A target compliance perspective. Regulation \& Governance 2012;6(1):66-82.

\section{Black 2016}

Black's Law Dictionary. The Law Dictionary. http:// thelawdictionary.org/corruption/. 8th. Eagan, Minnesota: Thompson West, (Accessed 28 July 2016).

\section{Chereche 2013}

Chereche RM, Ungureanu MI, Sandu P, Rus IA. Defining informal payments in healthcare: a systematic review. Health Policy 2013;110(2-3):105-14.

\section{Chinamo 2007}

Chinamo O, Shumba G. Institutional Working Definition of Corruption. Anti Corruption Trust Southern African Working Paper Series. ACT/1/2007/ WPS. http://archive.kubatana.net/docs/demgg/actsa definition 'of corruption 080731 .pdf (accessed 28 July 2016).

CMS 2015

Centers for Medicare \& Medicaid Services. National Health Expenditure Fact Sheet. https://www.cms.gov/researchstatistics-data-and-systems/statistics-trends-and-reports/ nationalhealthexpenddata/nhe-fact-sheet.html (accessed 28 July 2016).

\section{Cochrane EPOC 2013a}

Cochrane Effective Practice, Organisation of Care (EPOC). What study designs should be included in an EPOC review? EPOC Resources for review authors. http:// epoc.cochrane.org/epoc-specific-resources-review-authors. Oslo: Norwegian Knowledge Centre for the Health Services, (accessed 28 July 2016).

\section{Cochrane EPOC 2013b}

Cochrane Effective Practice, Organisation of Care (EPOC). Synthesising results when it does not make sense to do a meta-analysis. EPOC Resources for review authors. http:// epoc.cochrane.org/epoc-specific-resources-review-authors. Oslo: Norwegian Knowledge Centre for the Health Services, (accessed 28 July 2016).

Cochrane EPOC 2013c

Cochrane Effective Practice, Organisation of Care (EPOC). EPOC worksheets for preparing a Summary of Findings (SoF) table using GRADE. EPOC Resources for review authors. http://epoc.cochrane.org/epoc-specific-resourcesreview-authors. Oslo: Norwegian Knowledge Centre for the Health Services, (accessed 28 July 2016).

\section{Cochrane EPOC 2015}

Cochrane Effective Practice, Organisation of Care (EPOC). Suggested risk of bias criteria for EPOC reviews. EPOC resources for review authors. http://epoc.cochrane.org/ epoc-specific-resources-review-authors. Oslo: Norwegian Knowledge Centre for the Health Services, (accessed 28 July 2016).

\section{Curran 1987}

Curran MA, Curran KE. Gambling away absenteeism. The Journal of Nursing Administration 1987;17(12):28-31.

\section{Danilovik 2007}

Danilovik I. Corruption in an ignored sector: assessing the level of impact of bribery on patients' access to health care and suggesting possible solutions to the problem. 10th International Anti-Corruption Conference. http:// www. 10 iacc.org/content. phtml?documents $=300 \&$ art $=49 \&$ c=danilovik\#notes (accessed 28 July 2016).

Dyer 2006

Dyer O. New Report on corruption in health. Bulletin of the World Health Organization 2006;84(2):84-5.

\section{Ensor 2002}

Ensor T, Duran-Moreno A. Chapter 5: Corruption as a challenge to effective regulation in the health sector. In: Saltman RB, Busse R, Mossialos E (editors). Regulating entrepreneurial behaviour in European health care systems. Open University Press, Buckingham, PA, 2002. http:/ /www.euro.who.int/ ' data/assets/pdf' file/0006/98430/ E74487.pdf (accessed 28 July 2016).

\section{Ensor 2004}

Ensor T. Informal payments for health care in transition economies. Social Science \& Medicine 2004;58(2):237-46.

\section{Factor 2015}

Factor R, Kang M. Corruption and population health outcomes: an analysis of data from 133 countries using

Interventions to reduce corruption in the health sector (Review) 
structural equation modelling. International Journal of Public Health 2015;60(6):633-41. [DOI: 10.1007/ s00038-015-0687-6]

\section{Falkingham 2004}

Falkingham J. Poverty, out-of-pocket payments and access to health care: evidence from Tajikistan. Social Science \& Medicine 2004;58(2):247-58.

\section{FBI 2011}

Federal Bureau of Investigation. Financial Crimes Report to the Public: Fiscal Years 2010-2011. https://www.fbi.gov/ stats-services/publications/financial-crimes-report-20102011/financial-crimes-report-2010-2011\#Health (accessed 28 July 2016).

\section{Fretheim 2015}

Fretheim A, Zhang F, Ross-Degnan D, Oxman AD, Cheyne H, Foy R, et al. A reanalysis of cluster randomized trials showed interrupted time-series studies were valuable in health system evaluation. Journal of Clinical Epidemiology 2015;68(3):324-33.

\section{Gaudine 2001}

Gaudine AP, Saks AM. Effects of an absenteeism feedback intervention on employee absence behavior. Journal of Organizational Behavior 2001;22(1):15-29.

\section{Graycar 2012}

Graycar A, Sidebottom A. Corruption and control: a corruption reduction approach. Journal of Financial Crime 2012;19(4):384-99.

\section{Gupta 2002}

Gupta S, Davoodi HR, Tiongson E. Corruption and the provision of health care and educational services. In: Abed GT, Gupta S editor(s). Governance, Corruption and Economic Performance. Washington DC: International Monetary Fund, 2002:245-72.

\section{Hanf 2011}

Hanf M, Van-Melle A, Fraisse F, Roger A, Carme B, Nacher M. Corruption kills: estimating the global impact of corruption on children deaths. PLoS One 2011;6(11): e26990. [DOI: 10.1371/journal.pone.0026990]

\section{Hanna 2011}

Hanna R, Bishop S, Nadel S, Scheffler G, Durlacher K. The effectiveness of anti-corruption policy. What has worked, what hasn't, and what we don't know-a systematic review. Technical report. http://r4d.dfid.gov.uk/PDF/Outputs/ SystematicReviews/Anti corruption 2011Hanna.pdf. London: EPPI-Centre, SocialScience Research Unit, Institute of Education, University of London, (accessed 28 July 2016).

\section{Higgins 2011}

Higgins JPT, Altman DG, Sterne JAC (editors). Chapter 8: Assessing risk of bias in included studies. In: Higgins JPT, Green S (editors). Cochrane Handbook for Systematic Reviews of Interventions Version 5.1.0 [updated March 2011]. The Cochrane Collaboration, 2011. Available from www.cochrane-handbook.org. The Cochrane Collaboration

\section{Hussmann 2011}

Hussmann K. Addressing corruption in the health sector. Securing equitable access to health care for everyone. January 2011 No. 1. http://www.u4.no/publications/ addressing-corruption-in-the-health-sector-securingequitable-access-to-health-care-for-everyone/ (accessed dd Month yyyy).

\section{Hwong 2014}

Hwong AR, Qaragholi N, Carpenter D, Joffe S, Campbell EG, Soleymani Lehmann L. A systematic review of state and manufacturer physician payment disclosure websites: Implications for implementation of the Sunshine Act. The Journal of Law, Medicine \& Ethics 2014;42(2):208-19.

\section{Johnsøn 2012}

Johnsøn J, Taxell N, Zaum D. Mapping evidence gaps in anti-corruption: assessing the state of the operationally relevant evidence on donors' actions and approaches to reducing corruption. October 2012 No. 7. http:/ /r4d.dfid.gov.uk/PDF/Outputs/U4/U4Issue-2012-07mapping-evidence-web.pdf (accessed 28 July 2016).

\section{Johnsøn 2013}

Johnsøn J, Søreide T. Methods for learning what works and why in anti-corruption. An introduction to evaluation methods for practitioners. August 2013 No. 8. http: //www.u4.no/publications/methods-for-learning-whatworks-and-why-in-anti-corruption-an-introductionto-evaluation-methods-for-practitioners/. Bergen: U4 Anticorruption Resource Centre, (accessed dd Month yyyy).

\section{Joudaki 2014}

Joudaki H, Rashidian A, Minaei-Bidgoli B, Mahmoodi M, Geraili B, Nasiri M, et al. Using data mining to detect health care fraud and abuse: a review of literature. Global Journal of Health Science 2014;7(1):194-202.

\section{Killias 2016}

Killias M, Mugellini G, Isenring GL, Villettaz P. Administrative reforms in the public sector and their impact on the level of corruption: protocol for a systematic review. http://www.campbellcollaboration.org/lib/project/305/ (accessed 28 July 2016).

\section{Kiwanuka 2014}

Kiwanuka SN, Nalwadda C, Pariyo GW, Ssengooba F, Rutebemberwa E. Interventions for managing absenteeism among health workers. Cochrane Database of Systematic Reviews 2014, Issue 9. [DOI: 10.1002/ 14651858.CD009250.pub2]

\section{Lanyi 2005}

Lanyi A, Azfar O. Tools for Assessing Corruption \& Integrity in Institutions. A Handbook. https:/ /www.usaid.gov/sites/default/files/documents/2496/ Tools $\% 20$ for $\% 20$ Assessing $\% 20$ Corruption $\% 20 \% 26 \% 20$ Integrity $\% 20$ in $\% 20$ Instituti (accessed 28 July 2016).

\section{Lectric Law Library 2016}

The Lectric Law Library. The Library's Lexicon. http:// www.lectlaw.com/def/c314.htm (accessed 28 July 2016). 


\section{Lewis 2000}

Lewis M. Who is paying for health care in Eastern Europe and Central Asia?. http://web.worldbank.org/archive/ website00504/WEB/PDF/WHO IS P.PDF (accessed 28 July 2016).

\section{Lewis 2006}

Lewis M. Governance and corruption in public health care systems. Working Paper Number 78. January 2006. http://www1.worldbank.org/publicsector/anticorrupt/ Corruption\%20WP·78.pdf. Washington DC: Center for Global Development, (accessed 28 July 2016).

\section{Li 2000}

Li H, Xu LC, Zou H. Corruption, income distribution, and growth. Economics and Politics 2000;12(2):155-81.

\section{Lindelow 2006}

Lindelow M, Kushnarova J, Kaiser K. Measuring corruption in the health sector: what can we learn from public expenditure tracking and service delivery surveys in developing countries?. In: Transparency International, editor(s). Global Corruption Report 2006: Special Focus on Corruption and Health. London: Pluto Press, 2006.

Lio 2015

Lio MC, Lee MH. Corruption costs lives: a cross-country study using an IV approach. The International Journal of Health Planning and Management 2015;31(2):175-90. [DOI: 10.1002/hpm.2305]

\section{Lynch 2013}

Lynch U, McGrellis S, Dutschke M, Anderson M, Arnsberger P, Macdonald G. What is the evidence that the establishment or use of community accountability mechanisms and processes improves inclusive service delivery by governments, donors and NGOs to communities?. London: Social Science Research Unit, Institute of Education, University of London, 2013.

Molina 2013

Molina E, Pacheco A, Gasparini L, Cruces G, Rius A. Community monitoring to curb corruption and increase access and quality in service delivery in low- and middleincome countries: protocol for a systematic review. http:/ /campbellcollaboration.org/lib/project/261/ (Accessed 28 July 2016).

Muldoon 2011

Muldoon KA, Galway LP, Nakajima M, Kanters S, Hogg RS, Bendavid E, et al. Health system determinants of infant, child and maternal mortality: a cross-sectional study of UN member countries. Globalization and Health 2011; 7:42. [DOI: 10.1186/1744-8603-7-42]

\section{Nadpara 2015}

Nadpara N, Samanta S. An empirical examination of the effect of corruption on health outcomes. https:// business.tcnj.edu/files/2015/07/Nadpara-Thesis-2015revised.pdf. New Jersey: The College of New Jersey, (Accessed 28 July 2016).

\section{Peisakhin 2011}

Peisakhin LV. Field experimentation and the study of corruption. In: Rose-Ackerman S, Søreide T editor(s).
International Handbook on the Economics of Corruption. Vol. 2, Cheltenham: Edward Elgar Publishing Ltd, 2011: 335-55.

\section{Pinzón-Flórez 2015}

Pinzón-Flórez CE, Fernández-Niño JA, Ruiz-Rodríguez M, Idrovo ÁJ, Arredondo López AA. Determinants of performance of health systems concerning maternal and child health: a global approach. PLoS One 2015;10(3): e0120747. [DOI: 10.1371/journal.pone.0120747]

\section{Rashidian 2012}

Rashidian A, Joudaki H, Vian T. No evidence of the effect of the interventions to combat health care fraud and abuse: a systematic review of the literature. PLoS One 2012;7(8): e41988. [DOI: 10.1371/journal.pone.0041988]

\section{Rose-Ackerman 2004}

Rose-Ackerman S. The challenge of poor governance and corruption. Copenhagen Consensus Challenge Paper. 2004. http://www.copenhagenconsensus.com/sites/default/ files/cp-corruptionfinished.pdf (accessed 28 July 2016).

\section{Rose-Ackerman 2012}

Rose-Ackerman S, Truex R. Corruption and policy reform. Working paper prepared for the Copenhagen Consensus Project 2012. http://www.copenhagenconsensus.com/sites/ default/files/workingpaper corruption.pdf. New Haven: Yale Law School, (accessed 28 July 2016).

Ross 2007

Ross JS, Lackner JE, Lurie P, Gross CP, Wolfe S, Krumholz HM. Pharmaceutical company payments to physicians: early experiences with disclosure laws in Vermont and Minnesota. JAMA 2007;297(11):1216-23.

\section{Santhakumar 2015}

Santhakumar S, Adashi EY. The Physician Payment Sunshine Act: testing the value of transparency. JAMA 2015;313(1):23-4.

\section{Savedoff 2006}

Savedoff WD. The causes of corruption in the health sector: a focus on health care systems. Transparency International. Global Corruption Report 2006: Special Focus on Corruption and Health. London: Pluto Press, 2006.

\section{SIDA 2016}

Swedish International Development Cooperation Agency (SIDA). Our work against corruption. http://www.sida.se/ English/how-we-work/approaches-and-methods/our-workagainst-corruption/ (accessed 28 July 2016).

\section{Sparrow 2008}

Sparrow MK. Fraud in the U.S. health care system: exposing the vulnerabilities of automated payments systems. Social Research 2008;75(4):1151-80.

Szende 2006

Szende A, Culyer AJ. The inequity of informal payments for health care: the case of Hungary. Health Policy 2006;75 (3):262-71. 
TI 2006

Transparency International. Global Corruption Report 2006: Special Focus on Corruption and Health. London: Pluto Press, 2006.

U4 2006

U4 Anti-Corruption Resource Centre. Corruption in the Health Sector. http://www.cmi.no/publications/file/2560corruption-in-the-health-sector.pdf (accessed dd Month уууу).

\section{UNDP 2004}

United Nations Development Programme. UNDP Practice Note: Anti-Corruption. http://www.u4.no/recommendedreading/anti-corruption-practice-note/ (accessed 28 July 2016).

\section{USAID 2005}

United States Agency for International Development. USAID Anticorruption Strategy. http://www.u4.no/ recommended-reading/usaid-anticorruption-strategy/ (accessed dd Month yyyy).
Vian 2002

Vian T. Corruption and the health sector. Sectoral Perspectives on Corruption. Vol. 1, Washington D.C.: USAID, 2002:1-7.

Vian 2008

Vian T. Review of corruption in the health sector:theory, methods and interventions. Health Policy and Planning 2008;23(2):83-94.

\section{World Bank 1997}

World Bank. Helping countries combat corruption, the role of the World Bank. September 1997. http:// www1.worldbank.org/publicsector/anticorrupt/corruptn/ corrptn.pdf (accessed 28 July 2016).

\section{References to other published versions of this review}

\section{Gaitonde 2010}

Gaitonde R, Bjørndal A, Oxman AD, Okebukola PO, Ongolo-Zogo P. Interventions to reduce corruption in the health sector. Cochrane Database of Systematic Reviews 2010, Issue 11. [DOI: 10.1002/14651858.CD008856]

* Indicates the major publication for the study 


\section{CHARACTERISTICS OF STUDIES}

\section{Characteristics of included studies [ordered by study ID]}

\section{Germany 2008}

\begin{tabular}{|c|c|c|}
\hline Methods & \multicolumn{2}{|l|}{ Case study } \\
\hline Participants & \multicolumn{2}{|c|}{164 Intensive care physicians in two hospitals (107 and 57 respectively) } \\
\hline Interventions & \multicolumn{2}{|c|}{$\begin{array}{l}\text { Mandatory guidelines that prohibited physicians from accepting benefits in any form } \\
\text { from the pharmaceutical industry }\end{array}$} \\
\hline Outcomes & \multicolumn{2}{|c|}{$\begin{array}{l}\text { Attitudes of physicians towards the pharmaceutical industry (number of advertising gifts } \\
\text { with company logo, belief on influence of companies on prescription behaviour, positive } \\
\text { effect of pharmaceutical guidelines) }\end{array}$} \\
\hline \multicolumn{3}{|l|}{ Notes } \\
\hline \multicolumn{3}{|l|}{ Risk of bias } \\
\hline Bias & Authors' judgement & Support for judgement \\
\hline The basis for case selection was appropriate & Low risk & $\begin{array}{l}\text { "All doctors in intensive care of a hospital with and one without } \\
\text { guidelines were asked anonymously by a questionnaire about } \\
\text { their dealings with the pharmaceutical industry. The response } \\
\text { rate was } 64.9 \%(37 / 57) \text { and } 55.1 \%(59 / 107) \text { respectively. The } \\
\text { cooperation rate in both groups was } 100 \% \text { " }\end{array}$ \\
\hline
\end{tabular}

The time span of the study was long enough Unclear risk to address the core issues fairly

The methods for data collection were ap- Low risk propriate for the purpose of the study

The sources of information were appropri- Low risk ate for the purpose of the study

The methods used to analyse the data were Unclear risk appropriate for the purpose of the study

The methods used to identify explanatory Unclear risk factors were appropriate for the purpose of the study
The study issued questionnaires were issued in May 2008. It was unclear whether or not the timing was sufficient to address the issues effectively

The survey method (to investigate whether hospital doctors with guidelines and those without guidelines differ in their attitude toward the pharmaceutical industry) seems appropriate to respond to the research questions identified

The doctors in the intensive care unit are usually targeted by the pharmaceutical companies so are an appropriate source of information

The comparison between groups was conducted with $\mathrm{P}$ values, confidence intervals (CIs) and relative risk reductions. However, it is unclear if the authors considered other variables which may influence the relationship (e.g. confounders)

It was unclear whether or not the study authors explored further explanatory factors based on the study design 


\section{Germany 2008 (Continued)}

The linkages are transparent between the Low risk data that were reported and inferences
The linkages are quite transparent. As the study authors noted, "hospital guidelines on relations with the pharmaceutical industry appear to further a critical attitude by physicians regarding the pharmaceutical industry"

India 2001-2005

\begin{tabular}{l|l}
\hline Methods & Case study design \\
\hline Participants & $\begin{array}{l}\text { The study covered all the public hospitals in the whole state (province) in the history of } \\
\text { the Karnataka, South India }\end{array}$ \\
\hline Interventions & $\begin{array}{l}\text { The Chief Minister of the State of Karnataka initiated the intervention in } 2001 \text { when } \\
\text { he brought in a well-known retired judge to head the ombudsman's office that was } \\
\text { created and functioning since } 1986 . \text { The Lokayukta and the VDH made the offices more } \\
\text { accessible, and visited every district and subdistrict in the state where they investigated } \\
\text { between } 100 \text { to } 200 \text { complaints every visit. They also extensively used the media and } \\
\text { attempted legal and administrative changes at the state and the national level }\end{array}$ \\
\hline Outcomes & $\begin{array}{l}\text { The study reported on the yearly trend on the number of complaints received, the number } \\
\text { of complaints investigated and the prosecutions and convictions in a given year }\end{array}$ \\
\hline Notes & \\
\hline
\end{tabular}

Risk of bias

\section{Bias}

\section{Authors' judgement Support for judgement}

The basis for case selection was appropriate Low risk The time span of the study was long enough Low risk to address the core issues fairly

\begin{tabular}{l}
\hline $\begin{array}{l}\text { The methods for data collection were ap- } \\
\text { propriate for the purpose of the study }\end{array}$ \\
\hline
\end{tabular}

This was a case study of a particular period in the history of the Ombudsman's office between 2001 and 2006 when there was a new and dynamic leadership. Thus there is no question of selection of case studies

This was a 5-year period and many issues that changed such as increased confidence of the people in the office of the ombudsman, more complaints, more investigations and prosecutions etc. had time to change

There was mainly qualitative data. The only quantitative data presented was regarding the complaints and their status. The methods were inadequate to measure the primary outcomes of the systematic review; however, for the indicators reported, the methods were adequate

There was one "participatory workshop" in November 2006 and 44 semi-structured interviews and 3 field visits to hospitals and a subdistrict health administration service. In addition they docu-
The sources of information were appropri- Low risk ate for the purpose of the study 
India 2001-2005 (Continued)

mented and reported on the status of the number of complaints received in a given year (for a 4-year period), the number of investigation and prosecution initiated, and convictions made

The methods used to analyse the data were Low risk appropriate for the purpose of the study

The methods used to identify explanatory Unclear risk factors were appropriate for the purpose of the study

The linkages are transparent between the Low risk data that were reported and inferences
They conducted a qualitative analysis and used the force-field approach as the basic framework to interpret the results

The study authors did not describe this in detail. There was no description of the process of the analysis and any steps taken to validate the analytic findings

The discussion and inferences flow from the various themes presented in the results

\section{Kyrgyzstan 2001-2010}

Methods

Participants

Outcomes

Interventions

Increasing the transparency of the co-payment system, improving the flow of resources to health care providers, retention of the predominance of general tax financing whilst introducing a new institutional arrangement as the single purchaser of health care services for the whole population

Case study via surveys with sampling methodology designed to obtain estimates significant at the oblast (state/province) and national level in Kyrgyzystan

Kutzin 2001 was based on national survey of 3000 households comprising 12,900 individuals. Baschieri 2006 was based on survey of 3000 households with a sample of 18 , 690 individuals

Falkingham 2010 was based on a survey of 5005 households producing a sample of 21 , 257 individuals

Aleshkina 2011 was based on a survey done in 2010 with 5001 households and 20,225 individuals

Reduce or eliminate out-of-pocket payments incurred by individuals as a result of using healthcare services

Notes

Risk of bias

\section{Bias}

The basis for case selection was appropriate
Authors' judgement

Low risk

\section{Support for judgement}

The study was premised on the reduction of informal payments based on survey results in Kyrgyzystan. The reforms were widereaching and had a number of other reasons for implementation 


\section{Kyrgyzstan 2001-2010 (Continued)}

The time span of the study was long enough Low risk to address the core issues fairly
While the intervention was expanded to the whole country only in 2004 , the studies refer to time points from 2001, 2004, 2007 and 2010. Thus only the studies that reported the findings in 2007 and 2010 had a realistic chance to detect the effect of the intervention

The methods for data collection were ap- Low risk propriate for the purpose of the study

The sources of information were appropri- Low risk ate for the purpose of the study

The methods of data collection were from a household survey with a sample size and sampling design that would provide information significant at the province level

This is an appropriate design given the objective that the study set out to study outof-pocket expenditure and informal payments

The methods used to analyse the data were Unclear risk appropriate for the purpose of the study

The study reported overall all point estimates, but no CIs, tests for trend, or other tests

The methods used to identify explanatory Unclear risk factors were appropriate for the purpose of the study

There was no attempt to derive explanatory factors. The study authors did not report on any relevant data on other factors expected to have an effect on corruption, such as the doctors' salaries, drug availability at the hospital level and amount of money being retained at the health centre level

The linkages are transparent between the Unclear risk data that were reported and inferences
Similar to factors mentioned above

South Korea 2007

Methods

Participants

Interventions
Stratified sampling of 787 clinics without any onsite investigation for false or fraudulent claims between 2001 and 2007

787 out of 800 sample medical clinics under the National Health Insurance system

Medical clinics with no onsite investigations due to false or fraudulent claims to the Health Insurance Review and Assessment Service (HIRA). The enforcement programme was designed to prevent or reduce fraud and abuse of the system based on general deterrence theory, that is, by utilising the fear of penalty to discourage potential false claimants. When healthcare providers anticipated a high risk of detection during the claims review process (the onsite investigations), they were expected to refrain from providing needlessly expensive or medically unnecessary service to patients 
South Korea 2007 (Continued)

\begin{tabular}{|c|c|c|}
\hline Outcomes & \multicolumn{2}{|c|}{ Fear of penalty from a potential onsite investigation and a "costliness index" } \\
\hline Notes & \multicolumn{2}{|l|}{ Survey methodology utilised } \\
\hline \multicolumn{3}{|l|}{ Risk of bias } \\
\hline Bias & Authors' judgement & Support for judgement \\
\hline The basis for case selection was appropriate & Low risk & $\begin{array}{l}\text { The basis was appropriate based on a selec- } \\
\text { tion of } 800 \text { clinics amongst } 15,443 \text { clinics } \\
\text { after stratification }\end{array}$ \\
\hline $\begin{array}{l}\text { The time span of the study was long enough } \\
\text { to address the core issues fairly }\end{array}$ & Low risk & $\begin{array}{l}\text { The time span was sufficient: one month } \\
\text { for the survey and claims from the same } \\
\text { period within } 1 \text { year }\end{array}$ \\
\hline $\begin{array}{l}\text { The methods for data collection were ap- } \\
\text { propriate for the purpose of the study }\end{array}$ & Low risk & $\begin{array}{l}\text { The sampling methodology, questionnaire } \\
\text { and statistical analysis were sufficient }\end{array}$ \\
\hline $\begin{array}{l}\text { The sources of information were appropri- } \\
\text { ate for the purpose of the study }\end{array}$ & Low risk & $\begin{array}{l}\text { The official database from the HIRA was } \\
\text { the source of information }\end{array}$ \\
\hline $\begin{array}{l}\text { The methods used to analyse the data were } \\
\text { appropriate for the purpose of the study }\end{array}$ & Low risk & $\begin{array}{l}\text { The statistical methods were sufficient e. } \\
\text { g. the study authors performed CIs, t-tests } \\
\text { and analysis of variance (ANOVA) }\end{array}$ \\
\hline $\begin{array}{l}\text { The methods used to identify explanatory } \\
\text { factors were appropriate for the purpose of } \\
\text { the study }\end{array}$ & Low risk & $\begin{array}{l}\text { The multiple regression analysis conducted } \\
\text { was appropriate to identify the important } \\
\text { explanatory factors }\end{array}$ \\
\hline $\begin{array}{l}\text { The linkages are transparent between the } \\
\text { data that were reported and inferences }\end{array}$ & Low risk & $\begin{array}{l}\text { The inferences the study authors made } \\
\text { seem to be linked to the data reported }\end{array}$ \\
\hline
\end{tabular}

USA 1993-2001

\begin{tabular}{l|l}
\hline Methods & Case study \\
\hline Participants & $\begin{array}{l}1177 \text { hospitals with subgroup of } 586 \text { hospitals in the Healthcare Cost and Utilization } \\
\text { Project (HCUP) Nationwide Inpatient Sample database who receive reimbursement } \\
\text { from the Centers for Medicare \& Medicaid Services (CMS) }\end{array}$ \\
\hline Interventions & $\begin{array}{l}\text { The paper studied the effect of enforcement of he Health Insurance Portability and Ac- } \\
\text { countability Act of } 1996 \text { (HIPAA) on reduction in upcoding, essentially reducing fraud } \\
\text { by increasing accountability (a law that proscribes prosecution and fines for improper or } \\
\text { fraudulent billing of medical services) }\end{array}$ \\
\hline
\end{tabular}

Outcomes

Increase transparency and accountability, detection and enforcement

Interventions to reduce corruption in the health sector (Review)

Copyright ( 2016 The Authors. Cochrane Database of Systematic Reviews published by John Wiley \& Sons, Ltd. on behalf of The

Cochrane Collaboration. 
USA 1993-2001 (Continued)

Notes

The study authors assessed overbilling by providers of hospital services, which leads to Medicare paying more than is necessary for the particular condition. The study authors identified 17 diagnosis-related groups (DGRs) affected by this practice

\section{Risk of bias}

Bias

The basis for case selection was appropriate Low risk

\section{Authors' judgement Support for judgement}

"Data was drawn for the years 1993- 2001 from the National Healthcare Cost and Utilization Project (HCUP). Both individual hospital data and individual patient discharge data are included in the data set. From each hospital in the dataset, all discharges for a given year are included"

"To maximise sample size, we use all the data available in each year"
The time span of the study was long enough Low risk to address the core issues fairly

The methods for data collection were ap- Low risk propriate for the purpose of the study
The 8 years time-span seems sufficient to address the core issues

"We would prefer to include only hospitals that have data across the entire sample period. However, the sample size would be inadequate under such a requirement. To maximise the sample size, we use all data available in each given year. A limitation of this approach is that the sample for each year includes a different group of hospitals. Therefore, it is possible that an apparent pattern of upcoding over time could be driven by the changing mix of hospitals from year to year. However, we have no reason to believe that HCUPs sample selection procedures would impose a systematic bias on our measure of upcoding"

The sources of information were appropri- Low risk ate for the purpose of the study

"Data was drawn for the years 1993- 2001 from the National Healthcare Cost and Utilization Project (HCUP). Both individual hospital data and individual patient discharge data are included in the data set. From each hospital in the dataset, all discharges for a given year are included"

"To maximise sample size, we use all the data available in each year"

The methods used to analyse the data were Low risk appropriate for the purpose of the study

The multivariate analysis included many factors that the study authors considered important to influence the outcome (upcoding) including for-profit status, ownership status, income in the area of patients served, as a proxy for patients' income, DRG categories, etc

The methods used to identify explanatory Low risk factors were appropriate for the purpose of the study
The methods used to identify the explanatory factors seem satisfactory, but as the study authors noted, "further research would be useful to refine both the dependent and independent measures (variables) used in the study" 
USA 1993-2001 (Continued)

The linkages are transparent between the Unclear risk data that were reported and inferences
The study authors used a surrogate indicator for actual upcoding, which is based on the number of at-risk procedures and not on actually checking the case files, or the discharge summaries, to actually confirm upcoding. This might have been impracticable though, but might affect the inferences

\section{USA 1994-1998}

Methods

Participants
Case study using survey methodology

Elderly Medicare recipients who were hospitalised with 1 or more of 6 types of illness (pneumonia/respiratory infections; chronic obstructive pulmonary disease (COPD)/ general; respiratory infections; circulatory disorders; kidney disorders; diabetes/metabolic disorders; cerebrovascular disorder/stroke) between 1994 and 1998. As the study authors noted, "we restrict our sample to nonfederal hospitals that ever reported providing general medical or surgical services. From the survey we obtain information on hospital ownership type, size, teaching status, system membership, and other characteristics that might affect the incentives of the hospital and its managers"

Enforcement efforts by State Medicare Fraud Control Units (MFCU) aimed at reducing fraud in Medicare

Interventions

Reduction in billing as a measure of previous upcoding, Increase in amount spent in anti-corruption efforts as a surrogate for enforcement, quality-of-care metrics

\section{Risk of bias}

\begin{tabular}{|c|c|c|}
\hline Bias & Authors' judgement & Support for judgement \\
\hline The basis for case selection was appropriate & Low risk & $\begin{array}{l}\text { "Random } 20 \% \text { sample of elderly Medicare ben- } \\
\text { eficiaries hospitalised from } 1994 \text { to } 1998 \text { with } \\
\text { one of six illnesses" }\end{array}$ \\
\hline
\end{tabular}

The time span of the study was long enough Low risk Average of data collected annually over 4 years to address the core issues fairly

The methods for data collection were ap- Low risk propriate for the purpose of the study

The sources of information were appropri- Low risk ate for the purpose of the study
Longitudinal data on health expenditures, days in the hospital and patient outcomes as well as other hospital based data were also matched

The study used comprehensive Medicare, American Hospital Association (AHA) and State MFCU programme data 


\section{USA 1994-1998 (Continued)}

The methods used to analyse the data were Low risk appropriate for the purpose of the study
The study authors used multi-level, statistical modelling techniques to analyse the data, which we considered appropriate

The variables used to model the 4 outcomes were appropriate

Linkages between the results of the data analysis and inferences are apparent

The linkages are transparent between the Low risk data that were reported and inferences

USA 2002-2006

\begin{tabular}{ll} 
Methods & $\begin{array}{l}\text { Uncontrolled case study that described the changes in payments and the use of a "trade } \\
\text { secret" exemption over a 4-year period following enactment of the legislation }\end{array}$ \\
\hline Participants & $\begin{array}{l}\text { 4 years of company disclosures of "non-trade secret gift" or payments made to providers } \\
\text { by companies in Vermont, USA }\end{array}$ \\
\hline Interventions & $\begin{array}{l}\text { State disclosure laws that mandated pharmaceutical companies to disclose gifts and } \\
\text { payments to physicians }\end{array}$
\end{tabular}

Outcomes

Payments by drug companies to physicians and prevalence of payments designated as "trade secrets"

Notes Case study design with no randomisation done

\section{Risk of bias}

\begin{tabular}{|c|c|c|}
\hline Bias & Authors' judgement & Support for judgement \\
\hline The basis for case selection was appropriate & Low risk & $\begin{array}{l}\text { "Because Vermontoffers the most robust, } \\
\text { publicly available data for an in-depth anal- } \\
\text { ysis, with strong provisions for enforcement } \\
\text { and compliance, we analysed } 4 \text { years of data } \\
\text { from this state" }\end{array}$ \\
\hline
\end{tabular}

The time span of the study was long enough Low risk to address the core issues fairly
"We explored the value and distribution of industry gifts and payments to health care providers. We also sought to identify emerging trends in companies' practices. The Vermont disclosures reveal previously unknown details about industry marketing expenditures, provide valuable insight into the impact of gift reporting laws on company behavior, and suggest principles for more effective future legislation." 
USA 2002-2006 (Continued)

The methods for data collection were ap- Low risk propriate for the purpose of the study
“Using Vermont's Access to Public Records Law, we filed requests with the Vermont Attorney General's office for companies' disclosures for July 1, 2002, through June 30, 2006."

"From the Vermont Attorney General's website, we obtained the state's annual reports"

The sources of information were appropri- Low risk ate for the purpose of the study

The methods used to analyse the data were Low risk appropriate for the purpose of the study

The study authors only reported descriptive data. The study authors did not perform statistical analyses. There were no comparison data available

Only limited data were available: types of payments, types of recipients and use of "trade secrets" exemption

the study

The linkages are transparent between the Low risk data that were reported and inferences

The inferences related to total spending by pharmaceutical industry and prevalence of trade secrets are supported by data

USA 2005-2014

\begin{tabular}{ll}
\hline Methods & Case study \\
\hline Participants & $\begin{array}{l}\text { The United States Government mandated the Secretary of Department of Health and } \\
\text { Human Services and the Department of Justice to create a joint task force in } 1996 \text { which } \\
\text { implemented a number of interventions to reduce corruption in the Medicare/Medicaid } \\
\text { programmes. An annual report is submitted to Congress every year. The case study is } \\
\text { based on the annual reports of the Department of Justice and the Secretary of Health } \\
\text { and Human Services from } 2006 \text { to } 2014\end{array}$ \\
\hline
\end{tabular}

Interventions

Health care legislation including each of the following.

1. The Affordable Care Act.

2. Healthcare Fraud Prevention and Enforcement Action Team (HEAT).

3. Senior Medicare Patrols.

4. Public Private Partnership to Prevent Fraud.

Interventions to reduce corruption in the health sector (Review) 
USA 2005-2014 (Continued)

\begin{tabular}{l|l}
\hline Outcomes & $\begin{array}{l}\text { Amount returned to the Medicaid Trust Fund due to the various interventions; number } \\
\text { of cases filed and convictions obtained; number of complaints received and investigated } \\
\text { and the prosecutions and convictions in a given year }\end{array}$ \\
\hline Notes & \\
\hline
\end{tabular}

\section{Risk of bias}

\section{Bias}

Authors' judgement Support for judgement

The basis for case selection was appropriate Low risk

This was a case study of the activities of the joint team/initiative set up by the Secretary of Health and Human Services and the Department of Justice

The time span of the study was long enough Low risk to address the core issues fairly

The study used 10 years of annual reports and other related reports

The methods for data collection were ap- Unclear risk propriate for the purpose of the study

There is no way to independently verify the number attributable to the initiative. These are government reports submitted to Congress so one would presume that they are accurate

The sources of information were appropri- Low risk ate for the purpose of the study

The official reports are appropriate for the purposes of the study

The methods used to analyse the data were Low risk appropriate for the purpose of the study

There was a quantitative analysis of the number of cases filed, convicted and funds recovered, which are appropriate for the purposes of this type of study

The methods used to identify explanatory Unclear risk factors were appropriate for the purpose of

The study authors did not describe this in detail. There was no the study discussion on the process of the analysis and any steps taken to validate the analytic findings

The linkages are transparent between the Low risk data that were reported and inferences

The discussion and inferences flows from the various themes presented in the results section

\section{USA 2006}

\begin{tabular}{ll}
\hline Methods & Cross-sectional study \\
\hline Participants & 634 USA-based community health centres (CHCs) \\
\hline Interventions & $\begin{array}{l}\text { The study examines the differences in internal control practices between non-profit } \\
\text { medical practices that experienced fraud and those that did not }\end{array}$ \\
\hline Outcomes & Incidence of financial fraud \\
\hline
\end{tabular}

Notes

Interventions to reduce corruption in the health sector (Review) 
USA 2006 (Continued)

Risk of bias

\begin{tabular}{|c|c|c|}
\hline Bias & Authors' judgement & Support for judgement \\
\hline The basis for case selection was appropriate & Unclear risk & $\begin{array}{l}\text { It is clear that the study authors did not select cases who expe- } \\
\text { rienced fraud. These were self-reported and then compared to } \\
\text { those who did not experience the outcome (fraud) who served } \\
\text { as controls }\end{array}$ \\
\hline $\begin{array}{l}\text { The time span of the study was long enough } \\
\text { to address the core issues fairly }\end{array}$ & Unclear risk & $\begin{array}{l}\text { There was no time span involved, as the data was collected in a } \\
\text { single period of time via questionnaires }\end{array}$ \\
\hline $\begin{array}{l}\text { The methods for data collection were ap- } \\
\text { propriate for the purpose of the study }\end{array}$ & Unclear risk & $\begin{array}{l}\text { The study authors noted that the survey methods are the most } \\
\text { appropriate for the study design but there is little evidence that } \\
\text { this provides evidence about the role of these systems in pre- } \\
\text { venting fraud }\end{array}$ \\
\hline $\begin{array}{l}\text { The sources of information were appropri- } \\
\text { ate for the purpose of the study }\end{array}$ & Low risk & $\begin{array}{l}\text { The informants were the most financially-informed members of } \\
\text { the company }\end{array}$ \\
\hline $\begin{array}{l}\text { The methods used to analyse the data were } \\
\text { appropriate for the purpose of the study }\end{array}$ & Unclear risk & $\begin{array}{l}\text { It is unclear whether or not the study authors considered other } \\
\text { methods or other methods could be used to provide better in- } \\
\text { ferences }\end{array}$ \\
\hline $\begin{array}{l}\text { The methods used to identify explanatory } \\
\text { factors were appropriate for the purpose of } \\
\text { the study }\end{array}$ & Low risk & $\begin{array}{l}\text { The description of the internal control procedures was exhaus- } \\
\text { tive. These are the "explanatory factors" of fraud-susceptibility }\end{array}$ \\
\hline $\begin{array}{l}\text { The linkages are transparent between the } \\
\text { data that were reported and inferences }\end{array}$ & Unclear risk & $\begin{array}{l}\text { It is unclear whether or not the true incidence of fraud was } \\
\text { documented, as fraud could be going on but undetected. Also, } \\
\text { there was no evidence to show that the internal control systems } \\
\text { are the cause of the "reduced fraud" in these providers. If the } \\
\text { study authors had used more time points, perhaps they would } \\
\text { have been able to show this association }\end{array}$ \\
\hline
\end{tabular}

Abbreviations: $\mathrm{CI}=$ confidence interval

Characteristics of excluded studies [ordered by study ID]

Interventions to reduce corruption in the health sector (Review) 


\begin{tabular}{|c|c|}
\hline Study & Reason for exclusion \\
\hline 3ie 2011 & Not a primary study \\
\hline Aelvoet 2009 & Corruption not an outcome \\
\hline Alcázar 2001 & Absenteeism \\
\hline Banerjee 2007 & Absenteeism \\
\hline Barber 2004 & Corruption not an outcome \\
\hline Barr 2009 & Corruption not an outcome \\
\hline Berge 2012 & Not a primary study \\
\hline Björkman 2007 & Corruption not an outcome \\
\hline Björkman 2009 & Corruption not an outcome \\
\hline Blais 2007 & Not healthcare \\
\hline Brown 2015 & Absenteeism \\
\hline Casey 2011 & Corruption not an outcome \\
\hline Ching 2007 & Corruption not an outcome \\
\hline Cohen 2001 & Study design does not meet criteria for primary or secondary analysis \\
\hline De Jaegere 2009 & Does not describe an intervention \\
\hline EHFCN 2013 & Does not describe an intervention \\
\hline Ferraz 2005 & Not healthcare \\
\hline Ferraz 2009 & Not healthcare \\
\hline García-Prado 2006 & Absenteeism \\
\hline Gatti 2002 & Corruption not an outcome \\
\hline Gee 2011 & Does not describe an intervention \\
\hline Gellar 2008 & Does not describe an intervention \\
\hline Giedion 2001 & Study design does not meet criteria for primary or secondary analysis \\
\hline Gray-Molina 2001 & Study design does not meet criteria for primary or secondary analysis \\
\hline
\end{tabular}


(Continued)

\begin{tabular}{|c|c|}
\hline Greving 2007 & Does not describe an intervention \\
\hline Jaén 2001 & Study design does not meet criteria for primary or secondary analysis \\
\hline Klitgaard 2006 & Not a primary study and not healthcare \\
\hline Lee 1990 & Absenteeism \\
\hline Leidalen 2011 & Study design does not meet criteria for primary or secondary analysis \\
\hline Liou 2008 & Methodology paper \\
\hline Luiselli 2008 & Absenteeism \\
\hline Markowich 1989 & Absenteeism \\
\hline Olken 2007 & Not health care \\
\hline Reinikka 2011 & Not health care \\
\hline Rivers 2005 & Study design does not meet criteria for primary or secondary analysis \\
\hline Schargrodsky 2001 & Study design does not meet criteria for primary or secondary analysis \\
\hline Simoens 2009 & Not health care \\
\hline Soeters 2003 & Study design does not meet criteria for primary or secondary analysis \\
\hline Stephens 1978 & Absenteeism \\
\hline Stover 2001 & Corruption not an outcome \\
\hline UNDP 2011 & Does not describe an intervention \\
\hline Vardi 1996 & Study design does not meet criteria for primary or secondary analysis \\
\hline Vian 2003 & Does not describe an intervention \\
\hline Vian 2005 & Study design does not meet criteria for primary or secondary analysis \\
\hline Yang 2006 & Methodology paper \\
\hline
\end{tabular}




\section{Characteristics of studies awaiting assessment [ordered by study ID]}

\section{Di Tella 2003}

\begin{tabular}{ll}
\hline Methods & Regression analysis \\
\hline Participants & Hospital procurement officers in Buenos Aires \\
\hline Interventions & Increase in wages and auditing \\
\hline Outcomes & Prices paid for basic inputs \\
\hline Notes & \\
\hline
\end{tabular}

Dowd 2016

Methods Difference in differences

Participants Healthcare providers in the USA with meaningful Medicare participation

Interventions Medicare's Physician Quality Reporting System (PQRS)

Outcomes Inappropriate utilization of healthcare services

Notes

\section{Randall 2005}

\begin{tabular}{ll}
\hline Methods & Non-randomised trial \\
\hline Participants & Psychiatry residents at a university-affiliated residency program in the USA \\
\hline Interventions & 1-hour educational intervention \\
\hline Outcomes & Survey of attitudes and behaviours towards pharmaceutical representatives \\
\hline Notes &
\end{tabular}

\section{Samuel 2015}

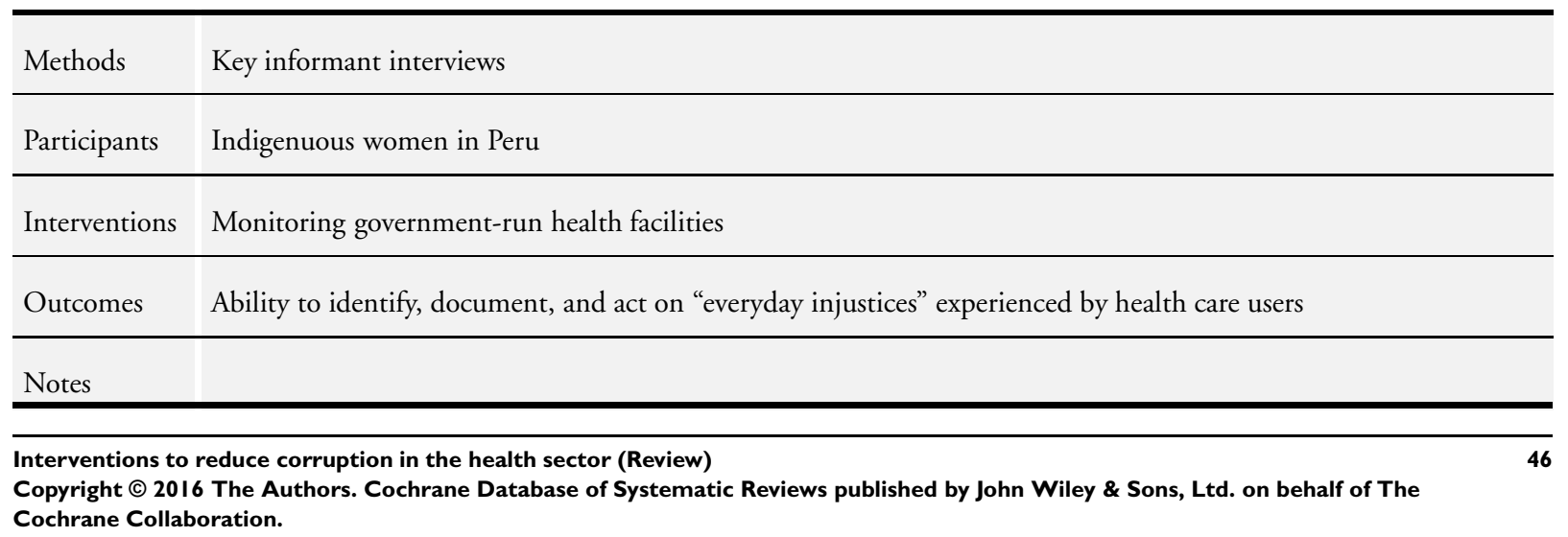




\section{DATA ANDANALYSES}

This review has no analyses.

\section{ADDITIONAL TABLES}

Table 1. Definitions of corruption

\begin{tabular}{l|l}
\hline Source & Definition \\
\hline Anti-Corruption Trust - South Africa (Chinamo 2007) & $\begin{array}{l}\text { "the abuse or complicity in the abuse of private or public power, } \\
\text { office or resources for personal gain" }\end{array}$ \\
\hline Asian Development Bank (Lanyi 2005) & $\begin{array}{l}\text { "Corruption involves behavior on the part of officials in the pub- } \\
\text { lic and private sectors, in which they improperly and unlawfully } \\
\text { enrich themselves or those close to them, or both, or induce others } \\
\text { to do so, by misusing the position in which they are placed" }\end{array}$ \\
\hline
\end{tabular}

Center for the Study of Democracy (Danilovik 2007)

"Corruption is defined as an abuse of power, economical or political, in order to satisfy personal or group interest and endangering the legitimate individual, group, social or state rights and interests.

Southern African Development Community (Chinamo 2007)

"includes bribery or any other behaviour in relation to persons entrusted with responsibilities in the public and private sectors which violates their duties as public officials, private employees, independent agents or other relationships of that kind and aimed at obtaining undue advantage of any kind for themselves or others"

Swedish International Cooperation Development Agency (SIDA "abuse of trust, power or position for improper gain. Corruption 2016) includes, among other things, the offering and receiving of bribes - including the bribery of foreign officials - extortion, conflicts of interest and nepotism."

The Law Dictionary (Black 2016)

"Illegality; a vicious and fraudulent intention to evade the prohibitions of the law. The act of an official or fiduciary person who unlawfully and wrongfully uses his station or character to procure some benefit for himself or for another person, contrary to duty and the rights of others."

The Lectric Law Library’s Lexicon (Lectric Law Library 2016)

"An act done with an intent to give some advantage inconsistent with official duty and the rights of others. It includes bribery, but is more comprehensive; because an act may be corruptly done, though the advantage to be derived from it be not offered by another." 
Table 1. Definitions of corruption (Continued)

Transparency International (TI 2006)

"the abuse of entrusted power for private gain"

"In the health sphere corruption encompasses bribery of regulators and medical professionals, manipulation of information on drug trials, the diversion

of medicines and supplies, corruption in procurement, and overbilling of insurance companies. It is not limited to abuse by public officials, because society frequently entrusts private actors in health care with important public roles."

United Nations Development Programme (UNDP 2004)

"the misuse of public power, office or authority for private benefit - through bribery, extortion, influence peddling, nepotism, fraud, speed money or embezzlement. Although corruption is often considered a sin of government and public servants, it also prevails in the private sector."

United States Agency for International Development (USAID "the abuse of entrusted authority for private gain" 2005)

World Bank (World Bank 1997)

"the abuse of public power for private benefit"

Table 2. Types of corruption in the health sector ${ }^{1}$

\begin{tabular}{|c|c|c|c|}
\hline \multirow[t]{3}{*}{ Types of behaviour } & \multicolumn{3}{|c|}{ Types of interactions or transactions } \\
\hline & $\begin{array}{l}\text { With government regu- } \\
\text { lators }\end{array}$ & \multicolumn{2}{|l|}{ With payers } \\
\hline & $\begin{array}{l}\text { Between government } \\
\text { regulators and suppli- } \\
\text { ers, payers or providers }\end{array}$ & $\begin{array}{l}\text { Between payers and } \\
\text { suppliers }\end{array}$ & $\begin{array}{l}\text { Between payers and } \\
\text { providers }\end{array}$ \\
\hline $\begin{array}{l}\text { Theft (taking resources } \\
\text { without permission or } \\
\text { right) }\end{array}$ & $\begin{array}{l}\text { Collusion in embezzle- } \\
\text { ment (fraudulent appro- } \\
\text { priation of resources) by } \\
\text { government regulators }\end{array}$ & $\begin{array}{l}\text { Embezzlement by sup- } \\
\text { pliers } \\
\text { Not delivering on a con- } \\
\text { tract by suppliers }\end{array}$ & $\begin{array}{l}\text { Embezzlement by man- } \\
\text { agers in provider organi- } \\
\text { sations } \\
\text { Not delivering on a con- } \\
\text { tract by provider organi- } \\
\text { sations } \\
\text { Pilfering of supplies by } \\
\text { health workers } \\
\text { Private use of public fa- } \\
\text { cilities and equipment by } \\
\text { health workers }\end{array}$ \\
\hline
\end{tabular}

Bribes (giving or taking Bribes to obtain regmoney or something else ulatory decisions beneof value to influence a de- fiting suppliers, payers cision for private gain)
Bribes or kickbacks to obtain contracts benefiting suppliers
With patients

Between suppliers or providers and patients
Sale of drugs or supplies that were supposed to be free by health workers

Interventions to reduce corruption in the health sector (Review)

Copyright (C) 2016 The Authors. Cochrane Database of Systematic Reviews published by John Wiley \& Sons, Ltd. on behalf of The

Cochrane Collaboration. 
state capture)

Bribes to obtain accreditation, certification, approval (e.g. drug registration), or inspection results

Policy decisions made to further public officials' or politicians' careers

Politicised appointments ists to referring health workers to induce referrals

Gifts from pharmaceutical companies to physicians

\begin{tabular}{|c|c|c|c|c|}
\hline $\begin{array}{l}\text { Misinformation (falsify- } \\
\text { ing information for pri- } \\
\text { vate gain) }\end{array}$ & $\begin{array}{l}\text { False report- } \\
\text { ing by suppliers, payers } \\
\text { or providers to govern- } \\
\text { ment regulators }\end{array}$ & $\begin{array}{l}\text { Falsifying information to } \\
\text { obtain contracts benefit- } \\
\text { ing suppliers }\end{array}$ & $\begin{array}{l}\text { False insurance claims } \\
\text { Prescription fraud (bo- } \\
\text { gus or forged prescrip- } \\
\text { tions to bill payers) } \\
\text { Absenteeism (spending } \\
\text { less time than contracted } \\
\text { to deliver care) } \\
\text { Misleading drug pro- } \\
\text { motion to prescribers, } \\
\text { including pseudo-trials } \\
\text { used to market drugs }\end{array}$ & $\begin{array}{l}\text { Falsification of creden- } \\
\text { tials by health workers } \\
\text { Supplier-induced or sup- } \\
\text { plier-reduced demand } \\
\text { Misleading pro- } \\
\text { motion of drugs or other } \\
\text { products to patients } \\
\text { Counterfeit or substan- } \\
\text { dard medicines }\end{array}$ \\
\hline
\end{tabular}

${ }^{1}$ The examples of different types of corruption in each cell are not comprehensive.

Table 3. Interventions to reduce corruption

\begin{tabular}{|c|}
\hline $\begin{array}{l}\text { Types of interventions to reduce corrup- } \\
\text { tion }\end{array}$ \\
\hline Disseminate information \\
\hline $\begin{array}{l}\text { Information campaigns aimed at changing } \\
\text { knowledge, attitudes or beliefs about cor- } \\
\text { ruption; or developing skills to address cor- } \\
\text { ruption }\end{array}$ \\
\hline
\end{tabular}

\section{Examples}

Information campaigns that address cognitive factors (knowledge about corruption) or motivational factors (attitudes towards corruption, beliefs about corruption, perceived social norms) underlying corrupt behaviours, or promote skills to reduce corruption (e.g. competence to identify and do something about corruption)

\section{Mechanisms}

Improved knowledge could change perceptions and reduce motivation to behave corruptly or motivate anti-corruption activities (and thereby reduce opportunities). Changes in attitudes could reduce motivation to behave corruptly and motivate anti-corruption activities. Improved competency to identify and do something about corruption
Reduce monopolies

Increase the range of choice of alternative suppliers or providers of specific services
The presence of more than one provider of a service or product may increase the ability to choose providers for specific services which may in turn, limit the motivation to offer bribes or appeasement for the provision of such services
The presence of other options may act as a disincentive to act corruptly apart from potential improvements in quality or efficiency which may occur due to increases in choice 


\section{Reduce incentives}

Remove or reduce incentives or factors that centives motivate corrupt behaviours
Income supplementation, performance in(entives
Increasing income could reduce pressure to behave corruptly
Increase transparency ${ }^{1}$ and accountability $^{2}$

Increase transparency and accountability in decision-making processes; e.g. by increasing stakeholder participation or mandatory documentation of decisions that is open to access
Legislation mandating disclosure of information about decision-making processes or performance, watchdog organisations, activities (or facilitation of activities) by independent agencies, civil society or the mass media to access and disseminate this information, local boards with citizen involvement or open meetings, information systems that link the use of resources to outputs

Redesign of procurement or contracting processes through improving information (to facilitate comparisons), training staff (to solicit and evaluate bids or negotiate contracts), structures to facilitate more open and competitive bidding or contracting processes

\section{Decrease discretion}

Decrease discretion of those who have power

Improve detection and enforcement Improve detection and punishment of corruption
Divide tasks between individuals to create checks and balances, or introduce standard operating procedures

Surveillance, internal security, fraud control, investigation, protection (and rewarding) of whistle-blowers, withholding bonuses if contracts not fulfilled, more severe penalties, less leniency

Credit or background checks
Improved disclosure of information about decision-making processes and performance and increased accountability could reduce motivation to behave corruptly, increase motivation to be involved in anticorruption activities and reduce opportunities for corruption

Better informed competition could reduce opportunities for suppliers or providers to offer bribes or kickbacks or to falsify information

Decreasing the autonomous power of people to make decisions could reduce opportunities for corruption

Improved detection could be a deterrent (reduce motivation) and could reduce opportunity (if punishment includes removing people who behave corruptly from their positions of power)

Those with power may feel pressure to embezzle or accept bribes to pay off personal debts. Ensuring that they do not have excessive debts and could reduce their susceptibility to corruption. Background checks could reduce opportunities to behave corruptly for those at high risk

Leadership and coordination could help to ensure that effective anti-corruption policies are implemented
Establish an independent agency

Establish an anti-corruption agency to coordinate anti-corruption activities
Separate, permanent agencies whose primary function is to provide centralised leadership, coordination or implementation of anti-corruption activities, including any of the above 
${ }^{1}$ Being open in the clear disclosure of information, rules, plans, processes and actions.

${ }^{2}$ Being held responsible for reporting activities and executing powers properly, including responsibility for money or other entrusted property.

Table 4. Results of the included studies

\begin{tabular}{|c|c|c|c|c|}
\hline Study ID $^{1}$ & Type of intervention & Reported effects & Type of study & Interpretation \\
\hline \multicolumn{5}{|c|}{ Disseminate information } \\
\hline Germany 2008 & $\begin{array}{l}\text { Disseminate informa- } \\
\text { tion } \\
\text { One hospital with ex- } \\
\text { plicit guidelines that pro- } \\
\text { hibit hospital doctors } \\
\text { from accepting any form } \\
\text { of benefits from the } \\
\text { pharmaceutical industry } \\
\text { compared to one hospi- } \\
\text { tal without guidelines }\end{array}$ & $\begin{array}{l}\text { Attitudes (of doctors to- } \\
\text { wards pharmaceutical in- } \\
\text { dustry) } \\
\text { Is it acceptable to receive } \\
\text { gifts? } \\
49 \% \text { yes (in hospital with } \\
\text { guideline) } \\
81 \% \text { yes (control). } \\
\text { RR } 0.65,95 \% \text { CI } 0.48 \text { to } \\
0.91 ; P=0.001 \\
\text { Does the pharmaceutical } \\
\text { industry influence your } \\
\text { prescribing? } \\
9 \% \text { yes (guideline) } \\
31 \% \text { yes (control) } \\
\text { RR 3.6, } 95 \% \text { CI } 1.36 \text { to } \\
9.52 \text {; }=0.01\end{array}$ & $\begin{array}{l}\text { Non-ran- } \\
\text { domised, post only study } \\
\text { with data from a survey } \\
\text { of self-reported attitudes } \\
\text { towards the pharmaceu- } \\
\text { tical industry (1 inter- } \\
\text { vention hospital ( } 37 / 57 \\
(65 \%) \text { response rate and } \\
1 \text { control hospital (59/ } \\
107(55 \%) \text { response rate) }\end{array}$ & $\begin{array}{l}\text { Low certainty of the evi- } \\
\text { dence }{ }^{2} \\
\text { Guidelines that prohibit } \\
\text { hospital doctors from ac- } \\
\text { cepting any form of ben- } \\
\text { efits from the pharma- } \\
\text { ceutical industry may } \\
\text { change doctor's attitudes } \\
\text { and their perceptions } \\
\text { of the influence of the } \\
\text { pharmaceutical industry } \\
\text { on their prescribing be- } \\
\text { haviours }\end{array}$ \\
\hline
\end{tabular}

Improve detection and enforcement

\begin{tabular}{|c|c|c|c|c|}
\hline South Korea 2007 & $\begin{array}{l}\text { Improve detection and } \\
\text { enforcement } \\
\text { Onsite investiga- } \\
\text { tion for false and fraud- } \\
\text { ulent claims and penalty } \\
\text { for wrong doers }\end{array}$ & 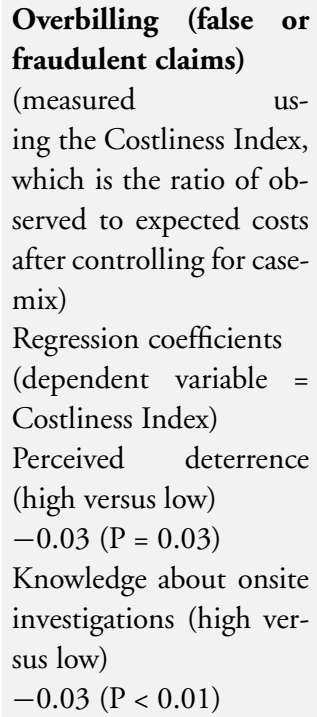 & $\begin{array}{l}\text { Cross-sectional study. } \\
\text { Perceived deterrence was } \\
\text { measured via face-to-face } \\
\text { interviews with the chief } \\
\text { doctor of each clinic }\end{array}$ & $\begin{array}{l}\text { Very low certainty of the } \\
\text { evidence } \\
\text { Clinics whose perceived } \\
\text { deterrence or fear of } \\
\text { penalty attributable to } \\
\text { a potential onsite inves- } \\
\text { tigation is high might } \\
\text { have a lower probabil- } \\
\text { ity of presenting exces- } \\
\text { sive claims than those } \\
\text { whose perceived deter- } \\
\text { rence is low. However, } \\
\text { the certainty of this evi- } \\
\text { dence is very low }\end{array}$ \\
\hline
\end{tabular}

Interventions to reduce corruption in the health sector (Review) 


\begin{tabular}{|c|c|c|}
\hline USA 1994-1998 & $\begin{array}{l}\text { Improve detection and } \\
\text { enforcement } \\
\text { They use variation in } \\
\text { state-level Medicaid en- } \\
\text { forcement to identify the } \\
\text { responsiveness of Medi- } \\
\text { care abuse to enforce- } \\
\text { ment, because of exten- } \\
\text { sive administrative over- } \\
\text { lap between the agen- } \\
\text { cies responsible for polic- } \\
\text { ing the Medicaid and } \\
\text { Medicare. State Medi- } \\
\text { caid } \\
\text { Control Units' expendi- } \\
\text { tures serve as a proxy } \\
\text { for overall anti-fraud en- } \\
\text { forcement efforts }\end{array}$ & $\begin{array}{l}\text { Healthcare } \\
\text { expenditures } \\
\text { The effects of increased } \\
\text { enforcement expendi- } \\
\text { tures on hospital utilisa- } \\
\text { tion and health outcomes } \\
\text { was inconclusive. For ex- } \\
\text { ample, a } 1 \% \text { increase in } \\
\text { expenditures was associ- } \\
\text { ated with a } 0.4 \% \text { increase } \\
\text { in acute care hospital ex- } \\
\text { penditures with a wide } \\
\text { confidence interval } \\
\text { Increased enforce- } \\
\text { ment expenditures were } \\
\text { associated with decreased } \\
\text { expenditures on younger } \\
\text { (age < } 80 \text { ) Medicare pa- } \\
\text { tients } \\
\text { Increased enforcement } \\
\text { expenditures were asso- } \\
\text { ciated with greater de- } \\
\text { clines in acute expendi- } \\
\text { tures for patients who } \\
\text { are initially admitted to a } \\
\text { for-profit hospital, com- } \\
\text { pared to patients initially } \\
\text { admitted to a non-profit } \\
\text { hospital and for patients } \\
\text { admitted to a non-profit } \\
\text { hospital compared to a } \\
\text { public hospital }\end{array}$ \\
\hline
\end{tabular}

Regression analyses using Certainty of the evidence state expenditures on en- Very low ${ }^{4}$

forcement as a measure Greater enforcement of enforcement efforts might lead to a reducwith utilisation, health tion in healthcare expenoutcomes, and health- ditures in patient popucare expenditures as de- lations for whom addipendent variables tional treatment would be of marginal benefit, and the effects might be larger in for-profit hospitals than in non-profit hospitals, and larger in non-profit hospitals than in public hospitals. However, the certainty of this evidence is very low

Establish an independent agency with improved detection and enforcement

India 2001-2005
Establish an independent agency Improve detection and enforcement

Appointment of a wellknown retired judge to head an ombudsman's (Lokayukta) office and his newly appointed Vigilance

Director for Health, Education and Family Welfare (VDH), a newly created post. The ombuds-
Post only time series data Certainty of the evidence (4 years) from a docu- Very low ${ }^{5}$ received

Increased from 1958 the first year to between 7096 and 7732 the following three years

Number of convictions Increased from between 10 and 19 the first 3 years to 41 the last year

Number of convictions in the health sector

1 in the first year and 1
An independent agency with strong leadership and political support, which is responsible for detecting corruption and enforcement, might increase the number of complaints received, but might have little or no impact on the number of convictions in the health 
USA 1993-2001 man and the VDH made the offices more accessible, visited every district and sub-district in the state where they investigated between 100 to 200 complaints every visit, extensively used the media, and attempted legal and administrative changes at the state and the national level in the last year

Establish an independent agency

Improve detection and enforcement

Enforcement of the Health Insurance Portability and Accountability Act of 1996 (HIPAA) , which went into effect 1 January 1997, gave the Office of the Inspector General (OIG) coordination of federal, state and local enforcement efforts against healthcare fraud, including improper coding and billing of Medicare payments and the power to investigate and prosecute offenders. It also raised penalties for healthcare fraud
Overbilling (false or fraudulent claims)

Up-coding = percent of a hospital's total charges that are coded as any of the 17 at-risk diagnosisrelated groups (DRGs) (total and segregated into specific DRGs) which is a measure of overbilling for services rendered Up-coding increased steadily from 1993 to 1997 (by 13\%), levelled off in 1997 and then declined steadily until 2000 and was only slightly lower in 2001

Change in up-coding before and after enforcement of HIPAA

$13.12 \%$ before to 12 . $10 \%$ after

$1.02 \%$ mean decrease (SD 3.03\%)

$0.66 \%$ median decrease

The greater the level of up-coding prior to HIPAA, the more the upcoding was reduced after HIPAA
Regression analysis using Certainty of the evidence the change in up-cod- Very low ${ }^{6}$

ing from before (1993 Establishment of an into 1996) to after enact- dependent agency to inment of HIPAA (1999 to vestigate and enforce ef2001) as the dependent forts against overbilling variable and controlling might lead to a small for hospital characteris- reduction in up-coding. tics (the proportion of However, the certainty of Medicare patients, size, this evidence is very low income, and teaching The lack of decline in upversus non-teaching) coding in 1997 and the steady decline from 1998 to 2001 suggests that the OIG's enforcement actions were necessary to implement HIPAA

Multiple regression analysis suggests that HIPAA had the greatest effect on those hospitals most extensively engaged in upcoding

\begin{tabular}{|c|c|c|c|c|}
\hline USA 2005-2014 & $\begin{array}{l}\text { Establish an indepen- } \\
\text { dent agency } \\
\text { Improve detection and } \\
\text { enforcement } \\
\text { Disseminate informa- }\end{array}$ & $\begin{array}{l}\text { See Table } 5 \\
\text { Enforcement actions } \\
\text { Between } 836 \text { and } 1131 \\
\text { new healthcare fraud } \\
\text { cases per year, and be- }\end{array}$ & $\begin{array}{l}\text { Post-interven- } \\
\text { tion data from DHHS } \\
\text { and DoJ annual reports } \\
\text { to Congress }\end{array}$ & $\begin{array}{l}\text { Certainty of the evidence } \\
\text { High (because of a very } \\
\text { strong association) }{ }^{7} \\
\text { The package of inter- }\end{array}$ \\
\hline
\end{tabular}


tion

Anti-fraud efforts by the Depart-

ment of Health and Human Services (DHHS), the Department of Justice (DoJ), and other agencies were consolidated and strengthened by the

- HIPAA (1996).

Subsequent legislation and executive action included the following

- Senior Medicare

Patrol (Older Americans Act) (1997).

- Healthcare Fraud

Prevention and

Enforcement Action

Team (HEAT) (2009).

- The Affordable

Care Act (2010).

- Public-Private

Partnership to Prevent

Health Care Fraud

(2012).

Activities undertaken by the DHHS, DoJ and other agencies include the following

- Obtaining more sophisticated computer analytic capacity to review payment trends and spot improper billing.

- Stricter healthcare fraud and abuse control laws.

- Prepayment claim checking.

- Manual reviews.

- Educating

providers.

- Provider enrolment

screening.

- Restructuring

programmes. tween 523 and 826 con-

victions per year over the past 10 years

Between 2662 and 4,017

individuals and entities excluded from participation in Medicare, Medicaid, and other federal healthcare programmes per year over the past 10 years

\section{Monetary results}

Between USD 1 and 3 billion per year collected by the Federal government from fraud judgements and settlements over the past 10 years

\section{Return on investment}

Between USD 6.8 and 8. 1 per USD 1 spent over the past 7 years

Estimated programme savings

Between USD 5.5 and 29.8 billion estimated Medicare savings and between USD 0.5 and 12. 3 billion estimated Medicaid savings to the Federal government per year from legislative and administrative actions over the past 10 years ventions coordinated by the DHHS and the DoJ recover a large amount of money and result in hundreds of new healthcare fraud cases and convictions each year. The amount recovered by the Federal government exceeds the amount spent on enforcement efforts

Certainty of the evidence Low ${ }^{8}$

The package of interventions coordinated by the DHHS and the DoJ may result in substantial savings to the Medicare and Medicaid programmes The estimated amount recovered and saved is between $15 \%$ and $55 \%$ of the estimated total amount of fraudulent billings in the USA for 2014 (CMS 2015; FBI 2011).

Interventions to reduce corruption in the health sector (Review) 


\section{Increase transparency}

\begin{tabular}{|c|c|c|c|c|}
\hline Kyrgyzstan 2001-2010 & $\begin{array}{l}\text { Increase transparency } \\
\text { and accountability } \\
\text { By increasing the trans- } \\
\text { parency of the co-pay- } \\
\text { ment system and by } \\
\text { improving the flow of } \\
\text { resources to healthcare } \\
\text { providers, it was hoped } \\
\text { that health financing re- } \\
\text { forms would reduce or } \\
\text { eliminate informal pay- } \\
\text { ments, particularly in } \\
\text { hospitals } \\
\text { Reduce incentives } \\
\text { By changing the struc- } \\
\text { ture of funding (to case- } \\
\text { based payment for in- } \\
\text { patient care and capi- } \\
\text { tation payment for pri- } \\
\text { mary care in 1997) and } \\
\text { by introducing a split } \\
\text { between the purchasers } \\
\text { and providers, as well as } \\
\text { better payment to the } \\
\text { providers, it was hoped } \\
\text { that there would be less } \\
\text { incentive to demand in- } \\
\text { formal payments. New } \\
\text { financial } \\
\text { ments included pool- } \\
\text { ing of all local budget } \\
\text { funds for health, pay- } \\
\text { ment of providers from } \\
\text { these funds, de-linking } \\
\text { the amount of budget } \\
\text { revenues received by a fa- } \\
\text { cility from the number } \\
\text { of beds that it has, and } \\
\text { establishment of an ex- } \\
\text { iicit, formal and differ- } \\
\text { intient care (2001 to }\end{array}$ & $\begin{array}{l}\text { Informal payments } \\
\text { The proportion of peo- } \\
\text { ple who reported they } \\
\text { made other payments in } \\
\text { connection with a con- } \\
\text { sultation } \\
55 \% \text { in } 1994 \\
32 \% \text { in } 2001 \\
17 \% \text { in } 2004 \\
20 \% \text { in } 2007 \\
\text { (there should have been } \\
\text { no other charges after } \\
2004 \text { when the reform } \\
\text { was expanded from } 2 \\
\text { provinces to the whole } \\
\text { country) } \\
\text { The proportion of peo- } \\
\text { ple who reported making } \\
\text { any payment at a family } \\
\text { general practitioner } \\
17 \% \text { in } 2004 \\
13 \% \text { in } 2007 \\
\text { The } \\
\text { tion of patients paying at } \\
\text { a polyclinic/family med- } \\
\text { ical centre } \\
45 \% \text { in } 2004 \\
23 \% \text { in } 2007 \text { (and no one } \\
\text { in } 2007 \text { reported making } \\
\text { a payment for maternity } \\
\text { care) }\end{array}$ & $\begin{array}{l}\text { Before-after data from } \\
\text { national surveys done in } \\
2001,2004,2007 \text { and } \\
2010\end{array}$ & $\begin{array}{l}\text { Certainty of the evidence } \\
\text { Low } 9 \\
\text { A reform that increases } \\
\text { transparency and ac- } \\
\text { countability for co-pay- } \\
\text { ments and reduces incen- } \\
\text { tives for demanding in- } \\
\text { formal payments may re- } \\
\text { duce informal payments }\end{array}$ \\
\hline USA 2002-2006 & $\begin{array}{l}\text { Increase transparency } \\
\text { and accountability } \\
\text { Improve detection and }\end{array}$ & $\begin{array}{l}\text { Pharmaceutical com- } \\
\text { pany spending on gifts } \\
\text { Over } 4 \text { years, total phar- }\end{array}$ & $\begin{array}{l}\text { Postintervention trends } \\
\text { using company disclo- } \\
\text { sure data collected by the }\end{array}$ & $\begin{array}{l}\text { Certainty of the evidence } \\
\text { Very low }{ }^{10} \\
\text { Restrictions on pharma- }\end{array}$ \\
\hline
\end{tabular}




\section{enforcement}

Legislation in Vermont requires pharmaceutical companies to report "the value, nature, and purpose" of gifts to healthcare providers in excess of USD 25. Companies failing to file disclosures face USD 10,000 fines and legal action by the state's Attorney General. The Attorney General's office posts annual reports on the aggregate data on its website maceutical company spending on gifts was not reduced, and some items increased; e.g. speakers' fees quadrupled and gifts of food increased by $51 \%$ Companies increasingly used loopholes in the law (a trade secret provision) to avoid public scrutiny. The proportion of companies using this provision nearly doubled, from $24 \%$ to $42 \%$. The percentage of payments categorised as trade secret increased by one third, from $54 \%$ to $72 \%$

\section{USA 2006}

\begin{tabular}{|c|c|}
\hline $\begin{array}{l}\text { Increase transparency } \\
\text { and accountability } \\
\text { Decrease discretion } \\
\text { The following internal } \\
\text { control practices in com- } \\
\text { munity health centres } \\
\text { (CHCs) were considered } \\
\text { - Check employee } \\
\text { references / job history. } \\
\text { - Require purchase } \\
\text { orders before purchase. } \\
\text { - Board review of } \\
\text { individual expenses. } \\
\text { - Board training in } \\
\text { financial management. } \\
\text { - Job rotation. } \\
\text { - Vacation policies } \\
\text { enforced. } \\
\text { - No presigning of } \\
\text { checks. } \\
\text { - Use stamps for } \\
\text { signatures. } \\
\text { - Bonding } \\
\text { employees. } \\
\text { - Review levels of } \\
\text { bonding. } \\
\text { - Physical security } \\
\text { reviews. } \\
\text { - Issue receipts for } \\
\text { fees. }\end{array}$ & $\begin{array}{l}\text { Mean differences be- } \\
\text { tween CHCs that re- } \\
\text { ported fraud and those } \\
\text { that did not } \\
\text { Frequencies measured on } \\
\text { a scale from } 1 \text { to } 7 \text {. Pos- } \\
\text { itive value indicates in- } \\
\text { ternal control used less } \\
\text { frequently by CHCs that } \\
\text { experienced fraud than } \\
\text { by CHCs that did not } \\
\text { The following internal } \\
\text { control practices were } \\
\text { more reported to be } \\
\text { used more frequently in } \\
\text { CHCs that did not re- } \\
\text { port fraud: } \\
\text { Board training in finan- } \\
\text { cial management } \\
2.49 \text { (P }<0.001) \\
\text { Vacation } \\
\text { enforced } \\
2.819(\mathrm{P}<0.001) \\
\text { Use stamps for signatures } \\
0.515(\mathrm{P}<0.048) \\
\text { Bonding employees } \\
3.102(\mathrm{P}<0.001) \\
\text { Physical security reviews } \\
1.599 \text { (P }<0.001) \\
\text { Issue receipts for fees }\end{array}$ \\
\hline
\end{tabular}

Attorney General's office ceutical company gifts, disclosure and penalties for non-disclosure might not reduce spending on gifts. However, the certainty of this evidence is very low
Certainty of the evidence Very low ${ }^{11}$

The effects of internal control practices on reducing fraud in $\mathrm{CHCs}$ is uncertain. The following might reduce fraud: board training in financial management, enforcement of vacation policies, using stamps for signatures, bonding employees, physical security reviews, issuing receipts for fees, reviewing specification for insurance quotes, entering financial data into records, and receiving and checking purchases

Interventions to reduce corruption in the health sector (Review) 
Table 4. Results of the included studies (Continued)

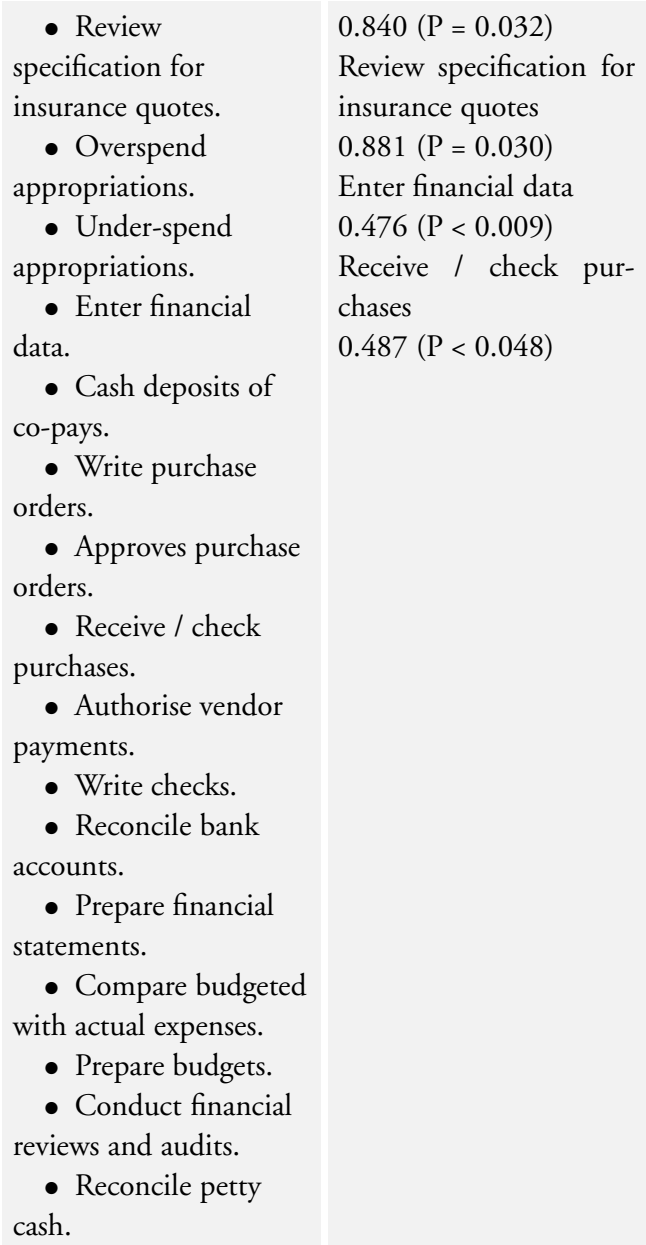

\section{Kyrgyzstan 2001-2010 Increase transparency Informal payments} and accountability

By increasing the transparency of the co-payment system and by improving the flow of resources to healthcare providers, it was hoped that health financing reforms would reduce or eliminate informal payments, particularly in hospitals

\section{Reduce incentives}

By changing the structure of funding (to casebased payment for in-
The proportion of people who reported they made other payments in connection with a consultation

$55 \%$ in 1994

$32 \%$ in 2001

$17 \%$ in 2004

$20 \%$ in 2007

(there should have been no other charges after 2004 when the reform was expanded from 2 provinces to the whole country)

The proportion of peo-
Before-after data from Certainty of the evidence national surveys done in Low $^{11}$

2001, 2004, 2007 and A reform that increases 2010 transparency and accountability for co-payments and reduces incentives for demanding informal payments may reduce informal payments

Interventions to reduce corruption in the health sector (Review) 
Table 4. Results of the included studies (Continued)

\begin{tabular}{|c|c|}
\hline $\begin{array}{l}\text { patient care and capi- } \\
\text { tation payment for pri- } \\
\text { mary care in 1997) and } \\
\text { by introducing a split } \\
\text { between the purchasers } \\
\text { and providers, as well as } \\
\text { better payment to the } \\
\text { providers, it was hoped } \\
\text { that there would be less } \\
\text { incentive to demand in- } \\
\text { formal payments. New } \\
\text { financial arrange- } \\
\text { ments included pool- } \\
\text { ing of all local budget } \\
\text { funds for health, pay- } \\
\text { ment of providers from } \\
\text { these funds, de-linking } \\
\text { the amount of budget } \\
\text { revenues received by a fa- } \\
\text { cility from the number } \\
\text { of beds that it has, and } \\
\text { establishment of an ex- } \\
\text { plicit, formal and differ- } \\
\text { entiated co-payment for } \\
\text { inpatient care (2001-4) }\end{array}$ & $\begin{array}{l}\text { ple who reported making } \\
\text { any payment at a family } \\
\text { general practitioner } \\
17 \% \text { in } 2004 \\
13 \% \text { in } 2007 \\
\text { The propor- } \\
\text { tion of patients paying at } \\
\text { a polyclinic/family med- } \\
\text { ical centre } \\
45 \% \text { in } 2004 \\
23 \% \text { in } 2007 \text { (and no one } \\
\text { in } 2007 \text { reported making } \\
\text { a payment for maternity } \\
\text { care) }\end{array}$ \\
\hline
\end{tabular}

Abbreviations: $\mathrm{CHCs}=$ community health centres; CI = confidence interval; DHHS = Department of Health and Human Services;

DoJ = Department of Justice; DRGs = diagnosis-related groups; HIPAA = Health Insurance Portability and Accountability Act of 1996; OIG = Office of the Inspector General; RR = risk ratio; SD = standard deviation; VDH = Vigilance Director for Health, Education and Family Welfare

${ }^{1}$ Country and years when data were collected.

${ }^{2}$ One small non-randomised study.

${ }^{3}$ Associations from a cross-sectional study of associations between chief doctors' perspectives and an index that suggests overbilling.

${ }^{4}$ Regression analyses using a proxy measure for enforcement with multiple explanatory factors.

${ }^{5}$ One case study with only post-intervention data, without a comparison.

${ }^{6}$ Regression analysis using before-and-after data to estimate the change in up-coding, imprecision.

${ }^{7}$ The monetary results, return on investment and enforcement actions can be attributed to the package of interventions. However, the extent to which these outcomes can be attributed to any specific intervention, including the HIPAA, which consolidated and strengthened anti-fraud efforts, is uncertain.

${ }^{8}$ The methods used to estimate the programme savings are not clearly described and the reported savings vary from year to year.

${ }^{9}$ One non-randomised study.

${ }^{10}$ One study with postintervention data only, based on information disclosed by pharmaceutical companies, with no comparison.

${ }^{11}$ One cross-sectional study with $20 \%$ response rate. There were multiple comparisons. 
Table 5. US Department of Health and Human Services and Department of Justice Health Care Fraud and Abuse Control Program Annual Reports 2005 to 2014

\begin{tabular}{|c|c|c|c|c|c|c|c|}
\hline \multirow[t]{2}{*}{ Year } & \multirow{2}{*}{$\begin{array}{l}\begin{array}{l}\text { Monetary re- } \\
\text { sults }^{1}\end{array} \\
\text { USD billion }^{3}\end{array}$} & \multirow{2}{*}{$\begin{array}{l}\begin{array}{l}\text { Return on in- } \\
\text { vestment }\end{array} \\
\text { Per USD } 1 \text { ex- } \\
\text { pended }^{4}\end{array}$} & \multicolumn{3}{|c|}{ Enforcement actions } & \multicolumn{2}{|c|}{ Estimated programme savings ${ }^{2}$} \\
\hline & & & New cases & Convictions & Exclusions $^{5}$ & $\begin{array}{l}\text { Medicare (USD } \\
\text { billion) }\end{array}$ & $\begin{array}{l}\text { Medicaid (USD } \\
\text { billion) }\end{array}$ \\
\hline 2005 & 1.5 & Not reported & 935 & 523 & 3804 & 22.9 & 7.5 \\
\hline 2006 & 2.2 & Not reported & 836 & 547 & 3422 & 25.5 & 8.5 \\
\hline 2007 & 1.8 & Not reported & 878 & 560 & 3308 & 29.8 & 9.2 \\
\hline 2008 & 1 & USD 4 & 957 & 588 & 3129 & 6.7 & 10 \\
\hline 2009 & 1.6 & Not reported & 1014 & 583 & 2556 & 5.5 & 11.0 \\
\hline 2010 & 2.5 & USD 6.8 & 1116 & 726 & 3340 & 9.4 & 11.6 \\
\hline 2011 & 2.4 & USD 7.2 & 1110 & 743 & 2662 & 7.5 & 12.3 \\
\hline 2012 & 3.0 & USD 7.9 & 1131 & 826 & 3131 & 8 & 0.5 \\
\hline 2013 & 2.6 & USD 8.1 & 1013 & 718 & 3214 & 18.5 to 19.4 & 0.8 \\
\hline 2014 & 2.3 & USD 7.7 & 924 & 734 & 4017 & 14.4 to 15.7 & 1.3 \\
\hline
\end{tabular}

${ }^{1}$ Amount won or negotiated by the Federal government in healthcare fraud judgments and settlements.

${ }^{2}$ Potential savings to the Federal government from legislative and administrative actions. Estimated by third parties, such as the Congressional Budget Office, in 2013 and 2014.

${ }^{3}$ This figure was not adjusted for inflation.

${ }^{4}$ Estimated amount won by the Federal government per USD 1 spent. Three-year averages reported from 2010 to 2014.

${ }^{5}$ Individuals and entities excluded from participation in Medicare, Medicaid and other federal healthcare programmes 
A P P E N D I CES

\section{Appendix I. Search strategies}

\section{CENTRAL (the Cochrane Library)}

\begin{tabular}{|c|c|c|}
\hline \# & Searches & Results \\
\hline$\# 1$ & $\begin{array}{l}\text { MeSH descriptor: [Fraud] this term only and with qualifier(s) } \\
: \text { [Prevention \& control - PC] }\end{array}$ & 0 \\
\hline$\# 2$ & $\begin{array}{l}\text { (anticorrupt* or anti next corrupt* }{ }^{*} \text { or antifraud* or anti next } \\
\left.\text { fraud }^{*}\right): t i, a b, k w\end{array}$ & 0 \\
\hline \#3 & $\left(\right.$ corrupt $^{*}$ or fraud $\left.{ }^{*}\right): t i, a b, k w$ and fight*:ti,ab,kw & 0 \\
\hline \#4 & $(\# 1$ or $\# 2$ or \#3) & 0 \\
\hline$\# 5$ & MeSH descriptor: [Fraud] this term only & 2 \\
\hline \#6 & $\begin{array}{l}\text { (fraud* or corrupt* or bribe or bribes or bribery or forgery or } \\
\text { swindle or swindling):ti,ab,kw }\end{array}$ & 61 \\
\hline \#7 & MeSH descriptor: [Absenteeism] this term only & 403 \\
\hline \#8 & absenteeism:ti,ab,kw & 648 \\
\hline \#9 & MeSH descriptor: [Theft] this term only & 7 \\
\hline \#10 & (theft* or stealing):ti,ab,kw & 105 \\
\hline \#11 & MeSH descriptor: [Quackery] this term only & 2 \\
\hline \#12 & quackery:ti,ab,kw & 5 \\
\hline \#13 & $\begin{array}{l}\text { (health next service* or health next care next service* or health- } \\
\text { care next service* or procedure }{ }^{*} \text { near } / 3 \text { (misus* or abus* or } \\
\text { overuse or over next use or overutilization or over next utiliza- } \\
\text { tion):ti,ab,kw }\end{array}$ & 116 \\
\hline \#14 & $\left(\right.$ misus* $^{*}$ or abus*) near/3 (power* or authority):ti,ab,kw & 2 \\
\hline \#15 & nepotism:ti,ab,kw & 0 \\
\hline \#16 & $\begin{array}{l}\text { (professional* or personnel or physician* or doctor* or nurse*) } \\
\text { near } / 3 \text { misconduct:ti,ab,kw }\end{array}$ & 4 \\
\hline
\end{tabular}

Interventions to reduce corruption in the health sector (Review) 


\section{(Continued)}

\begin{tabular}{|c|c|c|}
\hline \#17 & embezzl*:ti,ab,kw & 0 \\
\hline \#18 & (collusion or collude or colluded):ti,ab,kw & 0 \\
\hline \#19 & pilfering:ti,ab,kw & 0 \\
\hline$\# 20$ & 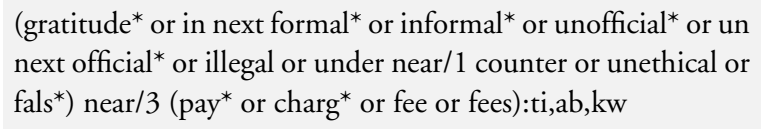 & 5 \\
\hline \#21 & $\left(\mathrm{fee}^{*}\right.$ near/3 split $\left.{ }^{*}\right): \mathrm{ti}, \mathrm{ab}, \mathrm{kw}$ & 2 \\
\hline \#22 & extortion*:ti,ab,kw & 0 \\
\hline \#23 & kickbacks:ti,ab,kw & 1 \\
\hline \#24 & (fals* near/3 information*):ti,ab,kw & 20 \\
\hline$\# 25$ & $\begin{array}{l}\text { (misleading or unethical or dishonest or fals* or illegal) near/ } \\
3 \text { promot* }^{*} \mathrm{ti}, \mathrm{ab}, \mathrm{kw}\end{array}$ & 6 \\
\hline \#26 & pseudo next (trial or trials or study or studies):ti,ab,kw & 2 \\
\hline \#27 & (fals* or dishonest) near $/ 3$ credential*:ti,ab,kw & 0 \\
\hline \#28 & supplier next induced next demand*:ti,ab,kw & 1 \\
\hline \#29 & (gaming near/1 system or gaming near/1 systems):ti,ab,kw & 11 \\
\hline \#30 & state next capture:ti,ab,kw & 0 \\
\hline \#31 & inappropriate next influence*:ti,ab,kw & 1 \\
\hline \#32 & counterfeit:ti,ab,kw & 0 \\
\hline \#33 & $\begin{array}{l}\text { (overprovision or over next provision or underprovision or un- } \\
\text { der next provision or overbilling or over next billing or under- } \\
\text { billing or under next billing):ti,ab,kw }\end{array}$ & 4 \\
\hline \#34 & inducement*ti,ab,kw & 51 \\
\hline \#35 & $\begin{array}{l}(\# 5 \text { or } \# 6 \text { or } \# 7 \text { or } \# 8 \text { or } \# 9 \text { or } \# 10 \text { or } \# 11 \text { or } \# 12 \text { or } \# 13 \text { or } \# \\
14 \text { or } \# 15 \text { or } \# 16 \text { or } \# 17 \text { or } \# 18 \text { or } \# 19 \text { or } \# 20 \text { or } \# 21 \text { or } \# 22 \\
\text { or } \# 23 \text { or } \# 24 \text { or } \# 25 \text { or } \# 26 \text { or } \# 27 \text { or } \# 28 \text { or } \# 29 \text { or } \# 30 \text { or } \\
\# 31 \text { or } \# 32 \text { or } \# 33 \text { or } \# 34)\end{array}$ & 1041 \\
\hline
\end{tabular}

\#36 MeSH descriptor: [Government Regulation] this term only 
(Continued)

\begin{tabular}{|c|c|c|}
\hline$\# 37$ & MeSH descriptor: [Social Control, Formal] this term only & 29 \\
\hline \#38 & MeSH descriptor: [Legislation as Topic] this term only & 8 \\
\hline \#39 & MeSH descriptor: [Public Policy] this term only & 47 \\
\hline \#40 & MeSH descriptor: [Punishment] this term only & 74 \\
\hline \#41 & MeSH descriptor: [Whistleblowing] this term only & 0 \\
\hline \#42 & $\begin{array}{l}\text { (regulat* or law or laws or lawsuit* or legislat* or policy or } \\
\text { policies or whistleblow* or whistle next blow* or prevent* or } \\
\text { reduc* or minimis* or minimiz* or transpare* or accountab* } \\
\text { or discretion* or detect* or enforce* or surveillance or con- } \\
\text { dition* or campaign* or watchdog* or agency or agencies or } \\
\text { background near/2 check or background near/ } 2 \text { credit):ti,ab, } \\
\mathrm{kw}\end{array}$ & 257619 \\
\hline \#43 & $(\# 36$ or $\# 37$ or $\# 38$ or $\# 39$ or $\# 40$ or \#41 or \#42) & 257648 \\
\hline \#44 & $\# 35$ and \#43 & 556 \\
\hline \#45 & $\begin{array}{l}\text { MeSH descriptor: [Drug Industry] this term only and with } \\
\text { qualifier(s): [Ethics - ES] }\end{array}$ & 0 \\
\hline \#46 & $\begin{array}{l}\text { MeSH descriptor: [Drug Labeling] this term only and with } \\
\text { qualifier(s): [Ethics - ES] }\end{array}$ & 0 \\
\hline \#47 & $\# 4$ or \#44 or \#45 or \#46 in Trials & 491 \\
\hline
\end{tabular}

\section{MEDLINE In-Process \& Other Non-Indexed Citations and MEDLINE (Ovid)}

\begin{tabular}{|c|c|c|}
\hline$\#$ & Searches & Results \\
\hline 1 & Fraud/pc [Prevention \& Control] & 1235 \\
\hline 2 & (anticorrupt* or anti corrupt* or antifraud* or anti fraud $\left.{ }^{*}\right)$. tw & 118 \\
\hline 3 & $\left(\left(\right.\right.$ corrupt $^{*}$ or fraud $\left.{ }^{*}\right)$ and fight $\left.{ }^{*}\right)$. tw. & 112 \\
\hline 4 & or/1-3 & 1393 \\
\hline 5 & Fraud/ & 6305 \\
\hline
\end{tabular}

Interventions to reduce corruption in the health sector (Review) 


\section{(Continued)}

6 (fraud* ${ }^{*}$ or corrupt* or bribe or bribes or bribery or forgery or 6162 swindle or swindling).tw

\begin{tabular}{lll}
\hline 7 & Absenteeism/ & 7113 \\
\hline 8 & absenteeism.tw. & 3635 \\
\hline 9 & Theft/ & 1395 \\
\hline 10 & (theft? or stealing).tw. & 1542 \\
\hline 11 & Quackery/ & 1549 \\
\hline 12 & quackery.tw. & 494 \\
\hline 13 & Drug Industry/es [Ethics] & 1461 \\
\hline 14 & Drug Labeling/es [Ethics] & 20 \\
\hline
\end{tabular}

15 ((health service? or health care service? or healthcare service? or 470 procedure?) adj3 (misus* or abus* or overuse or overutilization) ).tw

16 ((misus* or abus*) adj3 (power? or authority)).tw.

17 nepotism.tw.

18 ((professional? or personnel or physician? or doctor? or nurse? 238 ) $\operatorname{adj} 3$ misconduct).tw

19 embezzl*.tw. $\quad 91$

20 (collusion or collude or colluded).tw. 292

21 pilfering.tw. 28

22 ((gratitude? or in formal* ${ }^{*}$ or informal* or unofficial* ${ }^{*}$ or un 238 official $^{*}$ or illegal or under the counter or unethical or fals*) adj3 (pay* or charg* or fee?)).tw

23 (fee? adj3 (split or splitting)).tw. 92

\begin{tabular}{ll}
24 extortion*.tw. & 73 \\
\hline
\end{tabular}

25 kickbacks.tw.

26 (fals* adj3 information?).tw. $\quad 279$ 


\section{(Continued)}

27 ((misleading or unethical or dishonest or fals* or illegal) adj3 113 promot*).tw

28 (pseudo adj (trial? or study or studies)).tw. 8

29 ((fals* or dishonest) adj3 credential?).tw. 5

\begin{tabular}{ll}
\hline 30 supplier induced demand?.tw. & 52 \\
\hline
\end{tabular}

31 gaming the system?.tw. $\quad 48$

32 state capture.tw. $\quad 14$

33 inappropriate influence?.tw. $\quad 14$

$\begin{array}{ll}34 \text { counterfeit.tw. } & 567\end{array}$

35 (overprovision or over provision or underprovision or under 136 provision or overbilling or over billing or underbilling or under billing).tw

\begin{tabular}{|c|c|c|}
\hline 36 & inducement?.tw. & 1055 \\
\hline 37 & or/5-36 & 28527 \\
\hline 38 & Government Regulation/ & 17158 \\
\hline 39 & regulat*.tw. & 1195936 \\
\hline 40 & Social Control, Formal/ & 11028 \\
\hline 41 & Legislation as Topic/ & 15342 \\
\hline 42 & (law? or lawsuit? or legislat*).tw. & 105852 \\
\hline 43 & Public Policy/ & 27515 \\
\hline 44 & (policy or policies).tw. & 139705 \\
\hline 45 & Punishment/ & 4236 \\
\hline 46 & (punish* or penalty or penalties).tw. & 11676 \\
\hline 47 & Whistleblowing/ & 859 \\
\hline
\end{tabular}

48 (whistleblow* or whistle blow*).tw. 575 
(Continued)

\begin{tabular}{|c|c|c|}
\hline 49 & prevent*.tw. & 914747 \\
\hline 50 & reduc*.tw. & 2127715 \\
\hline 51 & $\left(\right.$ minimis* or minimiz $\left.{ }^{*}\right) . t w$. & 118642 \\
\hline 52 & transpare*.tw. & 24570 \\
\hline 53 & accountab*.tw. & 10583 \\
\hline 54 & discretion*.tw. & 4066 \\
\hline 55 & detect* $^{*}$.tw. & 1578007 \\
\hline 56 & enforce*.tw. & 15751 \\
\hline 57 & surveillance.tw. & 98946 \\
\hline 58 & condition*.tw. & 1326447 \\
\hline 59 & ((background or credit) adj2 check).tw. & 35 \\
\hline 60 & campaign*.tw. & 26461 \\
\hline 61 & watchdog?.tw. & 326 \\
\hline 62 & (agency or agencies).tw. & 50149 \\
\hline 63 & or/38-62 & 6185644 \\
\hline 64 & 37 and 63 & 10298 \\
\hline 65 & randomized controlled trial.pt. & 359830 \\
\hline 66 & random*.tw. & 680085 \\
\hline 67 & intervention*.tw. & 522175 \\
\hline 68 & control*.tw. & 2511842 \\
\hline 69 & evaluat*.tw. & 2114842 \\
\hline 70 & effect*.tw. & 4554201 \\
\hline 71 & impact.tw. & 470103 \\
\hline 72 & (time series or time point?).tw. & 76308 \\
\hline
\end{tabular}

Interventions to reduce corruption in the health sector (Review)

Copyright $\odot 2016$ The Authors. Cochrane Database of Systematic Reviews published by John Wiley \& Sons, Ltd. on behalf of The

Cochrane Collaboration. 
(Continued)

\begin{tabular}{|c|c|c|}
\hline 73 & repeated measur*.tw. & 25616 \\
\hline 74 & or/ $65-73$ & 7803416 \\
\hline 75 & case reports.pt. & 1651046 \\
\hline 76 & Case-Control Studies/ & 171322 \\
\hline 77 & $\begin{array}{l}\text { (case study or case studies or case control stud* or case report? } \\
\text { ).tw }\end{array}$ & 341852 \\
\hline 78 & or/75-77 & 1928384 \\
\hline 79 & 74 or 78 & 9310541 \\
\hline 80 & exp Animals/ & 16943522 \\
\hline 81 & Humans/ & 13078281 \\
\hline 82 & 80 not $(80$ and 81$)$ & 3865241 \\
\hline 83 & review.pt. & 1821160 \\
\hline 84 & meta analysis.pt. & 43391 \\
\hline 85 & news.pt. & 157492 \\
\hline 86 & comment.pt. & 563532 \\
\hline 87 & editorial.pt. & 342378 \\
\hline 88 & cochrane database of systematic reviews.jn. & 9693 \\
\hline 89 & comment on.cm. & 563531 \\
\hline 90 & (systematic review or literature review).ti. & 46023 \\
\hline 91 & or/82-90 & 6473169 \\
\hline 92 & 79 not 91 & 6600507 \\
\hline 93 & 64 and 92 & 4481 \\
\hline 94 & 4 or 93 & 5737 \\
\hline 95 & $\left(201112^{*}\right.$ or $2012^{*}$ or $2013^{*}$ or $\left.2014^{*}\right)$.dc,ed,ep,yr. & 2533501 \\
\hline 96 & 94 and 95 & 1041 \\
\hline
\end{tabular}

Interventions to reduce corruption in the health sector (Review)

Copyright $\odot 2016$ The Authors. Cochrane Database of Systematic Reviews published by John Wiley \& Sons, Ltd. on behalf of The

Cochrane Collaboration. 


\section{PubMed alert}

("Fraud/prevention and control"[Mesh] OR anticorrupt*[tiab] OR anti corrupt*[tiab] OR antifraud*[tiab] OR anti fraud*[tiab] OR ((corrupt* ${ }^{*}$ tiab] OR fraud*[tiab]) AND fight*[tiab])) OR ((((randomized controlled trial[pt] OR case reports[pt] OR "Case-Control Studies"[Mesh:noexp]) OR (random*[tiab] OR intervention*[tiab] OR control[tiab] OR controlled[tiab] OR evaluat*[tiab] OR effect[tiab] OR impact[tiab] OR time series[tiab] OR time point*[tiab] OR repeated measure*[tiab] OR case study[tiab] OR case studies[tiab] OR case control study[tiab] OR case control studies[tiab] OR case report[tiab] OR case reports[tiab])) NOT (“Animals”[Mesh] NOT “Humans”[Mesh])) AND ((“Fraud”[Mesh] OR “Absenteeism”[Mesh] OR “Theft”[Mesh] OR “Quackery”[Mesh] OR “Drug Industry/ethics”[Mesh] OR “Drug Labeling/ethics”[Mesh]) OR (fraud*[tiab] OR corrupt*[tiab] OR bribe[tiab] OR bribes[tiab] OR bribery[tiab] OR forgery[tiab] OR swindle[tiab] OR swindling[tiab] OR absenteeism[tiab] OR theft[tiab] OR thefts[tiab] OR stealing[tiab] OR quackery[tiab] OR nepotism[tiab] OR embezzle*[tiab] OR collusion[tiab] OR collude[tiab] OR colluded[tiab] OR pilfering[tiab] OR extortion*[tiab] OR kickbacks[tiab] OR pseudo trial[tiab] OR pseudo trials[tiab] OR pseudo study[tiab] OR pseudo studies[tiab] OR supplier induced demand[tiab] OR supplier induced demands[tiab] OR gaming the system[tiab] OR gaming the systems[tiab] OR state capture[tiab] OR inappropriate influence[tiab] OR counterfeit[tiab] OR overprovision[tiab] OR over provision[tiab] OR underprovision[tiab] OR under provision[tiab] OR overbilling[tiab] OR over billing[tiab] OR underbilling[tiab] OR under billing[tiab] OR inducement*[tiab]) OR ((health service[tiab] OR health services[tiab] OR health care service[tiab] OR health care services[tiab] OR healthcare service[tiab] OR healthcare services[tiab] OR procedure*[tiab]) AND (misus*[tiab] OR abus*[tiab] OR overuse[tiab] OR overutilization[tiab])) OR ((misus*[tiab] OR abus*[tiab]) AND (power[tiab] OR powers[tiab] OR authority[tiab])) OR ((professional*[tiab] OR personnel[tiab] OR physician*[tiab] OR doctor*[tiab] OR nurse*[tiab]) AND misconduct[tiab]) OR ((gratitude*[tiab] OR in formal[tiab] OR informal*[tiab] OR unofficial*[tiab] OR un official[tiab] OR illegal[tiab] OR under the counter[tiab] OR unethical[tiab] OR fals*[tiab]) AND (pay*[tiab] OR charg*[tiab] OR fee[tiab] OR fees[tiab])) OR ((fee[tiab] OR fees[tiab]) AND (split[tiab] OR splitting[tiab])) OR (false information[tiab] OR falsified information[tiab] OR falsify information[tiab]) OR ((misleading[tiab] OR unethical[tiab] OR dishonest[tiab] OR fals*[tiab] OR illegal[tiab]) AND promot*[tiab]) OR ((fals*[tiab] OR dishonest[tiab]) AND credential*[tiab])) AND ((“Government Regulation”[Mesh] OR “Social Control, Formal"[Mesh:noexp] OR “Legislation as Topic”[Mesh:noexp] OR "Public Policy”[Mesh:noexp] OR "Punishment”[Mesh] OR "Whistleblowing”[Mesh]) OR (regulat*[tiab] OR law[tiab] OR laws[tiab] OR lawsuit*[tiab] OR law suit*[tiab] OR legislat*[tiab] OR policy[tiab] OR policies[tiab] OR punish*[tiab] OR penalty[tiab] OR penalties[tiab] OR whistleblow*[tiab] OR whistle blow*[tiab] OR prevent*[tiab] OR reduce[tiab] OR reduction*[tiab] OR reducing[tiab] OR reduced[tiab] OR minimis*[tiab] OR minimiz*[tiab] OR transpare*[tiab] OR accountab*[tiab] OR discretion*[tiab] OR detect*[tiab] OR enforce*[tiab] OR surveillance[tiab] OR condition*[tiab] OR campaign*[tiab] OR watchdog*[tiab] OR agency[tiab] OR agencies[tiab]) OR (background credit*[tiab] OR back ground credit*[tiab] OR background $\operatorname{check}^{*}\left[\right.$ tiab] OR back ground $\operatorname{check}^{*}[$ tiab])))

\section{EMBASE (Ovid)}

\begin{tabular}{|c|c|c|}
\hline$\#$ & Searches & Results \\
\hline 1 & forgery/pc [Prevention] & 869 \\
\hline 2 & $\begin{array}{l}\text { (anticorrupt }{ }^{*} \text { or anti corrupt* or antifraud* or anti fraud* or } \\
\text { antibrib* }^{*} \text { or anti brib* or anti forgery or antiforgery).tw }\end{array}$ & 145 \\
\hline 3 & 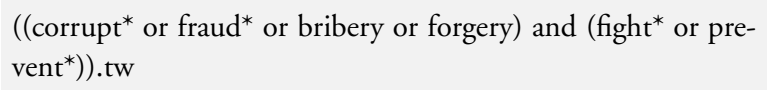 & 589 \\
\hline 4 & or/1-3 & 1507 \\
\hline 5 & Randomized Controlled Trial/ & 365165 \\
\hline 6 & Controlled Clinical Trial/ & 408752 \\
\hline
\end{tabular}

Interventions to reduce corruption in the health sector (Review) 


\section{(Continued)}

\begin{tabular}{|c|c|c|}
\hline 7 & Quasi Experimental Study/ & 1716 \\
\hline 8 & Pretest Posttest Control Group Design/ & 193 \\
\hline 9 & Time Series Analysis/ & 13262 \\
\hline 10 & Experimental Design/ & 8977 \\
\hline 11 & Multicenter Study/ & 117683 \\
\hline 12 & (randomis* or randomiz* or randomly).ti,ab. & 712204 \\
\hline 13 & groups.ab. & 1664349 \\
\hline 14 & $\begin{array}{l}\text { (trial or multicentre or multicenter or multi centre or multi } \\
\text { center).ti }\end{array}$ & 189129 \\
\hline 15 & $\begin{array}{l}\text { (intervention? or controlled or control group? or (before adj5 } \\
\text { after) or (pre adj5 post) or ((pretest or pre test) and (posttest or } \\
\text { post test)) or quasiexperiment* or quasi experiment* or evaluat* } \\
\text { or effect? or impact? or time series or time point? or repeated } \\
\text { measur*).ti,ab }\end{array}$ & 7665787 \\
\hline 16 & (case study or case studies or case report?).mp. & 2076615 \\
\hline 17 & or/5-16 & 10387766 \\
\hline 18 & $\begin{array}{l}\text { exp animals/ or exp invertebrate/ or animal experiment/ or } \\
\text { animal model/ or animal tissue/ or animal cell/ or nonhuman/ }\end{array}$ & 20455540 \\
\hline 19 & human/ or normal human/ or human cell/ & 15246656 \\
\hline 20 & 18 and 19 & 15214361 \\
\hline 21 & 18 not 20 & 5241179 \\
\hline 22 & (systematic review or literature review).ti. & 58289 \\
\hline 23 & “cochrane database of systematic reviews”.jn. & 3772 \\
\hline 24 & or $/ 21-23$ & 5302667 \\
\hline 25 & 17 not 24 & 8154088 \\
\hline 26 & 4 and 25 & 242 \\
\hline 27 & limit 26 to embase & 136 \\
\hline
\end{tabular}

Interventions to reduce corruption in the health sector (Review) 


\section{Global Health (CABDirect)}

(de:corruption OR title:corruption OR title:corrupt OR title:“corruptive payment” OR title:"corruptive payments" OR title:bribe OR title:bribes OR title:bribery OR title:forgery OR title:fraud OR title:fraudulence OR title:fraudulent OR title:swindle OR title:swindling OR title:kickback OR title: "informal payment" OR title:"informal payments" OR ab:corruption OR ab:corrupt OR ab:"corruptive payment” OR ab:“corruptive payments” OR ab:bribe OR ab:bribes OR ab:bribery OR ab:forgery OR ab:fraud OR ab:fraudulence OR ab:fraudulent OR ab:swindle OR ab:swindling OR ab:kickback OR ab: "informal payment" OR ab: "informal payments") AND (randomis* OR randomiz* OR randomly OR trial OR intervention* OR control* OR "before AND after" OR pretest OR "pre test" OR posttest OR "post test" OR quasiexperiment* OR “quasi experiment” OR "quasi experiments" OR evaluat* OR effect* OR impact* OR "time series" OR "time point" OR “time points" OR measur* OR “case study" OR “case studies" OR "case report" OR "case report”) AND (sc:he)

\section{ABI/Inform Global (ProQuest)}

ALL((corruption or corrupt or fraud* or bribe or bribes or bribery or forgery or swindle or swindling or kickback* or informal N/0 pay* or corruptive N/0 pay*) N/6 (health* or medic* or hospital* or "primary care" or physician* or doctor* or general P/0 practitioner* or nurse* or pharmac*) N/6 (regulat* or law or laws or lawsuit* or legislat* or policy or policies or whistleblow* or whistle P/0 blow* or prevent* or reduc* or minimis* or minimiz* or transpare* or accountab* or discretion* or detect* or enforce* or surveillance or condition* or campaign* or watchdog* or agency or agencies or background N/0 check or background N/0 credit)) and ALL(randomis* or randomiz* or randomly or trial or intervention* or control* or before $\mathrm{P} / 5$ after or pretest or "pre test" or posttest or "post test" or quasiexperiment* or quasi P/0 experiment* or evaluat* or effect* or impact* or "time series" or "time point" or "time points" or repeated P/0 measur* or "case study" or "case studies" or "case report" or "case report")

\section{EconLit (ProQuest)}

$\mathrm{KW}=\left(\right.$ fraud ${ }^{*}$ or corrupt ${ }^{*}$ or bribe or bribes or bribery or forgery or swindle or swindling or kickback* or informal pay $\left.{ }^{*}\right)$ and $\mathrm{KW}=$ (health* or medic* or pharmac* or hospital* or primary care or physician* or doctor* or general practitioner* or nurse*)

\section{Sociological Abstract and Social Services Abstracts (ProQuest)}

$\left(\mathrm{KW}=\left(\right.\right.$ health* $^{*}$ or medic* or hospital ${ }^{*}$ or primary care or physician* or doctor* $^{*}$ or general practitioner* or nurse $\left.\left.^{*}\right)\right)$ and $((\mathrm{DE}=(\mathrm{Corruption}$ or Gift Giving or Fraud or Organizational Crime or White Collar Crime or Larceny or Offenses or Absenteeism)) or $(\mathrm{KW}=($ fraud* or corrupt* $^{*}$ or gift giving or bribe* or forgery* or absenteeism or unnecessary procedure* or quackery or nepotism or embezzlement* ${ }^{*}$ collusion or pilfering or extortion* or kickbacks or fals* within 3 information* or fee* within 3 splitt* or supplier induced demand* or gaming the system* or state capture or counterfeit or inducement*) ${ }^{*}$ or $\left(\mathrm{KW}=\right.$ (gratitude* $^{*}$ or in formal* or informal* or unofficial* or un official* or illegal or under the counter or unethical or fals*) within 3 (pay* or charg* or fee*)) or $\left(\mathrm{KW}=\left(\mathrm{fals} \mathrm{s}^{*}\right.\right.$ or dishonest) within 3 credential $^{*}$ ) or $(\mathrm{KW}=$ (overprovision or over provision or underprovision or under provision or overbilling or over billing or underbilling or under billing $))$ ) and $((\mathrm{DE}=($ Government Regulation or Regulation or Control or Social Control or Law or Law Enforcement or Legislation or Investigations (Law Enforcement) or Surveillance or Crime Prevention or Prevention or Detention or Imprisonment or Arrests or Sentencing or Punishment or Sanctions or Legislation or Public Policy or Policy or Government Policy Accountability or Discretion or Conditioning) ) or $(\mathrm{KW}=($ prevent* or regulat* or control or law* or lawsuit* or legislat* or policy or policies or punish* or penalty or penalties or whistleblow* or whistle blow* or reduc* or minimis* or minimiz* or anti corrupt* or anticorrupt* or transpare* or accountab* or discretion* or detect* or enforce* or surveillance or condition* or campaign* or watchdog* or agency or agencies)) or $\left(\mathrm{KW}=\left(\right.\right.$ background or credit) within $\left.\left.2 \operatorname{check}^{*}\right)\right)$

\section{Worldwide Political Science Abstracts (ProQuest)}

ALL(corruption or corrupt or fraud* or bribe or bribes or bribery or forgery or swindle or swindling or kickback* or informal N/ 0 pay* or corruptive N/0 pay*) and ALL(health* or medic* or hospital* or "primary care" or physician* or doctor* or general P/0 practitioner* or nurse* or pharmac*) and ALL(regulat* or law or laws or lawsuit* or legislat* or policy or policies or whistleblow* or whistle $\mathrm{P} / 0$ blow* $^{*}$ or prevent* or reduc* $^{*}$ or minimis* or minimiz* $^{*}$ or transpare* or accountab* or discretion* ${ }^{*}$ or detect* or enforce* $^{*}$ or surveillance or condition* or campaign* or watchdog* or agency or agencies or background N/0 check or background N/0 credit) and ALL(randomis* or randomiz* or randomly or trial or intervention* or control* or before $\mathrm{P} / 5$ after or pretest or "pre test" or posttest

Interventions to reduce corruption in the health sector (Review) 
or "post test" or quasiexperiment* or quasi P/0 experiment* or evaluat* or effect* or impact* or "time series" or "time point" or "time points" or repeated P/0 measur* or "case study" or "case studies" or "case report" or "case report")

\section{International Political Science Abstracts (IPSA) (EBSCO)}

TX ( (fraud* ${ }^{*}$ corrupt* or bribe or bribes or bribery or forgery or swindle or swindling or kickback* or informal N/0 pay*) ) AND TX ( (health* or medic* or hospital* or "primary care" or physician* or doctor* or general N/0 practitioner* or nurse*) )

\section{LILACS (VHL - iAH form)}

corrupt $\$$ or fraud $\$$ or bribe or bribes or bribery or forgery or swindle or swindling or kickback $\$$ or corrupcao $\$$ or corrupcion $\$$ or suborn\$ or soborn\$ or propina\$

\section{I. WHOLIS (Global Health Library)}

corrupt* $^{*}$ or fraud* or bribe or bribes or bribery or forgery or swindle or swindling or kickback* or (informal and pay*) (in All indexes)

\section{New York Academy of Medicine Library}

Keyword: corrupt OR Keyword: fraud

Limited to: collection: (“GREYLIT”)

\section{OpenGrey}

(corrupt* OR fraud* OR bribe OR bribes OR bribery OR forgery OR swindle OR swindling OR kickback* OR "informal payment" OR “informal payments") AND (health* OR medic* OR hospital* OR "primary care” OR physician* OR doctor* OR "general practitioner" OR "general practitioners" OR nurse*)

\section{I4. World Bank (Documents \& Reports)}

Searched in Title (Any words) for: fraud corruption bribery

Limited to the following topics:

- Governance

- Health, nutrition and population

- Poverty reduction

- Private sector development

- Public sector development

\section{I5. World Bank e-Library}

fraud* in Title OR fraud* in Abstract OR corrupt* in Title OR corrupt* in Abstract

\section{U4 Anti-corruption Resource Centre}

Browsed

\section{I7. Transparency International}

Browsed

\section{8. UNDP Oslo Governance Centre}

corruption

Interventions to reduce corruption in the health sector (Review) 


\section{Poverty Action Lab}

corruption

\section{International Initiative for Impact Evaluation (3ie)}

corruption OR corrupt OR “corruptive payment” OR “corruptive payments” OR bribe OR bribes OR bribery OR forgery OR fraud OR fraudulence OR fraudulent OR swindle OR swindling OR kickback OR kickbacks OR “informal payment” OR “informal payments"

\section{World Health Organization (WHO) International Clinical Trials Registry Platform (ICTRP)}

corrupt* OR fraud* OR bribe OR bribes OR bribery OR forgery OR swindle OR swindling OR kickback* OR informal payment OR informal payments - In the Title

OR

corrupt* OR fraud* OR bribe OR bribes OR bribery OR forgery OR swindle OR swindling OR kickback* OR informal payment OR informal payments - In the Condition

OR

corrupt* OR fraud* OR bribe OR bribes OR bribery OR forgery OR swindle OR swindling OR kickback* OR informal payment OR informal payments - In the Intervention

\section{ClinicalTrials.gov (NIH)}

corruption OR corrupt OR “corruptive payment” OR “corruptive payments” OR bribe OR bribes OR bribery OR forgery OR fraud OR fraudulence OR fraudulent OR swindle OR swindling OR kickback OR kickbacks OR “informal payment” OR “informal payments"

\section{EU Cordis (documents)}

Search all fields: corrupt* OR fraud* OR bribe OR bribes OR bribery OR forgery OR swindle OR swindling OR kickback*

\section{Appendix 2. Assessments of the certainty of evidence}

\section{Dissemination of information}

\begin{tabular}{|c|c|c|c|c|c|c|c|}
\hline $\begin{array}{l}\text { Number of } \\
\text { studies }\end{array}$ & Design & Risk of bias & Inconsistency & Indirectness & Imprecision & Other & Certainty (overall score) \\
\hline \multicolumn{8}{|c|}{ Outcome: corruption - attitudes of doctors towards pharmaceutical industry gifts } \\
\hline 1 & $\begin{array}{l}\text { One } n \\
\text { study }\end{array}$ & n-randomised & & $\begin{array}{l}\text { One small study } \\
\text { from Germany } \\
\text { Germany } 2008\end{array}$ & & & Low \\
\hline
\end{tabular}

\section{Improved detection and enforcement}

Interventions to reduce corruption in the health sector (Review) 


\begin{tabular}{|c|c|c|c|c|c|c|c|}
\hline $\begin{array}{l}\text { Number of } \\
\text { studies }\end{array}$ & Design & Risk of bias & Inconsistency & Indirectness & Imprecision & Other & Certainty (overall score) \\
\hline \multicolumn{8}{|c|}{ Outcome: overbilling (false or fraudulent claims) } \\
\hline 1 & Cross-sec & tional study & - & $\begin{array}{l}\text { One study from } \\
\text { South Korea } \\
\text { South Korea } \\
2007\end{array}$ & - & - & Very low \\
\hline \multicolumn{8}{|c|}{ Outcome: resource use (healthcare expenditures) } \\
\hline 1 & $\begin{array}{l}\text { Regressio } \\
\text { ing a prox } \\
\text { enforcem } \\
\text { tiple expl }\end{array}$ & $\begin{array}{l}\text { n analyses us- } \\
\text { xy measure for } \\
\text { ent with mul- } \\
\text { anatory factors }\end{array}$ & - & $\begin{array}{l}\text { One study from } \\
\text { the USA } \\
\text { USA } \\
1994-1998\end{array}$ & - & - & Very low \\
\hline \multicolumn{8}{|c|}{ Outcome: healthcare and health outcomes (utilisation and health outcomes) } \\
\hline 1 & $\begin{array}{l}\text { Regressio } \\
\text { ing a prox } \\
\text { enforcem } \\
\text { tiple expl }\end{array}$ & $\begin{array}{l}\text { n analyses us- } \\
\text { xy measure for } \\
\text { ent with mul- } \\
\text { anatory factors }\end{array}$ & - & $\begin{array}{l}\text { One study from } \\
\text { the USA } \\
\text { USA } \\
1994-1998\end{array}$ & $\begin{array}{l}\text { Wide confi- } \\
\text { dence intervals }\end{array}$ & - & Very low \\
\hline
\end{tabular}

Establishment of an independent agency and improved detection and enforcement

\begin{tabular}{|c|c|c|c|c|c|c|c|}
\hline $\begin{array}{l}\text { Number of } \\
\text { studies }\end{array}$ & Design & Risk of bias & Inconsistency & Indirectness & Imprecision & Other & $\begin{array}{l}\text { Certainty (over- } \\
\text { all score) }\end{array}$ \\
\hline \multicolumn{8}{|c|}{ Outcome: corruption - complaints and convictions } \\
\hline 1 & \multicolumn{2}{|c|}{$\begin{array}{l}\text { Post intervention data } \\
\text { only, case study without } \\
\text { a comparison }\end{array}$} & - & $\begin{array}{l}\text { One small study } \\
\text { from India } \\
\text { India } \\
2001-2005\end{array}$ & - & - & Very low \\
\hline \multicolumn{8}{|c|}{ Outcome: corruption - overbilling (false or fraudulent claims) } \\
\hline 1 & \multicolumn{2}{|c|}{$\begin{array}{l}\text { Regression analy- } \\
\text { sis using before-and-af- } \\
\text { ter data }\end{array}$} & - & $\begin{array}{l}\text { One study from } \\
\text { the USA } \\
\text { USA } \\
1993-2001\end{array}$ & - & - & Very low \\
\hline
\end{tabular}

Outcome: corruption - enforcement actions

Interventions to reduce corruption in the health sector (Review) 


\begin{tabular}{|c|c|c|c|c|c|c|}
\hline 1 & Postintervention data & - & $\begin{array}{l}\text { One study from } \\
\text { the USA } \\
\text { USA } \\
2005-2014\end{array}$ & - & $\begin{array}{l}\text { Very strong asso- } \\
\text { ciation }\end{array}$ & High \\
\hline
\end{tabular}

Outcome: resource use - amount collected and return on investment

\begin{tabular}{|c|c|c|c|c|c|c|}
\hline 1 & Postintervention data & - & $\begin{array}{l}\text { One study from } \\
\text { the USA } \\
\text { USA } \\
2005-2014\end{array}$ & - & $\begin{array}{l}\text { Very strong asso- } \\
\text { ciation }\end{array}$ & High \\
\hline \multicolumn{7}{|c|}{ Outcome: resource use - estimated programme savings } \\
\hline 1 & $\begin{array}{l}\text { The methods used to es- } \\
\text { timate the programme } \\
\text { savings are not clearly } \\
\text { described }\end{array}$ & $\begin{array}{l}\text { Substantial vari- } \\
\text { ation from year } \\
\text { to year }\end{array}$ & $\begin{array}{l}\text { One study from } \\
\text { the USA } \\
\text { USA } \\
2005-2014\end{array}$ & - & - & Low \\
\hline
\end{tabular}

Increased transparency and accountability

\begin{tabular}{|c|c|c|c|c|c|c|c|}
\hline $\begin{array}{l}\text { Number of } \\
\text { studies }\end{array}$ & Design & Risk of bias & Inconsistency & Indirectness & Imprecision & Other & Certainty (overall score) \\
\hline \multicolumn{8}{|c|}{ Outcome: corruption (informal payments) } \\
\hline 1 & \multicolumn{2}{|c|}{$\begin{array}{l}\text { Before-after data from } \\
\text { national surveys }\end{array}$} & - & $\begin{array}{l}\text { One study from } \\
\text { Kyrgyzstan } \\
\text { Kyrgyzstan } \\
2001-2010\end{array}$ & - & - & Low \\
\hline \multicolumn{8}{|c|}{ Outcome: corruption (pharmaceutical company spending on gifts) } \\
\hline 1 & \multicolumn{2}{|c|}{$\begin{array}{l}\text { Postintervention trends } \\
\text { using company disclo- } \\
\text { sure data }\end{array}$} & - & $\begin{array}{l}\text { One study from } \\
\text { the USA } \\
\text { USA } \\
2002-2006\end{array}$ & - & - & Very low \\
\hline \multicolumn{8}{|c|}{ Outcome: corruption (fraud) } \\
\hline 1 & \multicolumn{2}{|c|}{$\begin{array}{l}\text { One cross-sec- } \\
\text { tional study with } 20 \% \\
\text { response rate, multiple } \\
\text { comparisons }\end{array}$} & - & $\begin{array}{l}\text { One study from } \\
\text { the USA } \\
\text { USA } 2006\end{array}$ & - & - & Very low \\
\hline
\end{tabular}

Interventions to reduce corruption in the health sector (Review) 


\section{CONTRIBUTIONSOFAUTHORS}

All the review authors drafted and revised the protocol, performed article screening and data collection, and drafted and revised the review.

\section{DECLARATIONSOF INTEREST}

Rakhal Gaitonde: none known.

Andrew D Oxman: none known.

Peter O Okebukola: none known.

Gabriel Rada: none known.

\section{SOURCES OF SUPPORT}

\section{Internal sources}

- Community Health Cell Extension Unit, Society for Community Health Awareness Research and Action, Chennai, India.

- National Health Insurance Scheme, Nigeria.

- Norwegian Knowledge Centre for the Health Services, Oslo, Norway.

- Yaoundé Central Hospital, Cameroon.

\section{External sources}

- Norwegian Agency for Development and Cooperation (Norad), Oslo, Norway.

- The Effective Health Care Research Consortium which is funded by UK aid from the UK Government for the benefit of developing countries, UK.

\section{DIFFERENCES BETWEEN PROTOCOLANDREVIEW}

\section{Criteria for considering studies for this review}

We decided after the protocol was published, Gaitonde 2010, to exclude studies of interventions targeted at absenteeism, since this was the focus of another Cochrane review (Kiwanuka 2014).

\section{Assessment of risk of bias in included studies}

For randomised and non-randomised trials, interrupted time series (ITS) studies and controlled before-and-after (CBA) studies we intended to use standard Cochrane Effective Practice and Organisation of Care (EPOC) criteria for assessing the risk of bias (Cochrane EPOC 2015), and to assess the overall risk of bias as described in the Cochrane Handbook for Systematic Reviews of Interventions, Higgins 2011, for each main outcome (see the 'Types of outcome measures' section). However, we did not find any trials, ITS analyses or CBA studies that met our inclusion criteria.

Interventions to reduce corruption in the health sector (Review) 


\section{Measures of treatment effect}

For ITS studies, we intended to report the immediate effect after the specified transition period, at one year and, if reported, after longer periods of follow-up. We intended to measure the immediate effect of the intervention as the difference between the fitted value for the first postintervention data point (after the specified transition period) minus the predicted outcome based on the pre-intervention slope only. We intended to measure longer-term effects in the same way.

\section{Unit of analysis errors}

For cluster randomised trials and CBA studies we intended to control that an appropriate analysis had been done that adjusted for clustering in calculating measures of precision. If this had not been done, we intended to attempt to extract necessary data (intra-cluster correlation coefficients) or obtain these from the investigators, and to reanalyse the results. If this was not possible, we intended to report point estimates, but not the reported measures of precision.

\section{Dealing with missing data}

We intended to contact the study investigators to collect information that was missing from study reports, but we did not find this necessary.

\section{Data synthesis}

For the primary analysis, we intended to group included studies based on the type of corruption that they were intended to reduce (listed under the 'Data extraction and management' section). We did not anticipate that we would find multiple studies that were similar enough that it would be informative to calculate an overall effect size. If we did, we intended to calculate mean differences using a random-effects model.

\section{Subgroup analysis and investigation of heterogeneity}

Within each group of studies that evaluated interventions targeted at the same type of corruption (listed under the 'Data extraction and management' section), we intended to compare the impacts reported for similar outcome measures, if possible, using standardised measures of effect and testing for differences in mean differences across studies. We intended to consider the following explanatory factors with the indicated hypothesised directions of effect.

- Type of intervention (categories in Table 3): more restrictive or intensive interventions (listed from least to most restrictive or intensive in Table 3) lead to an increased effect.

- Risk of bias (low to high): higher risk of bias lead to an increased effect.

- Corruption Perceptions Index (continuous): more corruption lead to a decreased effect.

- World Bank country classification (low to high income): higher income lead to an increased effect.

We intended to undertake these analyses as hypothesis-generating and to interpret the results cautiously, since we anticipated that there would be a small number of studies with many differences in the settings, targeted populations, outcome measures and study designs. This was not possible in this review.

Interventions to reduce corruption in the health sector (Review) 


\section{INDEX TERMS}

\section{Medical Subject Headings (MeSH)}

${ }^{*}$ Health Care Sector [economics]; *Law Enforcement; Controlled Before-After Studies; Cross-Sectional Studies; Fraud [economics; legislation \& jurisprudence; *prevention \& control]; Germany; Guidelines as Topic; India; Kyrgyzstan; Reimbursement Mechanisms; Republic of Korea; Social Responsibility; United States

\section{MeSH check words}

Humans

Copyright ( 2016 The Authors. Cochrane Database of Systematic Reviews published by John Wiley \& Sons, Ltd. on behalf of The Cochrane Collaboration. 